\title{
PARA UN CONCEPTO DEL ESTADO SOCIAL DE DERECHO
}

\author{
Enzo Solari Alliende \\ Profesor de Introducción y Filosofía del Derecho \\ Universidad Católica del Norte \\ Sede Coquimbo
}

En este trabajo se pretende una conceptuación nítida del estado social de derecho, aunque somera y apoyada en la tradición pertinente. Para ello, se procederá en dos pasos: primero, procurando arribar a una definición del nudo estado de derecho, ya que éste es presupuesto del estado social, y luego, averiguando de diversos modos lo que formalmente pueda ser dicho estado social.

\section{EL ESTADO DE DERECHO}

El estado de derecho es un precipitado del pensamiento político y de la realidad política que tiene una prolongada tradición. A continuación, se revisarán algunos hitos de esta tradición -sin pretensión alguna de exhaustividad-, con el solo fin de obtener una conceptuación nítida del estado de derecho.

El estado de derecho cobra su perfil contemporáneo sólo a partir del siglo XVIII. Empero, el proceso de su formación es muy anterior. Es lo que se verá a continuación.

\subsection{La formación del estado de derecho}

Ya en el régimen político de los hebreos se advierte un primordio del estado de derecho. El estado israelita es un estado formalmente limitado. Aunque no hubo 'una' concepción israelita del estado, sí hubo "... una misma concepción del poder, que es fundamental para el pensamiento israelita, a saber, la teocracia: Israel es el pueblo de Yahveh y no hay otro señor más que él... Los jefes humanos de este pueblo son escogidos, aceptados o tolerados por Dios, pero le están subordinados y son juzgados conforme a su fidelidad a la alianza indisoluble concluida entre Yahveh y su pueblo"1. Así aparece, sólo por ejemplo, en Dt 17, 16-20 y en 2 R 9, 6. Loewenstein llega a decir que "el primer pueblo que practicó el constitucionalismo fueron los hebreos..." ${ }^{2}$, pues el régimen político de Israel "... se caracterizó... porque el dominador, lejos de ostentar un

\footnotetext{
El autor deja constancia de que estos apuntes -meros apuntes- corresponden a un trabajo llevado a cabo en 1993, salvo en el número 2.5 .

${ }^{1}$ DE VAUX, R., Instituciones del Antiguo Testamento (Herder, Barcelona 1964), pp. 147-149.

${ }^{2}$ LOEWENSTEIN, KARL, Teoría de la Constitución (Ariel, Barcelona-Caracas-México 1979), p. 154.
} 
poder absoluto y arbitrario, estaba limitado por la ley del Señor, que sometía igualmente a gobernantes y gobernados..." 3 .

Pero dentro del pensamiento antiguo, fue el griego el más importante.

Platón pensó bastante en la cuestión del ejercicio del poder. En La república postula que la mejor ciudad es aquélla donde los gobernantes son los que poseen el saber. "A menos... que los filósofos reinen en las ciudades o cuantos ahora se llaman reyes y dinastas practiquen noble y adecuadamente la filosofía, vengan a coincidir una cosa y otra, la filosofía y el poder político, y sean detenidos por la fuerza los muchos caracteres que se encaminan separadamente a una de las dos, no hay, amigo Glaucón, tregua para los males de las ciudades, ni tampoco, según creo, para los del género humano..." (473d $)^{4}$. No interesa, como se ve, el límite de tal gobierno: lo de veras interesante es que gobiernen los amigos de la sabiduría. Incluso más, pues mientras menos límites tengan estos gobernantes, tanto mejor será el gobierno de la sabiduría.

Sin embargo, Platón matizará estas ideas en El Político y Las Leyes ${ }^{5}$. En El Político no deja de creer que el gobierno de los amigos de la sabiduría es el mejor y que, por lo tanto, no ha de ceñirse a leyes (294a-b-c). Pero advierte: "atención, pues; siendo para nosotros la única acertada esa constitución que acabamos de citar, ¿sabes que las otras, por fuerza, si usan las leyes escritas de aquélla, entonces se conservan, haciendo lo que ahora está en vigencia, aunque no sea lo más justo?" (297d). ¿En qué consisten esas otras constituciones? "El que nadie en la polis se atreva a hacer cosa alguna contra las leyes, y quien se atreviere a ello, sea condenado a muerte y a las penas más severas. Y esta norma es la más justa y perfecta en segunda instancia, una vez se descartó la primera..." (297e). Así -excluyendo la recta constitución-, hay seis formas de gobierno, que se distinguen según si se gobierna según las leyes o contra las leyes (302e). "El caso es que, entonces, mientras andábamos buscando la forma de gobierno acertada, tal división no era precisa [la división del gobierno según ley y contra ley]...; mas, desde el momento que hemos separado aquélla, dejando las demás como inevitables, en éstas quedan ahora la ilegalidad y la legalidad como términos que dividen en dos cada una de ellas" (302e).

En Las Leyes se explicita todavía más lo que se ha dicho en El Político. El gobierno de los amigos de la sabiduría es imposible. "Es claro que si hubiera en algún caso un hombre que naciese por decreto divino con capacidad suficiente para tal desempeño, no tendría para nada necesidad de leyes que le rigiesen; porque no hay ley ni ordenación alguna superior al conocimiento, ni es lícito que la inteligencia sea súbdita o esclava de nadie, sino que ha de ser señora de todo si es verdadera inteligencia y realmente libre por naturaleza. Pero lo que ocurre es que tal cosa no se da absolutamente en ninguna parte sino en pequeña proporción; por ello se ha de escoger el otro término, la ordenación y la ley que miran a las cosas en general aunque no alcancen en particular a cada una de ellas" (875c-d). "... Es necesario que los hombres se den leyes y que vivan conforme a ellas o que, de lo contrario, en nada se diferenciarán de los animales

3 LOEWENSTEIN, KARL (n. 2), p. 154

4 PLATON, La República (trad, José Manuel Pabón y Manuel Fernández-Galiano, Alianza Editorial, Madrid 1990). Expresiones similares aparecen en 499 b y en El Político, 293c-d-e.

PLATON, El Político (trad. Antonio González Laso, Instituto de Estudios Políticos, Madrid 1955); Las Leyes (trad. José Manuel Pabón y Manuel Fernández-Galiano, Instituto de Estudios Políticos, Madrid 1960). 
más feroces; la razón de esto es que no se da naturaleza humana alguna que a un mismo tiempo conozca lo que conviene a los hombres para su régimen político y que, conociendo así lo mejor en ello, pueda y quiera constantemente ponerlo por obra" (874e875a). El gobierno de la ley constituye formalmente a la mejor ciudad posible. "... Pensemos que cada uno de nosotros, los seres vivos, somos marionetas de los dioses, fabricados ya para juguetes de ellos, ya con algún fin serio, pues esto último, en efecto, no lo conocemos: lo que sabemos es que esas afecciones, a manera de unas cuerdas o hilos interiores, tiran de nosotros y nos arrastran, siendo opuestas entre sí a acciones opuestas en la línea divisoria de la virtud y la maldad. En efecto, la razón nos dice que debemos seguir constantemente una sola de aquellas tensiones $y$, sin dejarla en manera alguna, tirar contra las otras cuerdas; y que esa tensión es la conducción del raciocinio, áurea y sagrada, que se llama ley general de la ciudad; que las otras son duras y férreas y sólo aquélla suave y uniforme como el oro, a diferencia de las demás, multiformes con varias apariencias" (644e-645a).

En Las Leyes, además, Platón piensa que el mejor de los gobiernos es el mixto, o sea, aquél donde se combinan varios tipos -idea de prolongada vigencia en la historia del pensamiento político-. "... Hay como dos regímenes-madres, de los cuales puede decirse acertadamente que nacen todos los demás; y al uno de ellos debemos llamarle monarquía y al otro democracia... Todos los demás regímenes presentan, como dije, variedad de matices de esos dos; y es fuerza que en algún modo participen de ambos, si ha de haber en ellos libertad y concordia concertadas con la razón; y esto es lo que trata de imponer nuestro argumento declarándonos que jamás, falta de estos elementos, podrá estar bien regida una ciudad" (693d-e). "Pues por haberse aficionado una de esas ciudades más de lo justo y exclusivamente a la monarquía, y la otra a la libertad, ninguna ha alcanzado la justa medida de estas cosas..." (693e) $)^{6}$.

Aristóteles, por su parte, siguió pensando estas cosas. La Política da cuenta de ello ${ }^{7}$. En primer término, Aristóteles cree-como Platón en Las Leyes- que el régimen mixto es el mejor de los regímenes posibles. "En las 'Leyes' se dice que el régimen mejor debe estar compuesto de democracia y tiranía, las cuales o no pueden considerarse en absoluto como regímenes, o son los peores de todos. Más razón tienen los que mezclan más: pues el régimen compuesto de más es mejor" (1266a). "Que el régimen intermedio es el mejor, es evidente, puesto que es el único libre de sediciones" (1296a) ${ }^{8}$. Agrega -también siguiendo a Platón- que la primacía de la ley es la nota característica de los buenos gobiernos. Así dice: "Pero respecto de la llamada monarquía absoluta, es decir, aquella en que el rey lo gobierna todo a su arbitrio, opinan algunos que no es natural que uno solo tenga soberanía sobre todos los ciudadanos cuando los que constituyen la ciudad son iguales; pues los que son iguales por naturaleza tienen necesariamente los mismos derechos y los mismos méritos fundados en la naturaleza... Por tanto, es justo gobernar y ser gobernados por igual, y que ambas cosas se hagan por turno. Esto ya implica una ley, puesto que el orden es una ley. Luego es preferible que la ley gobierne antes que uno cualquiera de los ciudadanos, y en virtud de la misma razón, aun en el caso de que sea mejor que gobiernen varios, éstos deben ser instituídos como

\footnotetext{
${ }^{6}$ Lo mismo en 701 e.

${ }^{7}$ ARISTOTELES, Política (trad. Julián Marias y María Araujo, Instituto de Estudios Políticos, Madrid 1970).

${ }^{8}$ Lo mismo en $1294 \mathrm{~b}$.
} 
guardianes y servidores de las leyes, pues es forzoso que haya magistrados, pero se afirma que no debe ser uno solo, al menos cuando todos son iguales" (1287a). Por último, Aristóteles hace una distinción en los cometidos de los gobiernos -que no coincide, por cierto, con la separación de poderes de Locke y Montesquieu-. "Todo régimen tiene tres elementos, y el legislador concienzudo debe considerar acerca de ellos lo que conviene a la república... De estos tres elementos, una cuestión se refiere a cuál es el que delibera sobre los asuntos de la comunidad; la segunda, a las magistraturas (esto es, cuáles deben ser y sobre qué asuntos deben tener autoridad y cómo debe verificarse su nombramiento), y la tercera, a la administración de justicia" (1297b-1298a).

El régimen político de los griegos encarnó, durante algún tiempo al menos, estas ideas. Loewenstein asegura que en Grecia se dio el mejor de los gobiernos constitucionales: la democracia constitucional, es decir, el gobierno popular sujeto a las leyes. "Todas las instituciones políticas de los griegos reflejan su profunda aversión a todo tipo de poder concentrado y arbitrario, y su devoción casi fanática por los principios del Estado de derecho de un orden... regulado democrática y constitucionalmente, así como por la igualdad y la justicia igualitaria" ${ }^{\text {? }}$.

Al historiar a Roma, Polibio continúa con la idea de que el mejor gobierno es el gobierno mixto. "Hay en la historia, cree Polibio, una ley inevitable de crecimiento y decadencia. Explica esto por la tendencia de todas las formas de gobierno no mixtas a degenerar en formas características... El motivo que explica la fortaleza de Roma consiste en que ésta había adoptado inconscientemente una forma mixta de gobierno en la cual los elementos se encuentran 'exactamente ajustados y en perfecto equilibrio'. Los cónsules constituyen un factor monárquico, el senado uno aristocrático y las asambleas populares uno democrático; pero el verdadero secreto del gobierno romano consiste en el hecho de que los tres poderes se frenan recíprocamente, impidiendo así la natural tendencia a decaer que se produciría en el caso de que alguno de ellos llegase a ser demasiado poderoso" 10 . Pensando también en Roma, Loewenstein ha dicho que su orden republicano "... presenta el ejemplo clásico de una sociedad estatal que siendo fundamentalmente constitucional, no cometió el error de una excesiva democratización" ${ }^{11}$. Hubo en Roma, dice, numerosos controles intraórganos e interórganos; más aún, existió el dogma de la 'lex regia', “... según el cual el dominio absoluto del monarca tenía su fuente originaria en la delegación del poder político del pueblo en el emperador"12 $^{12}$. Justo López, en cambio, asevera que en Roma no hubo un gobierno estrictamente constitucional. 'En la misma Roma imperial, la 'lex regia' indicaba que los emperadores no tenían poder originario, sino que lo recibían del pueblo; sin embargo, ello no implicaba atisbo alguno de Constitucionalismo. Lo que puede de algún modo tenerse como antecedente de Constitucionalismo es el equilibrio institucional logrado durante los dos últimos siglos del período republicano y, en particular, la distinción entre 'jus

\footnotetext{
${ }^{9}$ LOEWENSTEIN, KARL (n. 2), p. 155.

${ }^{10}$ SABINE, GEORGE, Historia de la teoría política (Fondo de Cultura Económica, México 1972), p.122.

${ }^{11}$ LOEWENSTEIN, KARL (n. 2), p. 156.

12 LOEWENSTEIN, KARL (n. 2), p. 157.
} 
publicum' y 'jus privatum', de acuerdo con la cual la actividad de los magistrados estaba sometida a la 'lex' $1{ }^{13}$.

Precisamente en el mundo latino, Cicerón prosigue con la reflexión acerca del gobierno de las leyes. Bajo la influencia estoica, dice en Las leyes: "Ya veis, pues, que la esencia de la magistratura está en el gobernar y disponer órdenes rectas, útiles y conformes a las leyes. Del mismo modo que las leyes gobiernan a los magistrados, así el magistrado gobierna al pueblo, y puede decirse en verdad que el magistrado es una ley con voz, y la ley un magistrado sin ella" (III, 2-3) . $^{14}$

Siglos después, Santo Tomás de Aquino pensó en las cuestiones del gobierno mixto, de los límites del poder y del derecho de resistencia. Sobre la base de su clasificación de las formas de gobierno en monarquía, aristocracia, oligarquía, democracia y tiranía (la peor de todas), dice: "hay, finalmente, un régimen que reúne todos los anteriores, y que es el mejor..." (I-II,95,4) ${ }^{15}$. ¿Cuál es este régimen? "La mejor constitución en una ciudad o nación es aquélla en que uno es el depositario del poder y tiene la presidencia sobre todos, de tal suerte que algunos participen de ese poder $y$, sin embargo, ese poder sea de todos, en cuanto que todos pueden ser elegidos y todos toman parte en la elección. Tal es la buena constitución política, en la que se juntan la monarquía por cuanto és uno el que preside a toda la nación-, la aristocracia -porque son muchos los que participan en el ejercicio del poder-y la democracia, que es el poder del pueblo, por cuanto éstos que ejercen el poder pueden ser elegidos del pueblo y es el pueblo quien los elige" (I-II, 105, 1). Ahora bien, el poder de los gobernantes siempre se encuentra con límites, esto es, nunca es absoluto: la ley divina, la ley natural, la ley humana, el bien común y la justicia son límites del gobierno. "... El príncipe está exento de la ley en cuanto a la fuerza coactiva". Pero "... el príncipe no está exento de la ley por lo que toca a su fuerza directiva, y debe cumplirla voluntariamente, no por coacción" (1-II, 96, 5). Por lo mismo, las leyes injustas no obligan en conciencia y las leyes contrarias a los mandatos de Dios no han de ser obedecidas $(I-I I, 96,4)$. Y en cuanto al derecho de resistencia al gobierno injusto, Santo Tomás lo aborda diversamente en sus escritos-Suma Teológica, Sobre el Reino y Sobre las Sentencias-, ora descartándolo, ora aceptándolo.

Inmediatamente posterior a Santo Tomás, Marsilio de Padua postula a la ley como límite del gobierno y como producto del pueblo (o sea, de todos los súbditos). Marsilio introduce una tonalidad democrática en lo que estima que es el mejor gobierno. "Hay, pues, dos géneros de la parte gobernante o gobierno, uno templado y otro viciado; llamo 'bien templado' a uno de ellos con Aristóteles..., a aquél en el que el príncipe gobierna mirando a lo útil a la comunidad según la voluntad de los súbditos, y 'viciado' llamo al que falla en esto" $(1, V I I I, 2)^{16}$. Más adelante agrega: "digamos, pues, mirando a la verdad y al consejo de Aristóteles... que el legislador o la causa eficiente primera y propia de la ley es el pueblo, o sea, la totalidad de los ciudadanos, o la parte prevalente de él..." $(I, X I I, 3)$. Y otra vez: "... digamos que, según la verdad y según la

\footnotetext{
13

3 JUSTO LOPEZ, MARIO, Introducción a los estudios políticos (Kapelusz, Buenos Aires 1971) 2, p. 19.

${ }^{14}$ CICERON, Las leyes (trad. Alvaro D'Ors, Instituto de Estudios Políticos, Madrid 1970).

${ }^{15}$ SANTO TOMAS DE AQUINO, Suma Teológica (trad. Fr. Carlos Soria, Fr. Alberto Colunga y Fr. Juan José Ungidos, Biblioteca de Autores Cristianos, Madrid 1956) 6.

${ }^{16}$ MARSILIO DE PADUA, El defensor de la paz (trad. Luis Martínez Gómez, Tecnos, Madrid 1989).
} 
opinión de Aristóteles..., el poder eficiente de instituir el gobierno o de su elección pertenece al legislador, o sea, a la totalidad de los ciudadanos..." (I, XV, 2). La ley, así como tiene raigambre democrática, es también un límite para el gobernante. Precisamente el título de un capítulo de El defensor de la paz es: "De la necesidad de dar leyes tomadas en sentido propísimo, y que ningún gobernante, por virtuoso y justo que sea, debe gobernar sin leyes" (I, XI). Y algunos capítulos más adelante agrega: "pero como el príncipe, por ser hombre, tiene su entendimiento y su apetito capaces de recibir otras formas [que la de la ley], como, por ejemplo, una falsa apreciación o un deseo perverso, o ambas cosas, en fuerza de las cuales ocurre que él obre de modo contrario a lo que prescribe la ley, por ello el príncipe respecto de esas acciones se hace mensurable por otro que tenga autoridad de medir y regular según la ley a él o a sus acciones transgresoras de la ley; de otro modo todo gobernante se tornaría despótico y la vida civil servil e insuficiente". "...Pero el juicio, el precepto y la ejecución de cualquier corrección del príncipe, según su demérito o transgresión, debe hacerse por el legislador o por alguno o algunos constituidos en autoridad para ello por el legislador... Conviene también por algún tiempo suspender el oficio del príncipe que ha de ser sancionado, por respeto, sobre todo, a aquél o a aquéllos que deberán juzgar su transgresión, no sea que por la pluralidad del gobierno se produzca en la comunidad un cisma, algarada o lucha, y porque no es juzgado en cuanto príncipe, sino en cuanto súbdito transgresor de la ley" (I, XVIII, 3).

Durante el absolutismo europeo continental -y sobretodo en Francia-, tomaron cuerpo las llamadas leyes fundamentales, verdaderos límites con los que, en ciertos ámbitos, se encontraron los monarcas. Debido a ellas, la monarquía absolutamente absoluta devino monarquía relativamente absoluta -o casi absoluta-. Para García Pelayo, constituyen verdaderas normas constitucionales ${ }^{17}$. Incluso en Inglaterra se habló de leyes fundamentales: más que conceptos jurídicos o leyes propiamente tales, eran principios imprecisos que se utilizaban polémicamente para la lucha política ${ }^{18}$. "Sin embargo, durante la época de los Tudores existe una tendencia que considera el 'common law'... como una especie de derecho fundamental con primacía sobre las normas emanadas del Consejo del rey y del Parlamento" ${ }^{19}$. Empero, las leyes fundamentales fueron elaboradas, en cuanto concepto jurídico, en Francia, siendo allí "... un cuerpo específico de derecho, tanto por su objeto, pues se refieren exclusivamente al ejercicio y transmisión de la prerrogativa real, como por su carácter formal, pues, a diferencia de las demás leyes, tienen un carácter inmutable, no pudiendo ser abolidas ni abrogadas por la decisión real..." ${ }^{20}$. Bravo Lira afirma que la idea de leyes fundamentales y de monarquía absoluta reglada apareció en Francia en los siglos XIV y XV -con Jean de la Terre, Claude de Seyssel, Bernard Girard, Innocent Gentillet y Jean Bodin- ${ }^{21}$, y que pervivió durante los siglos XVII y XVIII, hasta la revolución ${ }^{22}$. En 1608, Charles Loyseau

17 GARCIA PELAYO, MANUEL, Derecho Constitucional Comparado (Revista de Occidente, Madrid 1959), pp. 23-25.

${ }^{18}$ GARCIA PELAYO, MANUEL (n. 17), p. 23.

19 GARCIA PELAYO, MANUEL (n. 17), p. 23.

${ }^{20}$ GARCIA PELAYO, MANUEL (n. 17), pp. 23-24.

21 BRAVO LIRA, BERNARDINO, "Formación del Estado moderno: el Estado absoluto y leyes fundamentales en Francia", en Revista de Derecho. Universidad Católica de Valparaíso 9 (1985), pp. 12-22.

22 BRAVO LIRA, BERNARDINO (n. 21), p. 29. 
dijo que son tres las leyes que ha de obedecer el rey -o sea, las leyes fundamentales-: "son, a saber, las leyes de Dios, porque el príncipe no es menos soberano por ser súbdito de Dios; las reglas de justicia naturales y no positivas, porque se dijo más arriba, que lo propio del señorío público es ser ejercido por justicia y no por discreción; y, finalmente, las leyes fundamentales del Estado, porque el príncipe debe usar de la soberanía según la naturaleza propia de ella y en la forma y condiciones que ella está estableci$\mathrm{da}^{123}$. Estas leyes, entonces, "... constituyen un marco jurídico inviolable al cual debe ceñirse el rey en el ejercicio de su poder absoluto" 24 . Pero en el siglo XVIII las ideas de la llustración alteraron la conceptuación clásica de las leyes fundamentales ${ }^{25}$. "El concepto de leyes fundamentales de Montesquieu, como principios abstractos; el de [Jean Jacques] Burlamaqui, como pactos entre el pueblo y el gobernante, y el de [Emer] Vattel, como limitaciones impuestas al gobernante por la nación, son componentes básicos del pensamiento político de la llustración" ${ }^{26}$. Alemania, por fin, también conoció leyes fundamentales: la tratadística alemana "... desde el siglo XVII comienza a designar como 'leyes fundamentales del Imperio' una serie de pactos y capitulaciones entre el emperador y los estamentos..." 27 . En suma: la monarquía absoluta no desconoció la existencia de ciertos límites ${ }^{28}$.

En la España medieval hubo límites al poder real que sólo desaparecieron en los tiempos modernos. "En España, tras los concilios toledanos que se realizaron durante alrededor de tres siglos -entre el año 400 y el 701-, comenzó, a partir del siglo $X$ y como consecuencia de la lucha por la reconquista contra los moros, el otorgamiento de privilegios, fueros y cartas" ${ }^{\prime 2}$. Curiosamente, la desaparición de los límites al poder durante la modernidad coincidió con la reflexión -propicia al poder limitado-de la escolástica española tardía ${ }^{30}$.

Pero fue en Inglaterra donde la cuestión de los límites al poder tuvo el desarrollo institucional e intelectual más relevante. Por una parte, fueron sucediéndose diversos pactos y constituciones que hicieron del poder real un poder esencialmente limitado: la Carta magna (1215), la 'Petition of rights' (1628), el 'Agreement of the people' (1647), el 'Instrument of government' (1653), el 'Habeas corpus act' (1679) y el 'Bill of rights' (1689) -que canonizó la primacía de la ley por sobre el rey- ${ }^{31}$. Por la otra, hubo una serie de apologistas del poder limitado: John de Salisbury, Henry Bracton, John Fortescue, Richard Hooker, Edward Coke, James Harrington, John Locke ${ }^{32}$. Locke, por

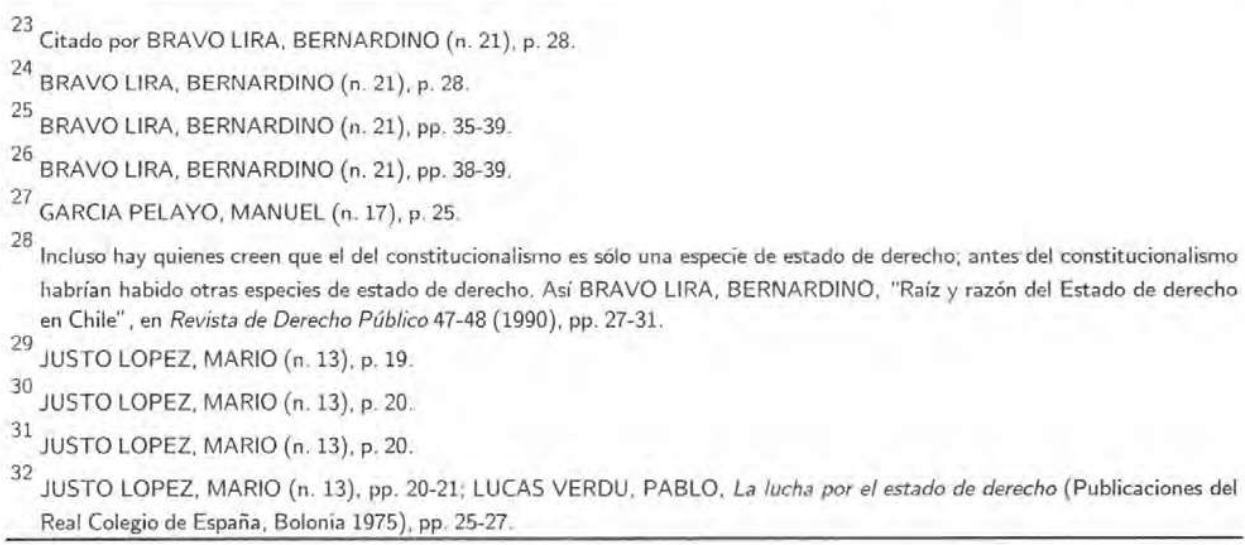


cierto, requiere especial atención. Pensó que el hombre tiene derechos en virtud de su propia naturaleza. "La razón... enseña a cuantos seres humanos quieren consultarla que, siendo iguales e independientes, nadie debe dañar a otro en su vida, salud, libertad o posesiones..." $(6)^{33}$ : tales son los derechos que naturalmente pertenecen a los hombres y que, como tales, no han de ser atropellados. Justamente los hombres entran en sociedad "... para la mutua salvaguardia de sus vidas, libertades y tierras..." (123), puesto que en el estado de naturaleza es muy inseguro el disfrute de estos bienes. No otro es el fin de la ley, del juez y del ejecutor (124-126). La sociedad política -dice Locke- debe fundarse en el consentimiento del pueblo y el gobernante que arrolla dicho principio es un tirano, contra el cual hay derecho de resistencia - jes la tradición medieval!- (199 y 202). Además, Locke ya distingue un poder legislativo, uno ejecutivo y uno federativo. El legislativo "... no es ni puede ser un poder absolutamente arbitrario sobre las vidas y los bienes de las personas" (135). "...No puede atribuirse la facultad de gobernar por decretos improvisados y arbitrarios; está, por el contrario, obligada [la potestad legislativa] a dispensar la justicia y a señalar los derechos de los súbditos mediante leyes fijas y promulgadas, aplicadas por jueces señalados y conocidos" (136). "El poder absoluto arbitrario o el gobernar sin leyes fijas establecidas, no pueden ser compatibles con las finalidades de la sociedad y del gobierno" (137). Aunque los poderes ejecutivo y federativo cumplen funciones diversas, normalmente están reunidos en un poder. Sin embargo, ambos poderes no deben confundirse con el legislativo: "... tampoco es conveniente... confiar la tarea de ejecutar las leyes a las mismas personas que tienen la misión de hacerlas. Ello daría lugar a que eludiesen la obediencia a esas mismas leyes hechas por ellos, o que las redactasen y aplicasen de acuerdo con sus intereses particulares, llegando por ello a que esos intereses fuesen distintos de los del resto de la comunidad..." (143). Locke, en fin, postula una soberanía restringida todavía no popular-, pero que no está demasiado lejos de la idea democrática. "Ningún hombre ni sociedad de hombres tiene poder para renunciar a su propia conservación, y por consiguiente, a los medios de conseguirla, entregando ese poder a la voluntad absoluta y a la soberanía arbitraria de otra persona... En ese sentido, puede afirmarse que la comunidad es siempre el poder supremo" (149).

En Francia, Montesquieu aseguró que la división del poder es la mejor garantía de la libertad y que su indivisión acarrea el despotismo. "Hay en cada Estado tres clases de poderes: el poder legislativo, el poder ejecutivo de los asuntos que dependen del derecho de gentes y el poder ejecutivo de los que dependen del derecho civil" ${ }^{34}$. "Cuando el poder legislativo está unido al poder ejecutivo en la misma persona o en el mismo cuerpo, no hay libertad porque se puede temer que el monarca o el Senado promulguen leyes tiránicas para hacerlas cumplir tiránicamente... Tampoco hay libertad si el poder judicial no está separado del legislativo ni del ejecutivo. Si va unido al poder legislativo, el poder sobre la vida y la libertad de los ciudadanos sería arbitrario, pues el juez sería al mismo tiempo legislador. Si va unido al poder ejecutivo, el juez podría tener la fuerza de un opresor... Todo estaría perdido si el mismo hombre, el mismo cuerpo de personas principales, de los nobles o del pueblo, ejerciera los tres poderes: el

\footnotetext{
33 LOCKE, JOHN, Ensayo sobre el gobierno civil (Aguilar, Madrid 1969).

${ }^{34}$ MONTESQUIEU, Del espíritu de las leyes (Sarpe, Madrid 1984) 1, p. 168.
} 
de hacer las leyes, el de ejecutar las resoluciones públicas y el de juzgar los delitos o las diferencias entre particulares" ${ }^{35}$.

Un último antecedente del estado de derecho es la escuela profana del derecho natural: con su pretensión de que la ley es la figura universal del derecho natural, preparó el camino para la idea del imperio de la ley -verdadera clave del estado de derecho y, tal vez, su elemento más antiguo- ${ }^{36}$.

En adelante, puede afirmarse que la del estado de derecho es una idea fundamentalmente constituida en sus elementos primordiales.

\subsection{La constitución del estado de derecho}

El constitucionalismo es el producto y la culminación de esta historia intelectual y política. Su origen más inmediato es la evolución política norteamericana y francesa de la segunda mitad del siglo XVIII ${ }^{37}$; más allá, su origen mediato es el prolongado desarrollo político inglés; pero, más lejos todavía, su origen pende de la historia secular de los límites del poder. Como movimiento político y jurídico que es, el constitucionalismo entremezcla la pasión de poder y la pasión de límites al poder, como se apreció a finales del siglo XVIII en Francia ${ }^{38}$.

¿Cuál es la relación entre constitucionalismo y estado de derecho? Como dice Justo López, el constitucionalismo afirma que el estado debe ser estado de derecho, de manera tal que éste es el núcleo y la finalidad del constitucionalismo ${ }^{39}$. Ambos recogen la historia de los límites del poder, con sus diversos elementos -sobretodo, imperio de la ley, división del poder, derechos del individuo- ${ }^{40}$.

\footnotetext{
${ }^{35}$ MONTESQUIEU (n. 34), p. 169.
}

36

DIAZ, ELIAS, Estado de Derecho y sociedad democrática (Taurus, Madrid 1981), p. 28; GARCIA PELAYO, MANUEL (n. 17). p. 157; CASCAJO, JOSE LUIS, "Consideraciones sobre el Estado de Derecho", en Revista de Estudios Politicos 189-190 (1973), p. 82

37 Así, la primera manifestación del constitucionalismo "...se encuentra en las Constituciones de las colonias americanas que se transformaron en Estados soberanos al rebelarse contra la Corona inglesa y, posteriormente, en la Constitución de la Unión en 1787. Casi inmediatamente, hasta el punto de que no sea exagerado admitir que hubo simultaneidad en el comienzo, se produce la otra notable manifestación del Constitucionalismo propiamente dicho a través de los documentos que sucesivamente se fueron sancionando durante el proceso de la Revolución Francesa: la Declaración de los derechos del hombre y del ciudadano de 1789; la Constitución de 1791; la Constitución de 1793; la Constitución de 1795 (año III) y la Constitución de 1799 (año VIII)": JUSTO LOPEZ, MARIO (n. 13), p. 21. Más en general, puede decirse que "los momentos clave del desarrollo del constitucionalismo en los siglos XVIII y XIX son, sumariamente indicados, los siguientes: la Guerra de Independencia americana y la adopción de la Constitución (1776-1787); la Revolución Francesa de 1789, seguida de numerosas experiencias constitucionales en Francia; las reformas realizadas en Prusia por el barón Stein (1806-1809); la Restauración en Francia (1814-1815); el establecimiento de una unión alemana (Bund) en 1818; la Revolución francesa de 1830, seguida por otra en Bélgica y demás países europeos; el famoso Report de Lord Durham en 1838, que llevó a la creación del Dominio del Canadá en 1876; y, finalmente, las revoluciones de 1848, incluida la abortada intentona alemana para conseguir a la vez unidad nacional y un gobierno constitucional"; FRIEDRICH, CARL, Gobierno constitucional y democracia. Teoría y práctica en Europa y América (Instituto de Estudios Políticos, Madrid 1975) 1, p. 76

38

En cuanto a los elementos socioeconómicos que están a la base del constitucionalismo, ver HAURIOU. ANDRE, Derecho Constitucional e Instituciones Politicas (Ariel, Barcelona-Caracas-México 1980), pp. $201-209$.

39 JUSTO LOPEZ, MARIO (n. 13), p. 17.

40

"Han pasado muchos siglos hasta que el hombre político ha aprendido que la sociedad justa, que le otorga y garantiza sus derechos individuales, depende de la existencia de límites impuestos a los detentadores del poder en el ejercicio de su poder... 
El constitucionalismo, aunque ligado a las revoluciones de fines del siglo XVIII, ha tenido una evolución que se extiende hasta la actualidad. Hauriou ha distinguido cuatro períodos en el constitucionalismo: 1789.

“- El que sucedió a la Independencia americana y a la Revolución francesa de

- El que siguió a las revoluciones francesas de 1830 y de 1848 .

- El que se produjo después de la primera guerra mundial...

- Por último, el que se desarrolla desde el fin de la segunda guerra mundial y que está en lo fundamental ligado con la descolonización del Tercer Mundo" ${ }^{41}$.

En Iberoamérica, los textos constitucionales -nótese: los textos constitucionalessufrieron la influencia de la constitución norteamericana de 1787 , de la española (o de Cádiz) de 1812, del constitucionalismo francés y, en general, del constitucionalismo europeo (lo que se aprecia, por ejemplo, en lo relativo al procedimiento contenciosoadministrativo $)^{42}$.

Asimismo, las ideas matrices del derecho administrativo contemporáneo también radican en el constitucionalismo -así, la sujeción de la administración a la ley, el control, la justiciabilidad y la responsabilidad de la administración, los derechos del administrado frente a la administración- ${ }^{43}$.

En la economía ocurre como en la política: las cosas han de disponerse de modo tal que se resguarde máximamente la autonomía e intangibilidad del individuo y se reduzca al estado al mínimo indispensable. "Las Constituciones liberales del siglo pasado no se hacían específicamente problema del sistema económico, pero sí establecían unos derechos y libertades (ante todo el derecho de propiedad, la libertad de contrata-

Con el tiempo se ha ido reconociendo que la mejor manera de alcanzar este objetivo será haciendo constar los frenos que la sociedad desea imponer a los detentadores del poder en forma de un sistema de reglas fijas -'la constitución'- destinadas a limitar el ejercicio del poder político. La constitución se convirtió asi en el dispositivo fundamental para el control del proceso del poder... La historia del constitucionalismo no es sino la búsqueda por el hombre político de las limitaciones al poder absoluto ejercido por los detentadores del poder, asi como el esfuerzo de establecer una justificación espiritual, moral o ética de la autoridad, en lugar del sometimiento ciego... En un sentido ontológico, se deberá considerar como el 'telos' de toda constitución la creación de instituciones para limitar y controlar el poder político": LOEWENSTEIN, KARL (n 2), pp. 149-150, Vid. HAURIOU, ANDRE (n. 38), pp. 198-199.

41 HAURIOU, ANDRE (n. 38), pp. 99-100.

42 COLOMER VIADEL, ANTONIO, Introducción al constitucionalismo iberoamericano (Ediciones de Cultura Hispánica, Madrid 1990), pp. 69-70.

43

"El Derecho Administrativo surgió como manifestación de las concepciones jurídicas de la Revolución francesa y como una reacción directa contra las técnicas de gobierno del absolutismo... Lo verdaderamente singular del régimen de Derecho público surgido de la Revolución, que se concreta... en el Derecho Administrativo, y lo que constituye la definitiva originalidad histórica de éste, es justamente ese cambio radical de concepción del sistema jurídico. La Administración es una creación abstracta del Derecho y no una emanación personal de un soberano y actúa sometida necesariamente a la legalidad, la cual, a su vez, es una legalidad objetiva, que se sobrepone a la Administración y no un mero instrumento ocasional y relativo de la misma, y por ello también tal legalidad puede ser invocada por los particulares mediante un sistema de acciones, expresión del principio de libertad que la Revolución instaura, y que revela cómo dicha legalidad viene a descomponerse en verdaderos derechos subjetivos": GARCIA DE ENTERRIA, EDUARDO y FERNANDEZ, TOMAS-RAMON, Curso de Derecho Administrativo (Civitas, Madrid 1988) 1, pp. 410 y 412. Ver además: GARCIA DE ENTERRIA, EDUARDO, "La lucha contra las inmunidades del poder en el Derecho Administrativo (poderes discrecionales, poderes de gobierno, poderes normativos)", en Revista de Administración Pública 38 (1962), pp. 161-166; OVIEDO. TARCISIO, "La responsabilidad del Estado frente al error judicial", en Revista de Derecho. Universidad Católica de Valparaiso 6 (1982). 
ción, la libertad de comercio y la seguridad jurídica) que -aun concebidos como derechos generales de la personalidad- tenían la función de crear las condiciones jurídicas ambientales para el desarrollo del sistema económico del alto capitalismo, sistema que, bajo el marco de dichas condiciones, era concebido como regulado por sí mismo a través del mecanismo del mercado y sin necesidad de ninguna intervención estatal salvo para eliminar alguna perturbación circunstancial o coyuntural. Dicho de otro modo: el Estado, mediante ciertos derechos constitucionalmente garantizados y ciertas disposiciones normativas tales como las referentes al sistema monetario y arancelario, creaba un orden objetivo para la acción económica de los particulares, pero sin accionar por sí mismo más que subsidiariamente. En resumen, el orden estatal y el orden económico eran considerados como dos sistemas de funcionamiento substancialmente independiente, cada uno orientado por sus propios fines y realizándose por la operación de leyes de distinta naturaleza (jurídicas en un caso, económicas en otro)" 44.

Pero si el contenido del estado de derecho radica en los postulados del constitucionalismo, su nombre preciso -estado de derecho o 'Rechtsstaat'- se debe a la iuspublicística alemana del siglo $\mathrm{XIX}$

El antecedente más importante de dichos publicistas alemanes fue Immanuel $\mathrm{Kant}^{46}$. Sin embargo, el nombre 'estado de derecho' sólo fue utilizado por Adam Müller en 1809, por Carl Welcker en 1813 y, luego, por Johann von Aretin y Robert von Mohl (en 1824 y 1829 , respectivamente) ${ }^{47}$. De todos ellos, von Mohl efectúa la reflexión más interesante. En la Alemania de von Mohl concurrian las exigencias liberales, las urgencias de la unificación nacional y un marcado reformismo; en tanto que, en los estados constitucionales del sur alemán, el ideal político del liberalismo constitucional era la monarquía constitucional. La reflexión de von Mohl pende de dicho liberalismo ${ }^{48}$. Von Mohl asegura que la forma del estado se sujeta a la visión que tiene cada pueblo de los fines de la vida humana. El estado de derecho es el de los pueblos que son conscientes de que la vida humana tiene este elevado fin: la "... formación, lo más racional y completa posible, de todas las fuerzas físicas y espirituales de que dispone el hombre", en palabras de von Mohl. Por eso dice que "el Estado de Derecho sólo puede tener este

44 GARCIA-PELAYO, MANUEL, "Consideraciones sobre las cláusulas económicas de la Constitución", en Estudios sobre la 45 Constitución española de 1978 (Libros Pórtico, Zaragoza 1979), pp. 29-30.

${ }^{5}$ Para una caracterización general de la publicística alemana del siglo XIX y parte del XX, ver PEREZ ROYO, JAVIER, "EI proyecto de constitución del derecho público como ciencia en la doctrina alemana del siglo XIX", en Revista de Estudios Políti$\cos 1$ (1978)

${ }^{46}$ PEREZ LUÑO, ANTONIO, Derechos humanos, Estado de Derecho y Constitución (Tecnos, Madrid 1984), p. 214. Este autor afirma que, en Kant, el estado es un medio que, a través del derecho, asegura la libertad (p. 215). Empero, Kant entiende la libertad al menos en dos sentidos: uno, la libertad en sentido liberal como la no injerencia de los demás y del estado en cada cual, y dos, la libertad en sentido democrático como la participación de los ciudadanos en la elaboración de las normas (pp. 215-216). La libertad, entonces, no sólo carece de un claro perfil, sino que además no posee una base empirica; es, más bien, una 'idea de la razón' (p. 216). Para Kant, el estado de derecho es un estado formal, independiente de la experiencia: "Immanuel Kant concibe, en efecto, el Estado de Derecho como Estado de razón, esto es, como la condición 'a priori" (exigencia universal de la razón) para una coexistencia libre a través del derecho, entendido, a su vez, como normatividad racional 'porque la razón constituye el único fundamento de cualquier posible legislación positiva " (p. 217). Estas ideas influyeron en Wilhelm von Humboldt (p. 219).

47 ABELLAN, JOAQUIN, "Liberalismo alemán del siglo XIX: Robert von Mohl", en Revista de Estudios Politicos 33 (1983), p. 127; PEREZ LUÑO, ANTONIO (n. 46), p. 219.

Para mayores datos sobre el contexto de von Mohl, ver ABELLAN, JOAQUIN (n. 47), pp. 123-125. 
fin: ordenar de tal manera la vida colectiva que cada uno de sus miembros sea apoyado y estimulado en grado máximo en el ejercicio y aprovechamiento de todas sus fuerzas, libre e integralmente" 49 . "El 'Rechtsstaat', en resumen, es para Mohl una conformación racional, fundada en la exigencia de libertad, que regula la vida humana no de manera ilimitada sino eliminando los obstáculos para el libre desarrollo de las fuerzas del individuo, lo cual implica una amplia actividad de apoyo y fomento" ${ }^{50}$. Así las cosas, la contraposición entre estado de derecho y estado de policía es falsa. El estado de derecho requiere policía. "¿Quién querría vivir y podría vivir en un Estado que sólo administrara justicia y ninguna ayuda de policía?", se pregunta von Mohl. "El Estado tiene que preocuparse tanto de la policía como del derecho". "La policía desarrolla el Estado de derecho al eliminar los obstáculos que se oponen al libre desarrollo del individuo" ${ }^{51}$. Por consiguiente, la idea kantiana que desecha el estado de policía y promueve un estado "... limitado a la seguridad de la libertad y de la propiedad de los ciudadanos" es rechazada por von Mohl. Para Kant, como para Humboldt, el estado "no tiene nada que ver con el bienestar y felicidad de los ciudadanos" ${ }^{52}$. En suma, el estado de derecho "... está marcado por los principios de la razón. Aspira a la libertad del ciudadano, contribuyendo a su fomento. Los límites de su actuación vienen también de la libertad del individuo, pero en una forma tal que deja al Estado una actividad conformadora del desarrollo de los individuos" 53 .

Después de von Mohl, hubo una serie de juristas alemanes que siguieron desarrollando los perfiles del estado de derecho. Entre otros, Friedrich Stahl, Lorenz von Stein, O. von Bahr, Rudolf Gneist, Otto Mayer, Otto von Gierke, Thoma, Gerber, Laband y Jellinek. Sus ideas medulares son las siguientes: el estado de derecho es un estado autolimitado por el derecho positivo o, de otro modo, es el estado que realiza sus fines legalmente, sometiendo a la administración y a la jurisdicción a la ley; permite a todo individuo el acceso a la jurisdicción para lograr el cumplimiento de sus derechos frente al ejecutivo; $y$, por fin, contempla tribunales administrativos independientes ${ }^{54}$.

Ya en este siglo, no puede dejar de mencionarse el pensamiento de Hans Kelsen Afirma Kelsen, ciñéndose estrictamente a su comprensión del derecho, que todo estado es un estado de derecho, por cuanto el estado es como la personificación del sistema jurídico en su conjunto. Admite, sin embargo, un concepto más restringido de estado de derecho, en abierta concesión a la tradición que he reseñado. Tal cosa se puede advertir en las citas que siguen. "... El Derecho no es, como se afirma, un contenido peculiar [del Estado], sino la forma del orden estatal, o mejor, este mismo orden con todos sus posibles contenidos; no hay fin alguno que el Estado pueda perseguir si no es en la forma del Derecho..." ${ }^{55}$. Por tanto, toda antítesis entre estado de derecho y estado de poder es falsa. "Un criterio positivista, que no trate de elevar el derecho a la categoría absoluta de Derecho Natural, tiene que considerar el Estado como una especie

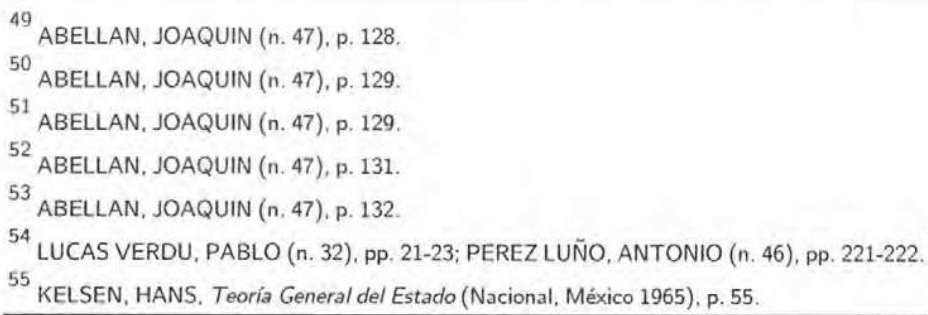


de rey Midas, que convierte en Derecho cuanto toca. Por esta razón, desde el punto de vista del positivismo jurídico, todo Estado es un Estado de Derecho, en el sentido de que todos los actos estatales son actos jurídicos, porque y en tanto que realizan un orden que ha de ser calificado de jurídico" 56 . "Ahora bien; por Estado 'de Derecho' no entendemos nosotros un orden estatal con un contenido específico (por tanto, no un Estado con ciertas y determinadas instituciones jurídicas, tales como la legislación democrática, la sujeción de los actos ejecutivos del jefe del Estado al refrendo del ministro responsable, la libertad política y civil de los ciudadanos, la independencia del poder judicial, la jurisdicción contencioso-administrativa, etc., es decir, un Estado de Derecho en sentido técnico), sino un Estado cuyos actos son realizados en su totalidad sobre la base del orden jurídico. Este concepto formal del Estado de Derecho es un concepto primario frente al concepto material del mismo, ya señalado. Pero desde un punto de vista estrictamente positivista, incompatible con todo género de Derecho natural, todo Estado tiene que ser Estado de Derecho en este sentido formal, puesto que todo Estado tiene que constituir un orden, un orden coactivo de la conducta humana, y este orden coactivo, sea cualquiera el método -autocrático o democrático- de su creación y cualquiera que sea su contenido, tiene que ser un orden jurídico que se va concretando gradualmente desde la norma fundamental hipotética hasta los actos jurídicos individuales, a través de las normas generales ${ }^{157}$. Como se ve, Kelsen es tan fiel a sus ideas como sensible a la tradición del estado de derecho.

¿Y cuál fue la actitud de la doctrina jurídica chilena ante esta tradición? En el siglo $\mathrm{XIX}$ los administrativistas y los constitucionalistas chilenos no hicieron mención alguna del estado de derecho, salvo tangenciales referencias de José Victorino Lastarria en su obra Elementos de derecho público constitucional (del año 1840$)^{58}$. En la primera mitad del siglo $X X$, sólo aludieron al estado de derecho los administrativistas Juan Antonio Iribarren (en 1936). Ernesto Merino (en 1936) y Manuel Jara (en 1936), aunque antes hubo atisbos en Valentín Letelier (en 1896). Y entre los constitucionalistas, Rafael Raveau (en 1939) ${ }^{59}$. Sólo en la segunda mitad de este siglo los autores chilenos comenzaron a acoger profusamente la idea del estado de derecho.

Por lo que toca a la enseñanza social de la Iglesia Católica contemporánea, puede decirse que el tema de los límites del poder no ha llamado su atención. Las referencias a esta cuestión escasean y carecen de mayor riqueza. En Pacem in terris se alude a los límites del poder, como se ve en las siguientes citas. "Consideremos.. que corresponde a las exigencias más íntimas de la misma naturaleza del hombre una organización jurídico-política de las comunidades humanas que se funde en una conveniente división de los poderes, en correspondencia con las tres funciones específicas de la autoridad pública. En ellas, en realidad, la esfera de la competencia de los poderes públicos se define en términos jurídicos, y en términos jurídicos están también reglamentadas las relaciones entre simples ciudadanos y funcionarios. Es razonable pensar que esto constituye un elemento de garantía y de protección en favor de los ciudadanos, en

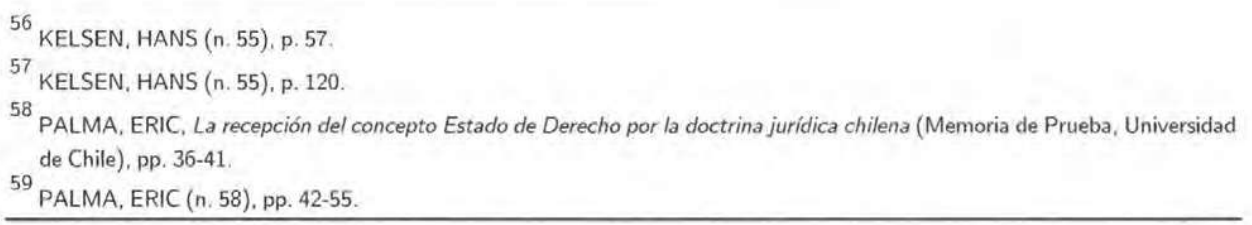


el ejercicio de sus derechos y en el cumplimiento de sus deberes" $(68)^{60}$. "Sin embargo, a fin de que la aludida organización político-jurídica de las comunidades humanas aporte las ventajas que le son propias, es indispensable que los poderes públicos ejerzan su competencia ordinaria y resuelvan los problemas extraordinarios con la aplicación de métodos y medios aptos, acomodados al cumplimiento de sus funciones y al nivel de desarrollo al que la organización de la sociedad ha llegado. Esto lleva consigo también que el poder legislativo, en el incesante cambio de situaciones, se mueva siempre en el ámbito del orden moral y de las normas constitucionales, e interprete objetivamente las exigencias del bien común; que el poder ejecutivo aplique las leyes con prudencia y pleno conocimiento de las mismas, y dentro de una valoración serena de los casos concretos; que el poder judicial administre la justicia con imparcialidad, inflexible frente a las presiones de intereses de parte, cualesquiera que sean. Esto trae consigo, además, que los ciudadanos y las entidades intermedias, en el ejercicio de sus derechos y en el cumplimiento de sus deberes, gocen de una tutela jurídica eficaz, lo mismo en las mutuas relaciones que frente a los funcionarios públicos" (69). "En la organización jurídica de las comunidades políticas se descubre en la época moderna, antes que nada, la tendencia a redactar en fórmulas concisas y claras una carta de los derechos fundamentales del hombre, que no es raro ver incluida en las Constituciones formando parte integrante de ellas" (75). "En segundo lugar se tiende también a fijar en términos jurídicos, no raramente por medio de la compilación de un documento llamado Constitución, los procedimientos para designar los poderes públicos, como también sus recíprocas relaciones, las esferas de sus competencias, los modos y métodos según los cuales están obligados a proceder" (76). "Se exige, finalmente, que de modo particular se establezcan en términos de derechos y deberes las relaciones entre los ciudadanos y los poderes públicos, y se atribuya a estos mismos poderes, como su papel principal, el reconocimiento, el respeto, el mutuo acuerdo, la eficaz tutela, el progreso continuo de los derechos y de los deberes de los ciudadanos" (77). Casi veinte años después, Centesimus Annus dice: ".... es preferible que un poder esté equilibrado por otros poderes y otras esferas de competencia, que lo mantengan en su justo límite. Es éste el principio del 'Estado de derecho', en el cual es soberana la ley y no la voluntad arbitraria de los hombres" $(44)^{61}$. Más aún, la Iglesia aprecia la democracia, con la prevención de que "una auténtica democracia es posible solamente en un Estado de derecho y sobre la base de una recta concepción de la persona humana" $(46)^{62}$.

Más en general, el tratamiento contemporáneo de la idea del estado de derecho es vastísimo, puesto que se mueve dentro de una idea ya más o menos constituida. Antes de exponer el perfil del estado de derecho, se consignan unas pocas caracterizaciones que a su respecto se han realizado, para así acometer en mejor pie aquella tarea.

Heller afirma que el estado de derecho supone una organización democrática, la división de los poderes, la garantía de los derechos fundamentales y la limitación del poder estatal mediante preceptos constitucionales - de modo de asegurar una suma de

60

61

1 JUA

XXIII, Pacem in terris, en Encíclicas Sociales (Paulinas, Santiago de Chile) 2

${ }^{2}$ Ver, además, LEON XIII, Rerum Novarum, en Encíclicas Sociales (Paulinas, Santiago de Chile) 1, número 46; y CONCILIO VATICANO II, Gaudium et Spes, en Concilio Vaticano II. Documentos completos (Paulinas, Bogotá 1987), números 73-75. 
libertades a los ciudadanos- ${ }^{63}$. Del Vecchio dice que el estado de derecho es aquél que obra bajo la forma de la ley, ley que debe recoger los derechos naturales del hombre; por ende, el estado de derecho -a diferencia del estado absoluto- tiene como ejes a la soberanía de la ley, el derecho de los ciudadanos de participar en la formación de la ley y la igualdad de aquéllos ante ésta ${ }^{64}$. Bobbio cree que el estado de derecho es el del gobierno de las leyes -y no de los hombres-, o sea, el gobierno sub-lege y per-lege ${ }^{65}$. Hauriou postula que el estado de derecho se asienta en la sumisión del poder estatal al derecho, la existencia de normas jurídicas superiores, el reconocimiento del individuo como fin de la polis, la presencia de censores de los gobernantes, el carácter representativo de las instituciones, la separación de poderes y la organización de elecciones libres para designar a los gobernantes y a sus censores; en tanto que la culminación jurídica del estado de derecho es el establecimiento de constituciones escritas, y su culminación política, la democracia occidental ${ }^{66}$. Para Loewenstein, el estado constitucional o de derecho se basa en la limitación y el control del poder estatal, de tal modo que sus elementos son la diferenciación de funciones estatales y su asignación a distintos órganos, la cooperación entre los órganos estatales, la proscripción de la voluntad autocrática de un órgano estatal como modo de solución de los conflictos entre los diversos órganos del estado, la mutabilidad pacífica del orden sociopolítico a través de la reformabilidad constitucional -excluyendo el uso de la fuerza o la ilegalidad- $y$, por último, el aseguramiento de una zona de autonomia e intangibilidad individual constituida por los derechos y libertades fundamentales ${ }^{67}$. García Pelayo considera que los elementos del estado de derecho son los siguientes: el reconocimiento de derechos individuales, una organización del poder estatal por la cual éste se limite a sí mismo y proteja la vigencia de aquellos derechos (así, habrá división de poderes y otros mecanismos) y la sumisión del poder estatal a normas jurídicas -que es lo que, en propiedad, define al estado de derecho- ${ }^{68}$. Garrorena propone los siguientes presupuestos del estado de derecho: la proclamación y garantía de la dignidad y de la libertad naturales del individuo; la limitación racional del poder por intermedio del derecho, tanto a través de su distribución equilibrada entre distintos titulares como de la elección de al menos un titular desde la base social; y, al fin, la primacía de la ley, verdadera expresión de la voluntad general ${ }^{69}$. Pérez Luño dice que, en un sentido ideológico, el estado de derecho posee una raigambre iusnaturalista $y$, por tanto, ha de satisfacer las exigencias de justicia material y de certeza; pero que, en su acepción técnica, comporta la vigencia del principio de legalidad, la garantía de derechos públicos subjetivos y el control judicial del estado ${ }^{70}$. Entrena Cuesta dice que el estado de derecho es "... aquella forma de Estado en que se reconocen y tutelan los derechos públicos subjetivos de los ciudadanos [éste es el elemento de fondo] mediante el sometimiento de la Administración a la

LER, HERMANN, Teoría del Estado (Fondo de Cultura Económica, México 1942), pp. 275-276.

${ }^{64}$ DEL VECCHIO, GIORGIO, Filosofía del Derecho (Bosch, Barcelona 1974), pp. $452-453$.

${ }^{65}$ BOBBIO, NORBERTO, Fundamento y futuro de la democracia (Edeval, Valparaíso), pp. 44-45.

${ }^{66}$ HAURIOU, ANDRE (n. 38), pp. 209- 408.

${ }^{67}$ LOEWENSTEIN, KARL (n, 2), pp. 150-154.

${ }^{68}$ GARCIA PELAYO, MANUEL (n. 17), p. 144

${ }^{69}$ GARRORENA, ANGEL, El Estado español como Estado social y democrático de Derecho (Tecnos, Madrid 1984), pp. 159160 .

${ }^{70}$ PEREZ LUÑO, ANTONIO (n. 46), pp. 238-243. 
Ley [éste es el elemento de forma]" ${ }^{71}$. Legaz y Lacambra sentencia que el estado de derecho responde a una concepción personalista y que requiere los siguientes elementos: un orden jurídico jerárquicamente estructurado, al que toca una primacía de la ley como norma general; los derechos humanos fundamentales; un fuero de la personalidad jurídica, que permita en especial reconocer derechos del individuo frente al estado; un sistema de responsabilidad de la administración y de recursos contenciosoadministrativos; y -aunque esto ya no es esencial- el control jurisdiccional de la legislación ${ }^{72}$. Lucas Verdú pretende que el estado de derecho supone la primacía de la ley, a cuyo imperio se sujeta la acción estatal; un sistema jerárquico de normas; la legalidad de la administración -con los recursos correspondientes-; la separación de poderes; el reconocimiento de la personalidad jurídica del estado; la garantía de los derechos fundamentales; $y$-a veces- el control de constitucionalidad de las leyes ${ }^{73}$. Elías Díaz, por su parte, incluye el imperio de la ley emanada de la voluntad general -lo que acarrea la primacía de la ley fundamental y el control de constitucionalidad de las leyes-; la división del poder estatal en poder legislativo, poder ejecutivo y poder judicial; la legalidad de la administración - por lo cual ha de haber control jurisdiccional y responsabilidad de ésta-; y la garantía y realización de los derechos fundamentales del hombre ${ }^{74}$. Vanossi presenta los siguientes elementos del estado de derecho: "... soberanía popular, creación del derecho por intervención o representación de los gobernados, predominio del consenso sobre la coerción en la gestión de las decisiones políticas fundamentales, separación y distribución de poderes, limitación y control del poder, independencia del controlante respecto del controlado, libertades individuales y derechos sociales, pluralismo de partidos (ideas) y de grupos (intereses), posibilidad permanente de alternancia en el acceso al poder, responsabilidad de los gobernantes, régimen de garantías y relativización de los dogmas oficiales" ${ }^{\prime 75}$. Lautaro Ríos reduce los elementos del estado de derecho a cinco: soberanía popular, división y equilibrio de los poderes, reconocimiento de los derechos fundamentales, responsabilidad del estado y control judicial de la administración ${ }^{76}$. Por último, Justo López distingue entre la finalidad del estado de derecho -constituida por la dignidad del hombre-, sus medios principistas -la soberanía popular y el imperio de la ley- y sus técnicas jurídicas -la supremacía constitucional y de la declaración de derechos, la distinción entre poder constituyente y poderes constituidos, la división orgánica y funcional entre los poderes constituidos, la independencia del poder judicial, la designación por elección de los titulares del poder constituyente y de los poderes constituidos (mediante competencia pacífica normativamente regulada), la

71 ENTRENA CUESTA, RAFAEL, "Notas sobre el concepto y clases de Estado de Derecho", en Revista de Administración Pública 33 (1960), p. 36. Este autor cita la opinión de Rozmaryn acerca de los componentes del estado de derecho, a saber: derechos fundamentales; reglas juridicas estables, coherentes y generales que vinculen al poder estatal; magistratura independiente, estable y sujeta a reglas generales; debido proceso garantizado; actuación administrativa conforme a las reglas jurídicas; 72 control judicial, desde el punto de vista juridico, de la administración (pp. 33-34).

72 LEGAZ Y LACAMBRA, LUIS, Humanismo, Estado y Derecho (Bosch, Barcelona 1960), pp. 77-82.

${ }^{73}$ LUCAS VERDU, PABLO (n. 32), pp. 23-24.

74 DIAZ, ELIAS (n. 36), pp. $31-42$.

75 VANOSSI, JORGE REINALDO, El Estado de Derecho en el constitucionalismo social (EUDEBA, Buenos Aires 1982), pp. 2-3. 76

RIOS, LAUTARO, "EI Estado de Derecho", en Revista de Derecho. Universidad Católica de Valparaíso 6 (1982), pp. 75-80. 
legalidad administrativa, el control de la actividad de los órganos estatales y la institucionalización de la oposición- ${ }^{77}$.

\subsection{Los elementos del estado de derecho}

Como pudo verse, la historia del estado de derecho es primordialmente la historia de los límites del poder. Esta historia tiene capítulos antiguos, medievales y modernos, y su culminación es el liberalismo: la historia de los límites del poder culmina en el liberalismo, puesto que el estado de derecho propiamente tal es una creación liberal. Sin embargo, dicha historia no terminó allí.

Casi paralelamente, fue desarrollándose la historia del gobierno popular, que es la historia misma de la democracia. Sus hitos son la Atenas de Pericles, ciertos filones del pensamiento medieval, algunas ciudades medievales y las ideas de Rousseau. Sólo después de Rousseau esta tradición vino a encontrarse con la de los límites del poder.

Bobbio ha dicho que recién desde las revoluciones americana y francesa el principio liberal y el democrático se hicieron inseparables: el liberalismo de Locke y la idea democrática de Rousseau sólo se abrazan con John Stuart Mill, que ya es liberal y demócrata ${ }^{78}$. Por esto es por lo que el estado de derecho de los dos últimos siglos es un estado democrático, de guisa que el del gobierno popular es ya un principio del estado de derecho.

Considerando su faz democrática, ahora sí se puede hacer un elenco de los elementos del estado de derecho:

a) la sujeción a la ley de individuos y grupos y, sobretodo, de los órganos del poder público, para lo cual es indispensable el control de dichos órganos y la posibilidad de pesquisar su responsabilidad ${ }^{79}$;

b) la división del poder público en diversos órganos que desarrollan preponderantemente una función -sea gubernamental y administrativa, sea legislativa, sea judicial-, de modo que cada uno de ellos esté dotado -dentro del ámbito de sus quehaceres- de una relativa independencia;

c) la garantía de ciertos derechos del hombre, que le aseguren alguna intangibilidad ante los demás y ante el poder;

d) el acceso al poder de cualquiera -en principio-, a través de elecciones competitivas y relativamente periódicas, caracterizadas por el sufragio universal y el predominio de la mayoría; y

e) la legitimidad de ideologías y de grupos que discrepen de los detentadores del poder y de la ideología dominante, de suerte que haya pluralismo en lo que hace a las ideas y a las agrupaciones.

\footnotetext{
77 JUSTO LOPEZ, MARIO (n. 13), p. 8.

78 BOBBIO, NORBERTO (n. 65), pp. 42-43.

79 Ver OVIEDO, TARCISIO (n. 43); PIERRY, PEDRO, "Control del acto administrativo. Recursos administrativos. Recurso contencioso administrativo", en Revista de Derecho. Universidad Católica de Valparaíso 4 (1980), pp. 239-240; OELCKERS, OSVALDO, "El principio de legalidad como supuesto de la potestad administrativa", en Revista de Derecho. Universidad Católica de Valparaiso 1 (1977), pp. 112-113.
} 


\section{EL ESTADO SOCIAL DE DERECHO}

Habiéndose arribado ya a un concepto de estado de derecho, se hará ahora lo propio con el estado social de derecho. Para ello, se expondrán las ideas de diversos autores acerca de las raíces y los significados de esta expresión, luego se hará una breve incursión en la doctrina cristiana y, finalmente, se reseñarán los contornos del estado social en dos constituciones contemporáneas. Así se podrá presentar, con la claridad que sea posible, los elementos del estado social de derecho.

\subsection{La formación del estado social de derecho}

La del estado social de derecho es una idea aún en formación. Es posible encontrar sus antecedentes más próximos en el siglo pasado.

Sin embargo, se pueden pesquisar sus rastros desde muy antiguo, porque la idea de que las condiciones materiales de la vida social incumben a los detentadores del poder y de que, correspondientemente, los miembros de la sociedad pueden aspirar a una cierta actividad de dichos detentadores en lo que se refiere a aquellas condiciones, es una idea persistente. Con dos ejemplos se ilustrará esto. En el pueblo hebreo hubo, entre otras, una institución que da cuenta de la idea señalada, Ilamada año jubilar. "La alienación de los bienes de familia y el desarrollo del préstamo a interés tenían como consecuencia el aumento del pauperismo y la servidumbre de los deudores insolventes o de sus fiadores. Así se destruía la igualdad social que había existido en los tiempos de la confederación de las tribus y que seguía siendo un ideal. Para poner medio a estos daños, la legislación religiosa ideó dos instituciones: el año sabático y el año jubilar" ${ }^{80}$. ¿Qué es el año jubilar? "En Lev 25, las prescripciones relativas al año sabático están reunidas con las referencias al año jubilar, Lev 25, 8-17.23-25... Tenía lugar cada cincuenta años, al expirar siete semanas de años. Era una franquicia... de todos los habitantes del país. Las tierras quedaban en reposo, cada cual volvía a entrar en posesión de su patrimonio, es decir, los campos y las casas que se habían enajenado volvían a su primitivo propietario... Por consiguiente, las transacciones inmobiliarias debían hacerse calculando los años que seguirían hasta el próximo jubileo: no se compraba el terreno, sino cierto número de cosechas. En fin, los deudores insolventes, los esclavos israelitas eran liberados; consiguientemente, el precio de rescate de estos esclavos se calculaba según el número de años que separaban el próximo jubileo. Se dan razones religiosas de estas medidas: la tierra no se puede vender con pérdida de derecho, ya que pertenece a Dios; los israelitas no pueden ser reducidos a esclavitud perpetua porque son servidores de Dios, que los hizo salir de Egipto" ${ }^{11}$. Empero, "... no existe el menor indicio de que alguna vez fuese practicada la ley... La ley del jubileo aparece, pues, como proponiendo un ideal de justicia y de igualdad social que no se realizó jamás" ${ }^{82}$.

Un segundo ejemplo, ya medieval, lo suministra Santo Tomás de Aquino en su opúsculo Sobre el Reino, pues encomienda al rey la procura de condiciones materiales mínimas en la vida social, condiciones que son indispensables para que el pueblo prac-

${ }^{80}$ DE VAUX, R. (n. 1), p. 244 ,

${ }^{81}$ DE VAUX, R. (n. 1), pp. 246-247.

${ }^{82}$ DE VAUX, R. (n. 1), p. 247. 
tique la virtud ${ }^{83}$. "Una vez instruído el Rey en la ley divina, debe cifrar todo su empeño en que viva virtuosamente el pueblo que está bajo su mando; lo cual lo conseguirá cumpliendo con las tres normas siguientes, a saber: tratando, en primer lugar, de establecer en el pueblo este modo de vivir según la virtud; procurando en segundo lugar conservar en el mismo pueblo esta manera virtuosa de vivir; y tratando, en fin, de fomentar la vida virtuosa.

Para que un hombre pueda vivir bien o como es debido se requieren dos cosas, siendo el primer requisito que viva según la virtud, pues por la virtud consigue el hombre llevar una vida buena; mientras que la segunda condición o requisito para que el hombre viva bien, es más bien secundaria y como instrumental, a saber, que el hombre disponga de los bienes temporales suficientes para las obras de virtud.

... Por consiguiente, para establecer que la comunidad pública viva como es debido, se requieren tres cosas: en primer lugar que los ciudadanos, una vez congregados, vivan en paz. En segundo lugar que los mismos ciudadanos, unidos por el vínculo de la paz, sean conducidos a obrar bien...

En tercer lugar se requiere que la comunidad pública goce, por arte y maña del gobierno, de las cosas que son necesarias para vivir bien" $(1, \mathrm{XV})$.

Pero, a pesar de estos ejemplos, los antecedentes próximos del estado social de derecho se hallan en el siglo XVIII -en la declaración francesa de los derechos del hombre de 1793, que ya consigna algunos derechos sociales- $y$, sobretodo, en el siglo XIX.

Abendroth reconoce la autoría de la fórmula a Owen y a Louis Blanc, siendo su contexto la Revolución de París de 1848 . El estado social "apareció por primera vez en la Revolución de París de 1848 , en aquel compromiso concertado entre los pequeños partidos demoliberales y las primeras asociaciones del movimiento obrero francés de ese período. La fórmula del 'Estado de Derecho democrático y social', tal y como entonces apareció en las publicaciones de Louis Blanc, tenía un contenido concreto, Iba referida al derecho al trabajo que entonces fue configurado como un derecho fundamental. Esto se explica porque la Revolución de 1848 fue consecuencia de una grave crisis económica con un paro [o desempleo] masivo. A la vez apuntaba al mandato que confería al Estado democrático para que creara por sí centros de producción que fuesen administrados por los trabajadores empleados en ellos con fórmula cooperativa y en concurrencia con el capitalismo privado de la primera época. Este conjunto de ideas fue vinculado entonces por Louis Blanc a la fórmula del Estado de Derecho democrático y social tomándola -si no literalmente, sí en el contenido- de Owen, que la había acuñado en los años treinta en los momentos iniciales del movimiento obrerista inglés" ${ }^{84}$. Luego, prosigue Abendroth, esta fórmula tuvo más de un desaparecimiento y resurgimiento; asimismo, la Revolución Rusa habría influido en ella ${ }^{85}$.

Garrorena -siguiendo de cerca a García-Pelayo- coloca el origen de esta fórmula en Louis Blanc y en Lorenz von Stein. "Ciertamente, el adjetivo [social] comenzó a ser

\footnotetext{
${ }^{83}$ SANTO TOMAS DE AQUINO, Sobre el Reino (trad. Antonino Tomás y Ballús, Poblet, Buenos Aires 1947).

84 ABENDROTH, WOLFGANG, "El Estado de Derecho democrático y social", en El Estado social (Centro de Estudios Constitucionales, Madrid 1986), pp. 15-16.

${ }^{85}$ ABENDROTH, WOLFGANG (n. 84), pp. 16-17.
} 
utilizado, con una significación avanzada y tratando ya de establecer una cierta correlación entre la acción social y la actividad del Estado, en los esquemas de determinados sectores socialistas operantes hacia la mitad del siglo XIX" ${ }^{86}$. Así ocurrió con Blanc en la década de 1840 -que, en buena medida, tradujo una conciencia difusa pero generalizada, prueba de lo cual es la revolución de 1848- y años después con Ferdinand Lasalle -en el interior del movimiento obrero alemán-; para ambos, el estado es el instrumento por excelencia para impulsar la transformación de la sociedad. En adelante, el adjetivo 'social' se consolidó en la izquierda: aparecieron los partidos 'social-demócratas' y 'socialistas' en Alemania (en 1869 y 1875), Dinamarca (en 1878), España (en 1879), Italia (en 1892), etc. Esta tendencia culminó en este siglo con Hermann Heller -como se verá más adelante- ${ }^{87}$. "Sin embargo, esta orientación de algunos sectores de la izquierda, partidarios de referir una cierta función social al Estado, se produce... a contrapelo de ese 'antiestatismo' que secularmente se considera que constituye un rasgo común a toda la tradición socialista...: es claro que, desde Saint-Simon a Lenin y desde Godwin a Bakunin, la revolución social no ha sido pensada a partir del Estado, sino frente al Estado, esto es, incluyendo entre sus metas el ideal de la extinción o disolución social del Estado mismo" ${ }^{88}$. Coexisten, pues, en la izquierda dos tradiciones: la 'socialdemócrata estatista' y la 'marxista antiestatista', con aproximaciones totalmente diversas a la cuestión del estado ${ }^{89}$.

Por otra parte, continúa Garrorena, desde posturas políticas conservadoras también se ha tendido a la apropiación del estado social. "Ya en 1850 Lorenz von Stein utilizó el adjetivo 'social' referido a la Monarquía germánica del XIX, en un intento de compaginar -tal era su 'Monarquía social'- el progreso de las clases menos privilegiadas con la conservación de las instituciones más tradicionales" ${ }^{90}$. En similar sentido se utilizó esta fórmula por Rösler, por las políticas de Napoleón III y Bismarck, y en España desde mediados del $X I X^{91}$. Pero esta apropiación conservadora del estado social se hizo evidente a fines de la primera guerra mundial y, sobretodo, con la gran depresión de 1929, si bien de dos maneras: de un lado, el fascismo y el nazismo asumieron este calificativo, y de otro, el capitalismo democrático lo reclamó para sí (como quedó de manifiesto en las ideas de Keynes, el plan Beveridge en Inglaterra, el plan Monnet en Francia y la economía social de mercado alemana $)^{92}$.

Dentro ya de este siglo, el estado social es la respuesta a las exigencias de un determinado ambiente social, que fue el que resquebrajó al estado liberal. Dicho ambiente presenta los siguientes rasgos: una declinación de la legitimidad de la dominación burguesa, una emergencia del proletariado y de la clase media, un aumento del poder sindical y de la influencia política de los movimientos marxistas -sea a través de la toma del poder político estatal, sea mediante la presión sobre dicho poder-y, también, un conjunto de mutaciones económicas y tecnológicas. Así, se diseñan políticas económi-

86

GARRORENA, ANGEL (n. 69), p. 30.

87 GARRORENA, ANGEL (n. 69), pp 30-34.

88 GARRORENA, ANGEL (n. 69), pp. 34-35.

${ }^{89}$ GARRORENA, ANGEL (n. 69), p. 36.

90 GARRORENA, ANGEL (n. 69), p. 37.

91 GARRORENA, ANGEL (n. 69), pp. 37-38.

92 GARRORENA, ANGEL (n. 69), pp. 39-40. 
cas y sociales para hacer frente a este ambiente social. En lo económico, aparecieron las ideas de Keynes -como lo señalaba Garrorena-: 'el' objetivo de la política económica es el pleno empleo; para ello debe elevarse la demanda y el consumo, con el fin de estimular la producción; la política salarial debe ser realista, aunque ha de permitir un cierto nivel adecuado de consumo; la inversión y el gasto público deben expandirse -junto con la inversión privada-, para así prever o paliar los eventuales efectos del ciclo económico; y, por fin, la coordinación, verificación y evaluación general de toda esta política debe quedar en manos del estado, el que expedirá las planificaciones indicativas o imperativas que pidan las circunstancias. En lo social, se realiza una política social global, sistemática y beneficiosa para la mayor parte de la población ${ }^{93}$. Asimismo, emergen los derechos sociales y se conceptúan los derechos individuales de manera que incluyan límites y funciones sociales ${ }^{94}$. Además, la administración pública deviene, según Forsthoff, administración abastecedora -'leistende Verwaltung'- con una constitutiva preocupación por la asistencia vital -'Daseinsvorsorge'-. ¿Cómo es esto? Desde el pasado siglo que el hombre ha enfrentado la satisfacción de sus necesidades vitales en enorme dependencia de las prestaciones que el estado le franquea; el hombre, pues, encuentra que el suyo es un espacio vital que no domina, y no un espacio vital del cual sea señor, como antes, es decir, el ámbito de la vida del hombre depende hoy -en mucha mayor medida que antes- del poder público. De ahí que a los fines tradicionales encomendados a la administración -como el bien común, la prosperidad, el servicio público, los intereses generales, etc.-, se añade el de la Daseinsvorsorge. Incluso puede decirse que la Daseinsvorsorge es lo que caracteriza a la administración contemporánea ${ }^{95}$. Este cambio de la administración pública es una de las caras del innegable aumento de los cometidos estatales, que ha provocado los siguientes efectos: “ ... el aumento progresivo en 'cantidad y complejidad' de la 'actividad estatal'; el crecimiento de la 'burocracia' en cantidad y en poderío; la necesidad cada vez mayor de la 'técnica'; la creciente pretensión de 'participación' de los 'grupos de interés'; la 'decadencia de la ley' y de los órganos encargados de dictarla" 196 . En particular, hay una declinación tanto de la generali-

93

BELMAR, FRANCISCO, El Estado social de Derecho en el constitucionalismo nacional y comparado (Memoria de Prueba, Universidad Católica de Chile 1986), pp. 204-206. Ver VANOSSI, JORGE REINALDO (n. 75), pp. $282-283$.

94

BELMAR. FRANCISCO (n. 93), p. 207. Sobre esto, ver MAYORGA, ROBERTO, "Los derechos económicos, sociales y culturales. Naturaleza jurídica", en Cuadernos de análisis jurídico 6 (1988); y NOVOA MONREAL, EDUARDO, El derecho de 95 propiedad privada. Concepto, evolución y crítica (Cepla 1989).

5 MARTIN-RETORTILLO, LORENZO, "La configuración juridica de la Administración pública y el concepto de 'Daseinsvorsorge"', en Revista de Administración Pública 38 (1962), pp. 39-47 y 64. Ver CORTIÑAS-PELAEZ, LEON, "Teoría general de los cometidos del poder público", en Revista de Administración Pública 111 (1986). pp. 62-87: GARRIDO FALLA. FERNANDO, Tratado de Derecho Administrativo (Instituto de Estudios Políticos, Madrid 1974) 2, pp. 140-141; GARCIA DE ENTERRIA, EDUARDO y FERNANDEZ, TOMAS-RAMON, Curso de Derecho Administrativo (Civitas, Madrid 1988) 2, pp. 5658 y 66-67; y CALDERA, HUGO, Manual de Derecho Administrativo (Jurídica de Chile, Santiago de Chile 1979). pp. 39-40. Oelckers señala que, en el estado contemporáneo, la administración tiene las siguientes características: es interventora de la vida económica y social (subsidiariamente en la ejecución, mas no en la orientación, estímulo y coordinación), a través de una acción planificadora (de modo indicativo) sujeta a control; la administración es, como el estado, plenamente responsable (sea por el hecho propio o por hechos imputables a sus agentes); desarrolla una política social gracias al presupuesto estatal, pero también a través de las empresas públicas, las inversiones prioritarias según los programas del plan indicativo, el crédito público y la regulación del comercio y de la banca; el administrado influye directamente en las decisiones que le afectan. Todo esto provoca ciertos cambios en el derecho administrativo. Ver OELCKERS, OSVALDO, "Los nuevos roles de la Administración Pública contemporánea y su regulación por el Derecho Administrativo", en Revista de Derecho. Universidad Católica de Valparaiso 8 (1984), pp. 188-195.

96 JUSTO LOPEZ, MARIO (n. 13), p. 291. Ver DIAZ, ELIAS (n. 36), p. $87-88$. 
dad, impersonalidad y permanencia de la ley, como de la legislación misma y de los órganos legisladores". "En lugar de pocas leyes, generales, impersonales, permanentes, se ha producido el fenómeno de su proliferación, la pérdida de su generalidad y la continua modificación o derogación de las normas. A ello se agrega que el órgano (u órganos) tradicionalmente encargado de la función de legislar, ha sido suplantado, cada vez más, por la acción invasora de los órganos encargados del poder ejecutivo, de la burocracia, de los técnicos y de los grupos de presión. Una manifestación muy ostensible del fenómeno ha sido la llamada 'delegación' de la 'competencia' o de las 'facultades legislativas"' ${ }^{98}$.

Asumiendo estos hechos e ideas, Hermann Heller precisó la noción del estado social de derecho en su '¿Estado de Derecho o dictadura?' de 1929. Allí "... sostiene la tesis de que sólo la transformación del Estado de Derecho en un Estado social de Derecho podría evitar la caída en un régimen dictatorial... La diferencia entre el Estado de Derecho y el Estado social de Derecho radicaría, según Heller, en que el primero atiende sólo a la vertiente formal del principio de igualdad (lo importante es que, para el Derecho, todos tengan iguales derechos, con independencia de que no estén realmente en situación de disfrutarlos y ejercitarlos por igual) y prescinde de las relaciones sociales de poder (incurriendo en el riesgo de que la igualdad formal de todos se convierta en el derecho de los más poderosos de hacer valer sin contemplaciones su superioridad real), mientras que para el segundo lo decisivo ha de ser la igualdad en sentido material (por lo que tiene la obligación, atendiendo a las relaciones sociales de poder, de corregir las desigualdades, garantizando que los débiles socialmente cuenten efectivamente con una libertad y una protección judicial equivalentes a las de los socialmente favorecidos) 1199 .

Pese a la filiación socialista de Heller, y a la indudable contribución socialista durante el siglo pasado, el estado social de derecho es una forma jurídica y política que ha asumido el capitalismo democrático en este siglo. Esta es, justamente, la tesis de Elías Díaz: el estado social de derecho, que conserva los rasgos básicos del estado liberal de derecho, es una revisión del individualismo y del abstencionismo estatal propios de éste, y se caracteriza por el intervencionismo estatal y por la fortaleza y el control del ejecutivo ${ }^{100}$. En el estado social de derecho "el calificativo social quiere ahí hacer referencia... a la corrección del individualismo clásico liberal a través de una afirmación de los llamados derechos sociales y de una realización de objetivos de justicia social" ${ }^{101}$. Con el estado social "... lo que se viene a poner ahora en tela de juicio es la eficacia del liberalismo clásico como sistema capaz de resolver los difíciles y complejos problemas que en el marco de una moderna sociedad industrial se plantean tanto con respecto de la expansión y el desarrollo económico como de la acción ejecutiva y administrativa de

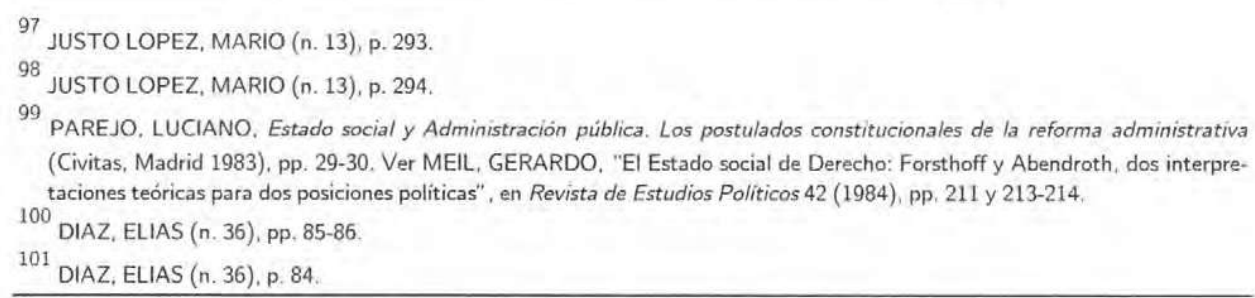


los órganos de gobierno"102 "Lo característico del Estado social de Derecho es, sin duda alguna, el propósito de compatibilizar en un mismo sistema dos elementos: uno, el capitalismo como forma de producción, y otro, la consecución de un bienestar general. La creencia en la posibilidad de semejante compatibilidad constituye precisamente el elemento psicológico, y al mismo tiempo ideológico, que sirve de base al neocapitalismo típico del 'Welfare State"' 103 . En suma; el estado social de derecho es la institucionalización jurídico-política del 'Welfare State'104.

Pero, ¿cuáles son los rasgos del estado social de derecho? El problema es que el estado social no es algo ya constituido, como el estado de derecho. Es, más bien, un tipo estatal en proceso de constitución, por lo que es casi imposible señalar los elementos que imprescindiblemente lo constituyen. Por eso se expondrán los posibles sentidos de esta noción recurriendo a algunos autores -sobretodo españoles- que han intentado perfilarla.

Pérez Luño dice que el estado social de derecho atribuye "... a los poderes públicos la consecución de la 'procura existencial' ('Daseinsvorsorge'); es decir, responsabiliza a la Administración de la tarea de proporcionar a la generalidad de los ciudadanos las prestaciones necesarias y los servicios públicos adecuados para el pleno desarrollo de su personalidad reconocida no sólo a través de las libertades tradicionales, sino también a partir de la consagración constitucional de los derechos fundamentales de carácter económico, social y cultural. Al propio tiempo, el Estado social de Derecho pretende asumir el cometido de reestructurar y equilibrar las rentas mediante el ejercicio de la política fiscal..." ${ }^{105}$. Agrega que entre los autores (sobretodo alemanes) hay dos posturas acerca del estado social de derecho. Una es la de Carl Schmitt, que vació de contenído a su dimensión social (a partir de la constitución de Weimar). Su discípulo Ernst Forsthoff -como se verá más adelante- continuó con su reflexión. La otra postura afirma que el paso del estado liberal al social comporta un cambio de significación jurídicopolítica. El estado social de derecho supone la garantía material de los postulados y libertades formales del estado liberal, lo que acarrea cambios en sus técnicas operativas. Se trata de conciliar las libertades individuales con la justicia social. En concreto, las notas distintivas del estado social de derecho (democrático) serían:

- la continuidad entre los principios social y democrático y el estado de derecho;

- el término de la separación estado-sociedad y, con ello, la responsabilidad estatal en la transformación del orden económico-social;

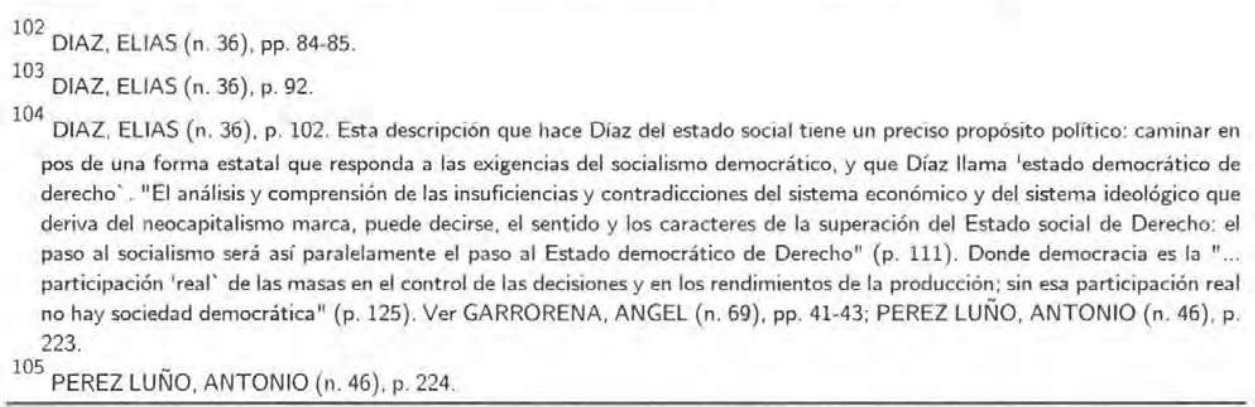


- los derechos fundamentales, que dejan de ser meros límites (negativos) de la actuación estatal; más bien, son instrumentos jurídicos de control de su actividad positiva. Por tanto, deben incluirse los derechos económicos, sociales y culturales, premunidos de acción;

- la pluralidad de la estructura estatal, de modo que permita la participación política, económica y cultural de las personas y de los grupos; y

- la conservación de las técnicas propias del estado de derecho ${ }^{106}$.

Parejo, siguiendo a Schiller, afirma que el estado social implica la superación del estado liberal, puesto que asegura "... la responsabilidad del Estado (en tanto que parte misma de la sociedad) en orden a las condiciones sociales, de modo que a los fines del mismo se incorporan las necesidades y las metas sociales, correspondiéndole la satisfacción de necesidades comprobadas y la consecución de objetivos prefijados; en definitiva, el logro y el mantenimiento de determinadas conquistas sociales y niveles de calidad de vida (en todos los órdenes) en común"107 . Y junto a esa responsabilidad, el estado social se caracteriza por su fin, que son unos determinados resultados sociales. En suma, el estado social es "... el por ahora último estadio de una sociedad secularizada, que ha sustituido su cohesión en razón a un orden de valores religioso o ético-moral por un orden de principios objetivos constitucionales [Parejo piensa en el estado social alemánl, único capaz de expresar la vinculación social a un proyecto de vida en común"108'

Avanzando un poco más, Vanossi trata el estado social de derecho dentro de lo que él denomina democracia social, ya que el modelo político de la democracia social se corresponde con el modelo constitucional del estado social de derecho ${ }^{109}$. ¿Qué es la democracia social? Es una profundización de la democracia política; por eso no abandona los principios de esta última ni los del constitucionalismo clásico. Descansa tanto en la libertad como en la igualdad; es, si cabe decirlo así, la confluencia de la socialdemocracia, la enseñanza social de la Iglesia y algunas vertientes neoliberales. Se distingue por dos rasgos: uno, "... la aparición de los 'derechos sociales' como una ampliación de los derechos subjetivos 'individuales' que había consagrado el constitucionalismo clásico..."; dos, "... el tránsito del Estado 'pasivo' o abstencionista a un Estado 'activo' e intervencionista o provisor..." ${ }^{110}$. En lo político, la democracia social respeta los postulados del constitucionalismo; en lo económico, pretende la justicia distributiva con respeto de la producción, pues antes que colectivizar los bienes de producción, pone el acento en la asunción de los riesgos primordiales por parte de la comunidad. Entonces, lo que la democracia social busca es la igualdad de oportunidades, como una manera de actualizar la igualdad meramente formal y de beneficiar a la mayor parte de la población ${ }^{111}$. Y, como se dijo, los derechos sociales caracterizan a la democracia social, ya que implican nuevos legitimados y nuevas pretensiones subjetivas

\footnotetext{
${ }^{106}$ PEREZ LUÑO, ANTONIO (n. 46), pp. 224-229.

107 PAREJO, LUCIANO (n. 99), p. 34.

108 PAREJO, LUCIANO (n. 99), p. 34

${ }^{109}$ VANOSSI, JORGE REINALDO (n. 75), p. 17.

${ }^{110}$ VANOSSI, JORGE REINALDO (n. 75), pp. 16-18.

111 VANOSSI, JORGE REINALDO (n. 75), pp. 18-19.
} 
(amparadas dentro del estado y no frente a él). Estos derechos no se resuelven con abstenciones del estado, sino con prestaciones estatales; y por otro lado, son derechos de grupos o sectores ( $y$ no derechos universales, como lo son los individuales): por ejemplo, derechos de trabajadores, de la familia, del niño, etc. ${ }^{112}$. El problema de estos derechos radica en su operatividad. "En una paráfrasis de la clasificación ontológica de Constituciones que nos legara Karl Loewenstein [entre normativas, nominales y semánticas]..., nos atreveríamos a decir que las cláusulas económicas y sociales forman con demasiada frecuencia la parte 'nominal' de muchas Constituciones; y que, en algunos casos extremos, se advierte claramente el ridículo de ser la parte más 'semántica' de la Constitución" 113 .

Belmar asevera que el estado social "... es el que tiene como prius esencial el bienestar económico, social, ambiental y cultural de sus habitantes, satisfaciendo en plenitud la procura existencial de los mismos"114. Es un estado distribuidor, que se ocupa de la dirección del ciclo económico (con el fin de evitar sus desequilibrios) y de permitir la participación de la población en la toma de decisiones económicas; en este sentido, busca la expansión tanto del acceso de la población a la propiedad como del acceso al control de la gestión empresarial ${ }^{115}$. En cuanto a los derechos fundamentales, presentan en un estado social las siguientes líneas básicas (siguiendo a Combellas):

- los derechos fundamentales constituyen un sistema cuya fuerza proviene del orden de valores que consagra la constitución;

- dicho orden de valores está presidido por el valor de la dignidad humana; rre al revés;

- si antes los derechos fundamentales sólo valían en el ámbito de la ley, hoy ocu-

- la fuerza vinculante de estos derechos deriva directamente de la constitución (y no de la ley, que es un instrumento de realización de estos derechos);

- por ello, los derechos fundamentales vinculan tanto al administrador como al legislador;

- estos derechos son de dos clases, de libertad y económico-sociales; y

- los derechos no son sólo garantías de defensa frente al estado, sino también garantías de participación ${ }^{116}$.

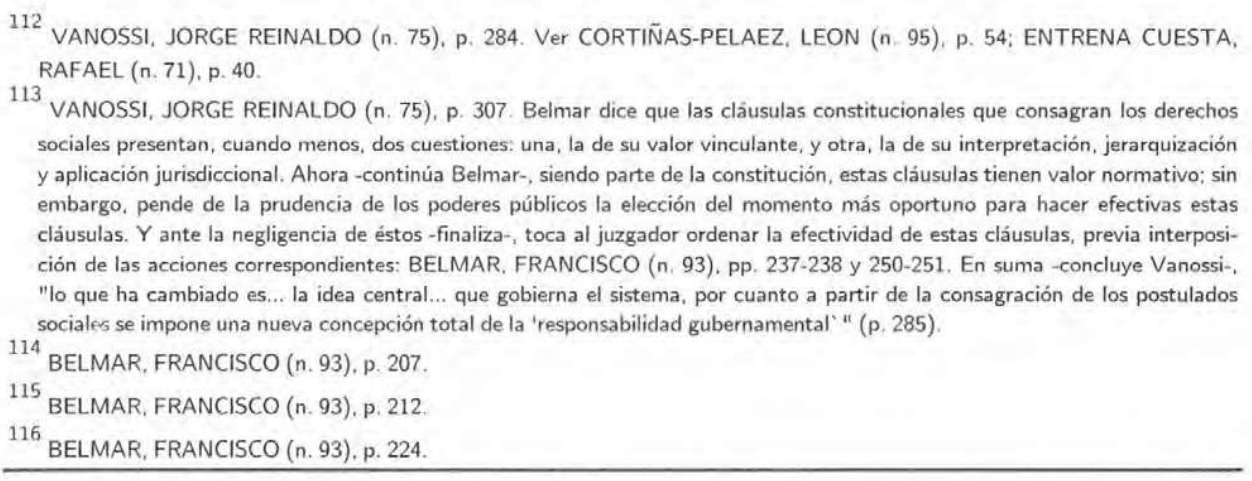


Por lo que se refiere a la separación de poderes, el estado social también le significa mutaciones (como afirma Combellas):

- hay una crisis del parlamento, que se manifiesta en:

* el incremento de la delegación legislativa,

* la declinación del parlamento como tribuna exclusiva de discusión y resolución de los asuntos públicos, y

* la incapacidad creciente del parlamento para afrontar el elevado tecnicismo que implican las decisiones estatales;

- el ejecutivo y -sobretodo- la administración se vigorizan, aumentando sus poderes discrecionales;

- el poder judicial también se vigoriza, sobretodo en cuanto al control de constitucionalidad de la acción del legislador y al control de legalidad de la actuación del administrador; además, el juez debe proteger el orden de valores que constituye al estado social, por cuanto dicho orden vincula a los poderes estatales; y

- la ley pasa a ser un medio para la consecución del bienestar social. Incluso llegan a haber tipos legales característicos:

* la ley medida: no crea un orden dentro del que se desarrolla la acción, sino que es un medio de acción; es temporal en cuanto a su validez, ya que se dicta en función de grupos o situaciones concretas; se define en función de la relación específica entre los medios y la finalidad a alcanzar, por lo cual su lógica depende de la concordancia entre medios y finalidad; y es una ley subordinada, ya que su fuerza depende de la finalidad a alcanzar,

* la ley programa: establece sólo las reglas básicas de la acción estatal,

* la ley de orientación: establece objetivos amplios, dada la magnitud del área donde pretende operar la ley, y

* la ley cuadro: establece principios generales de acción estatal, dejando amplio margen al gobierno y a la administración ${ }^{117}$.

Lucas Verdú asegura que el estado social de derecho "... es una feliz expresión que designa una realidad ya mentada anteriormente cuando la incorporación de los derechos sociales a las Constituciones europeas. Trátase del intento loable de convertir en derecho positivo viejas aspiraciones sociales, elevadas a la categoría de principios constitucionales protegidos por las garantías del Estado de Derecho. Son postulados, insertos en Constituciones rígidas, que obligan como derecho inmediatamente vigente, a la legislación, administración y justicia... y que están salvaguardados por Tribunales constitucionales.

Los derechos sociales ven reforzado su valor mediante garantías jurídicas claras y seguras. La seguridad social armoniza con la seguridad jurídica" ${ }^{118}$. El estado social de derecho es un producto de la fractura entre el estado de derecho y las demandas

\footnotetext{
117 BELMAR, FRANCISCO (n. 93), pp. 224-229.

118 LUCAS VERDU, PABLO (n. 32), pp. 84-85.
} 
sociales. "Pero el Estado de Derecho, que ya no podía justificarse como liberal, necesitó para afrontar la marea social arrojar por la borda su neutralidad, integrar en su seno a la sociedad sin renunciar al primado del derecho. El Estado de Derecho, en la actualidad, dejó de ser formal, neutral e individualista, para transformarse en Estado material de derecho, en cuanto adopta una dogmática y pretende la justicia social" ${ }^{119}$. Concretamente, ¿cuáles serían las funciones del estado social de derecho? Primero, la presión fiscal sobre las clases económicamente poderosas, cuyo objeto es la redistribución de la riqueza entre los económicamente débiles. Esto supone que es posible crear bienestar social a través de dicha política fiscal. En segundo término, las limitaciones e intervenciones en la propiedad privada, bien como socializaciones, bien como expropiaciones, etc. En tercer lugar, la intervención estatal en la economía nacional mediante la planificación, que ha sido definida como 'la elección consciente y deliberada de prioridades económicas por alguna autoridad pública'. Cuarto, el término de la necesidad por medio de planes de seguridad social. $Y$ en quinto término, la prospección o previsión de unas ciertas metas económicas y sociales que se desean alcanzar, sin las cuales es imposible cualquiera planificación. Esto último conlleva una determinada política financiera, de la que es evidente reflejo el gasto público ${ }^{120}$.

Finalmente, se consignan con alguna morosidad las ideas de García Pelayo, las que constituyen una de las mejores caracterizaciones del estado social. Dice este autor que el estado social (también llamado welfare state, estado socialdemócrata, estado de partidos o estado de asociaciones) "... significa históricamente el intento de adaptación del Estado tradicional (por el que entendemos en este caso el Estado liberal burgués) a las condiciones sociales de la civilización industrial y postindustrial con sus nuevos y complejos problemas, pero también con sus grandes posibilidades técnicas, económicas y organizativas para enfrentarlos. No hemos de ver las medidas de tal adaptación como algo totalmente nuevo, sino más bien como un cambio cualitativo de tendencias surgidas en el siglo XIX y comienzos del XX para regular, en aquel entonces, aspectos parciales de la sociedad, regulación que sufre en nuestro tiempo un proceso de generalización, integración y sistematización.

En efecto, desde el último tercio del siglo XIX se desarrolló en los países más adelantados una 'política social' cuyo objetivo inmediato era remediar las pésimas condiciones vitales de los estratos más desamparados y menesterosos de la población. Se trataba, así, de una política sectorial no tanto destinada a transformar la estructura social cuanto a remediar algunos de sus peores efectos y que no precedía, sino que seguía a los acontecimientos. En cambio, la actual política social de los países industrializados y postindustrializados extiende sus efectos no solamente a aspectos parciales de las condiciones de vida de las clases obreras, cuyo porcentaje sobre el total de la población tiende a disminuir, sino también a las clases medias, cuyo porcentaje ha aumentado considerablemente como consecuencia de la tecnificación del trabajo y del crecimiento del sector de servicios, e indirectamente sobre la totalidad de la población; tales medidas, además no se limitan a la menesterosidad económica, sino que se extienden también a otros aspectos como promoción del bienestar general, cultura, esparcimiento, educación, defensa del ambiente, promoción de regiones atrasadas, etc.

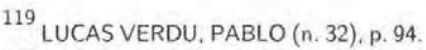

120 LUCAS VERDU, PABLO (n. 32), pp. 101-113. Este autor, además, estudia las características del estado social -o de bienestar-en Inglaterra, Estados Unidos, Francia, Italia, Suiza y Alemania (pp. 25-85).
} 
Resumiendo..., la política social sectorial se ha transformado en política social generalizada, la cual no constituye tanto una reacción ante los acontecimientos, cuanto una acción que pretende controlarlos mediante una programación integrada y sistemática.

Lo propio sucede en el campo económico. Si bien el Estado decimonónico debía obedecer al famoso principio del 'laissez faire', lo cierto es que en todos los países se establecieron medidas arancelarias destinadas a defender ramas económicas específicas de la competencia exterior, al menos -se decía- hasta que estuvieran en disposición de enfrentarla por sí solas; tampoco dejó de manifestar su presencia el subsidio estatal a esta o aquella actividad que convenía desarrollar por razones de interés nacional, ni de promoverse la educación tecnológica creando las correspondientes escuelas técnicas y, en general, de desplegarse una política de fomento destinada a actualizar directa o indirectamente (mediante la creación del adecuado ambiente) el potencial eonómico del país. Pero, en principio, se trataba de medidas subsidiarias correctivas de los malos efectos o de las deficiencias transitorias de un sistema considerado en general como autorregulado, del mismo modo que se corrige de tiempo en tiempo un reloj para que, en virtud de su mecanismo, siga marchando por la sola operación de éste. Ahora, en cambio, se tiende a una política estatal de dirección permanente y programada del conjunto, aunque no de los detalles, del sistema económico global y sin perjuicio del poder de decisión de las empresas privadas, dirección que no se limita a actuar bajo la coerción de una estructura dada del sistema económico..., sino que aquí el Estado puede promover el cambio, dentro de cietos límites, de la estructura misma del sistema económico frente y en el cual ha de operar.

Las condiciones históricas que han hecho posible el desarrollo de este nueva función del Estado que ni es socialista, ni es capitalista en el sentido clásico del concepto, sino que se corresponde con la etapa del neocapitalismo son, de un lado, un reto histórico, una necesidad de resolver problemas agobiantes irresolubles dentro de la estructura del Estado liberal y de la sociedad del 'Hochkapitalismus' y, de otro lado, las posibilidades ofrecidas por el desarrollo cultural y tecnológico de la época industrial" ${ }^{\prime 21}$.

"El Estado social... parte de la experiencia de que la sociedad dejada total o parcialmente a sus mecanismos autorreguladores conduce a la pura irracionalidad y que sólo la acción del Estado hecha posible por el desarrollo de las técnicas administrativas, económicas, de programación de decisiones, etc., puede neutralizar los efectos disfuncionales de un desarrollo económico y social no controlado. Por consiguiente, el Estado no puede limitarse a asegurar las condiciones ambientales de un supuesto orden social inmanente, ni a vigilar los disturbios de un mecanismo autorregulado, sino que, por el contrario, ha de ser el regulador decisivo del sistema social y ha de disponerse a la tarea de estructurar la sociedad a través de medidas directas o indirectas..."122. En esta estructuración social podrá seguirse la senda neocapitalista, o bien el camino del socialismo democrático ${ }^{123}$.

Entonces, "... es claro que si el Estado estructura y reestructura a la sociedad, que si su acción afecta a los intereses concretos de los grupos, estratos y en general de

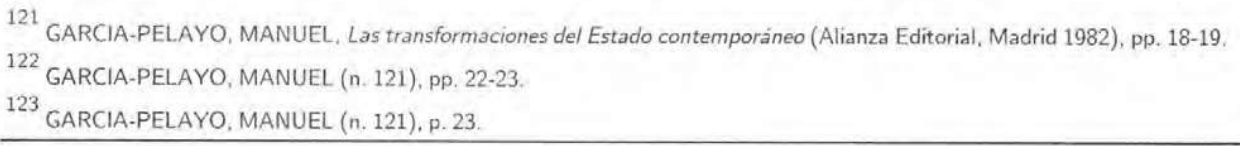


los actores sociales, a su vez éstos han de estar interesados... en influir la política del Estado y en interpenetrar sus centros de decisión y, de este modo, el Estado social está necesariamente vinculado con el influjo de los grandes grupos de intereses o de las grandes organizaciones destinadas a la defensa de intereses parciales o sectoriales en el sistema político" ${ }^{124}$. El estado social se encuentra, pues, con dos tendencias: "... con una tendencia a la estatización de la sociedad, pero también con una tendencia a la socialización del Estado y, por tanto, a la difuminación de límites entre ambos térmi$\operatorname{nos}^{125}$.

El estado social no es completamente diverso del liberal. "Los valores básicos del Estado democrático-liberal eran la libertad, la propiedad individual, la igualdad, la seguridad jurídica y la participación de los ciudadanos en la formación de la voluntad estatal a través del sufragio. El Estado social democrático y libre no sólo no niega estos valores, sino que pretende hacerlos más efectivos dándoles una base y un contenido material... Así, no hay posibilidad de actualizar la libertad si su establecimiento y garantías formales no van acompañadas de unas condiciones existenciales mínimas que hagan posible su ejercicio real; mientras que en los siglos XVIII y XIX se pensaba que la libertad era una exigencia de la dignidad humana, ahora se piensa que la dignidad humana (materializada en supuestos socioeconómicos) es una condición para el ejercicio de la libertad. La propiedad individual tiene como límite los intereses de la comunidad ciudadana y los sectoriales de los que participan en hacerla productiva, es decir, de los obreros y empleados. La seguridad formal tiene que ir acompañada de la seguridad material frente a la necesidad económica permanente o contingente a través de instituciones como el salario mínimo, la seguridad de empleo, la de atención médica, etc. La seguridad jurídica y la igualdad ante la ley han de ser complementadas con la seguridad de unas condiciones vitales mínimas y con una corrección de las desigualdades económico-sociales. Y, en fin, la participación en la formación de la voluntad estatal debe ser perfeccionada con una participación en el producto nacional a través de un sistema de prestaciones sociales y con una participación en la democracia interna de las organizaciones y de las empresas a través de métodos como el control obrero, la cogestión o la autogestión.

De este modo, mientras que el Estado tradicional se sustentaba en la justicia conmutativa, el Estado social se sustenta en la justicia distributiva; mientras que el primero asignaba derechos sin mención de contenido, el segundo distribuye bienes jurídicos de contenido material; mientras que aquél era fundamentalmente un Estado legislador, éste es, fundamentalmente, un Estado gestor a cuyas condiciones han de someterse las modalidades de la legislación misma (predominio de los decretos leyes, leyes medidas, etc.); mientras que el uno se limitaba a asegurar la justicia legal formal, el otro se extiende a la justicia legal material. Mientras que el adversario de los valores burgueses clásicos era la expansión de la acción estatal, para limitar la cual se instituyeron los adecuados mecanismos -derechos individuales, principio de la legalidad, división de poderes, etc.-, en cambio, lo único que puede asegurar la vigencia de los valores sociales es la acción del Estado, para lo cual han de desarrollarse también los adecuados mecanismos institucionales. Allí se trataba de proteger a la sociedad del Estado,

124

GARCIA-PELAYO, MANUEL (n. 121), pp. 24-25.

${ }^{125}$ GARCIA-PELAYO, MANUEL (n. 121), p. 25 
aquí se trata de proteger a la sociedad por la acción del Estado. Allí se trataba de un Estado cuya idea se realiza por la inhibición, aquí se trata de un Estado que se realiza por su acción en forma de prestaciones sociales, dirección económica y distribución del producto nacional" ${ }^{126}$.

Si -como dice Forsthoff- el estado social se endereza a la consecución de la procura existencial de toda la población, entonces ha de contemplar:

- sistemas o control de sistemas indispensables para el desarrollo de la civilización contemporánea;

- seguridad vital de la sociedad, (incluso frente a cualquier tipo de necesidad económica, frente al menoscabo del ambiente natural, etc.);

- prestaciones sociales no sólo proclamadas, sino también garantizadas (aunque esto no siempre es indispensable, como lo prueba la Ley Fundamental de Bonn). Dentro de estas prestaciones, aparece el salario mínimo; el acceso universal a un puesto de trabajo (mediante una política de pleno empleo); la atención de los incapacitados para el trabajo temporal o permanentemente; la justa distribución del ingreso en cada coyuntura económica; el acceso a los bienes culturales y la mantención de servicios sociales (sobretodo sistemas de seguros) ${ }^{127}$.

Del estado social -continúa García-Pelayo-, pueden anotarse una serie de rasgos:

a) Caracteriza al estado social -con mayor o menor intensidad- su calidad de empresario, "... sea mediante la estatización de las empresas, sea participando con el capital privado en empresas mixtas, sea poseyéndolas exclusivamente, pero bajo forma jurídica privada" ${ }^{128}$.

b) "Pero por importante que aquí o allá pueda ser el volumen de empresas bajo una u otra forma de propiedad estatal, es lo cierto que el Estado social no se centra tanto en la titularidad formal de los medios de producción, cuanto en la distribución de lo producido" 129 .

"Así pues..., podemos considerar al Estado social como la forma histórica superior de la función distribuidora que siempre ha sido una de las características esenciales del Estado, pues ahora no se trata sólo de distribuir potestades o derechos formales, o premios y castigos, ni tampoco de crear el marco general de la distribución de los medios de producción, sino que se trata también de un Estado de prestaciones que asume la responsabilidad de la distribución y redistribución de bienes y servicios económi$\cos ^{\prime \prime} 130$.

c) Consecuencia de esto es que "... la sola asunción por parte del Estado de la responsabilidad de la distribución del producto social conlleva su responsabilidad por la dirección general del proceso económico, dentro del marco de una economía de merca-

\footnotetext{
126

127

GARCIA-PELAYO, MANUEL (n. 121), pp. 26-27.

27 GARCIA-PELAYO, MANUEL (n, 121), pp. 27-30.

${ }^{128}$ GARCIA-PELAYO, MANUEL (n. 121), p. 30.

129 GARCIA-PELAYO, MANUEL (n. 121), p. 31.

${ }^{130}$ GARCIA-PELAYO. MANUEL (n. 121), p. 35.
} 
do, que el mismo Estado contribuye a regular estructural y coyunturalmente" ${ }^{131}$. Entonces, "... el Estado no puede limitarse a crear las condiciones jurídicas ambientales de un mercado supuestamente autorregulado, como era el caso del Estado liberal, sino que ha de asumir una actitud activa patentizada en constantes medidas destinadas a la regulación del crecimiento y a la orientación del proceso económico nacional hacia ciertos objetivos; a proporcionarle apoyo logístico, en lo que se cuentan actividades tales como obras de infraestructura, promoción de la innovación tecnológica, formación de cuadros y de personal calificado, etc., y, en fin, a la creación de las condiciones estructurales como la modernización de ciertos sectores, configuración del mercado, integración de la economía nacional en organizaciones supranacionales, etc. Ahora bien, todas estas y otras medidas aunque tomadas por el Estado en uso de su autoridad pública, han de ser decididas y operacionalizadas teniendo en cuenta la coerción objetiva de la realidad económica como un sistema con sus propias exigencias funcionales y los intereses convergentes o divergentes de los actores de este sistema. Dicho en otros términos: el Estado es simultáneamente 'señor y servidor del proceso económico'"' 132 .

d) Si cada tipo estatal posee una específica legitimación, “... el Estado social... va asociado a un principio de legitimidad constituido por la 'performance', la funcionalidad o la eficacia de su gestión, principio que coexiste con otros principios de legitimidad y que en el sistema del Estado social debe subordinarse o, si se quiere, interactuar con la legitimidad democrática" ${ }^{133}$.

e) Enseguida, el sujeto del estado social no es tanto el ciudadano como la persona en situación (obrero, consumidor, usuario de servicio público, afectado por la contaminación, etc.) y las organizaciones de intereses ${ }^{134}$.

f) El estado social se distingue por "... su capacidad para producir la integración de la sociedad nacional, o sea, el proceso constantemente renovado de conversión de una pluralidad en una unidad sin perjuicio de la capacidad de autodeterminación de las partes. Traducido a términos más concretos quiere decir no tanto la supresión de la lucha de clases o, más bien, de la pluralidad de grupos clasistas de la sociedad actual, cuanto su reducción a conflictos parciales y resolubles por vías jurídicas o por acuerdo entre las partes, y su encapsulamiento dentro del ámbito de una empresa o de un sector industrial, sin que el conflicto llegue a adquirir extensión nacional y se transforme en un proceso de antagonización política radical" ${ }^{135}$.

g) El estado social, además, "... tiene como supuesto la democracia política, pero se caracteriza, además, por su tendencia hacia la instauración de la democracia social, cuyas formas capitales son la democracia económica y la democracia empresarial" "136. ¿A qué alude la democracia social? "... La democracia social no se refiere solamente a la intervención en los criterios de distribución del producto, sino también a la participación en las decisiones de las grandes líneas de las políticas económicas y al

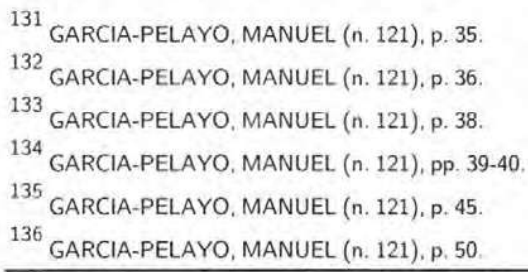


proceso de gestión y producción empresariales" ${ }^{137}$. La democracia social aumenta la eficacia del estado social: los problemas de las complejas sociedades contemporáneas han de abordarse compleja y pluralmente, y la democracia -basada en el pluralismo y la complejidad- es la mejor manera de hacerlo.

h) El estado social, como es claro, es un estado material de derecho y no uno formal, esto es, se caracteriza, más que por la forma de la acción del estado, por el contenido de la acción estatal (aunque de todos modos conserve los mecanismos del estado liberal) ${ }^{138}$. "El Estado social de Derecho acoge los valores jurídico-políticos clásicos; pero de acuerdo con el sentido que han ido tomando a través del curso histórico y con las demandas y condiciones de la sociedad del presente. Además, a tales derechos clásicos añade los derechos sociales y económicos y, en general, los derivados de la función de la procura existencial"139.

i) El estado social implica un cambio en el sentido que tiene la división de poderes. Clásicamente, dicha división se sustentaba en considerar como valor máximo y exclusivo a la libertad; en asignar cada función estatal a un órgano distinto; y en fundar cada poder en una realidad social autónoma. Contemporáneamente, la libertad aparece necesitando a la seguridad económica; cada poder estatal cumple hoy diversas funciones y cada función es asumida por diversos poderes; y se ha quebrado definitivamente la sustentación de cada poder en una realidad social autónoma. Además, la administración se transforma -cada vez más claramente- en un cuarto poder. Y como los partidos políticos y los grupos de interés relativizan la autonomía del gobierno y el parlamento, surge el control de constitucionalidad de la administración y de la legislación ${ }^{140}$.

j) ¿Y el principio de legalidad? "... Podemos llegar a la conclusión que Estado social de Derecho significa un Estado sujeto a la ley legítimamente establecida con arreglo al texto y a la praxis constitucionales con indiferencia de su carácter formal o material, abstracto o concreto, constitutivo o activo, y la cual, en todo caso, no puede colidir con los preceptos sociales establecidos por la Constitución o reconocidos por la praxis constitucional como normativización de unos valores por y para los cuales se constituye el Estado social y que, por tanto, fundamentan su legalidad"141.

k) Enseguida, es frecuente en el estado social la aparición de nuevos contralores de legalidad y constitucionalidad (así, el Ombudsman y órganos paraestatales o sociales de control) ${ }^{142}$. Dicho control, en tanto, ya no es solamente formal, "... sino que ha de incidir también en el examen de los valores materiales establecidos por la Constitución..." ${ }^{143}$.

1) Por fin: el estado social es la forma estatal que se corresponde históricamente con el neocapitalismo o capitalismo tardío. Este neocapitalismo se funda tanto en la

\footnotetext{
137 GARCIA-PELAYO, MANUEL (n, 121), p. 50.

${ }^{138}$ GARCIA-PELAYO, MANUEL (n. 121), p. 54.

139 GARCIA-PELAYO, MANUEL (n. 121), p. 56.

${ }^{140}$ GARCIA-PELAYO, MANUEL (n. 121), pp. 57-61.

${ }^{141}$ GARCIA-PELAYO, MANUEL (n. 121), p. 64.

${ }^{142}$ GARCIA-PELAYO, MANUEL (n. 121), pp, 65-66.

${ }^{143}$ GARCIA-PELAYO. MANUEL (n. 121), p. 65.
} 
innovación tecnológica como en la economía de mercado (y sus correcciones sociales), y sus objetivos son: el crecimiento del consumo y del bienestar social, el pleno empleo y un crecimiento constante. Sus actores principales son: el estado, las macroempresas y organizaciones de interés y los partidos políticos. Pero de todos modos, el estado social es compatible con el socialismo democrático ${ }^{144}$.

\subsection{Breve incursión en la doctrina cristiana}

A esta altura, es preciso detenerse -muy brevemente- en los hitos del pensamiento cristiano en su consideración de las consecuencias sociales de la dignidad humana y de las consiguientes responsabilidades sociales del poder público. Con esta detención-y sólo ése es su objeto-, se apreciará alguna semejanza entre los elementos del estado social de derecho y las ideas esenciales que tiene en esta materia el pensamiento cristiano. Para no ir más lejos de la cuenta, habrá que ceñirse a la enseñanza social de la Iglesia Católica contemporánea, sobretodo a las encíclicas papales ${ }^{145}$.

En Rerum novarum, León XIII dice que al estado le incumbe la protección del necesitado, si bien no debe pasar a llevar su libertad, "Exige, pues, la equidad que la autoridad pública tenga cuidado del proletario, haciendo que le toque algo de lo que aporta él a la común utilidad, que teniendo casa en que morar, vestido con que cubrirse y protección con que defenderse de quien atente a su bien, pueda soportar la vida con

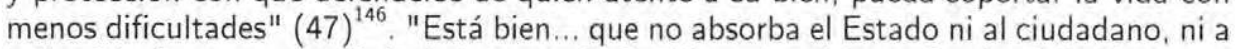
la familia; justo es que al ciudadano y a la familia se les deje en facultad de obrar con libertad en todo aquello que, salvo el bien común y sin perjuicio de nadie, se puede hacer... Deben, sin embargo, los que gobiernan proteger la comunidad y los individuos que la forman" (48). Esto es, ".. los que gobiernan un pueblo deben primero concurrir a la solución del problema de una forma general, con todo el complejo de leyes e instituciones, es decir, haciendo que de la misma ordenación y administración de la cosa pública espontáneamente brote la prosperidad, así de la comunidad como de los particulares" (44). La acción del estado, entonces, es necesaria pero restringida: el poder público ha de velar por el bien material y moral del obrero.

De un modo similar se expresó años después Pío XI. "Ciertamente, no debe faltar a las familias ni a los individuos una justa libertad de acción, pero con tal que quede a salvo el bien común y se evite cualquier injusticia. A los gobernantes toca defender a la comunidad y a todos sus miembros; pero, al proteger los derechos de los particulares, deben tener principal cuenta de los débiles y de los desamparados" $(18)^{147}$. El estado ha

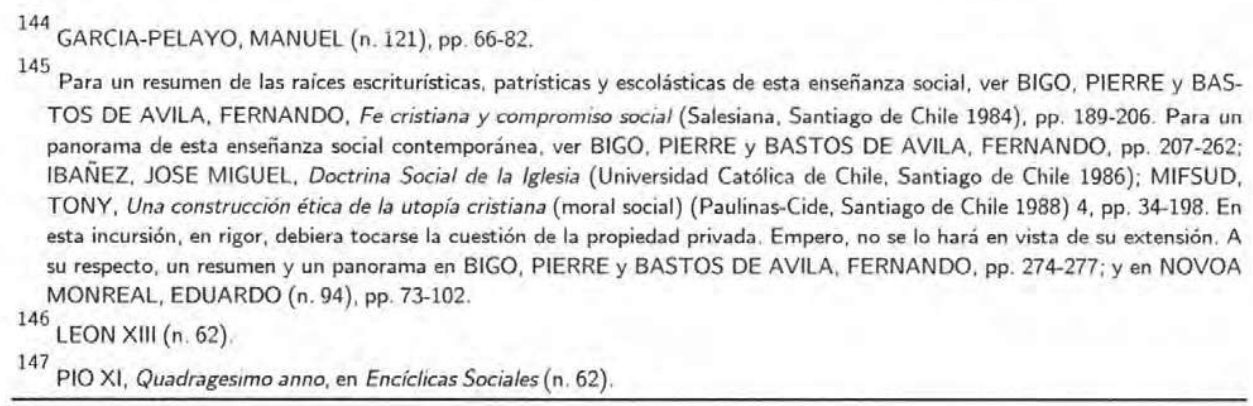


de actuar subsidiariamente, o sea, sólo a falta del grupo menor o inferior. Tal principio dice: "... es ilícito quitar a los particulares lo que con su propia iniciativa y propia industria pueden realizar, para entregarlo a una comunidad,... es injusto y al mismo tiempo de grave perjuicio y perturbación del recto orden social, confiar a una sola sociedad mayor y más elevada lo que pueden hacer y procurar comunidades menores e inferiores... Por tanto, tengan bien entendido esto los que gobiernan: cuanto más vigorosamente reine el orden jerárquico entre las diversas asociaciones, quedando en pie este principio de la función supletiva del Estado, tanto más firme será la autoridad y el poder social, y tanto más próspera y feliz la condición del Estado" (54).

Después, la Mater et Magistra de Juan XXIII suministró importantes reflexiones. Este papa percibió a la socialización como un signo de los tiempos, una de cuyas manifestaciones es la "... creciente intervención de los poderes públicos aun en los sectores más delicados, como los relativos a la sanidad, la instrucción y la educación de las nuevas generaciones, la orientación profesional, los métodos para la reeducación y readaptación de sujetos deficientes en una u otra manera..." $(60)^{148}$. Tal fenómeno acarrea peligros; pero también beneficios: "en efecto, hace que puedan satisfacerse muchos derechos de la persona, particularmente los llamados económico-sociales, como, por ejemplo, el derecho a los medios indispensables para el sustento humano, a la asistencia sanitaria, a una instrucción básica más elevada, a una formación profesional más completa, a la habitación, al trabajo, a un descanso conveniente, a la recreación" (61). Por otra parte, la riqueza nacional debe distribuirse: "... la riqueza económica de un pueblo no consiste solamente en la abundancia total de los bienes, sino también, y más aún, en la real y eficaz distribución según justicia para garantía del desarrollo personal de los miembros de la sociedad, en la que consiste el verdadero fin de la economía nacional" (74). Juan XXIII alude concretamente a las dificultades del sector agrario, a los servicios públicos esenciales (127), a los sectores productores (129-130) y a diversos instrumentos de política económica (131): los tributos (132-133), el crédito (134), la seguridad social (135-136), la defensa de los precios (137-140), la integración de los réditos agrícolas (141), la adecuación de las estructuras de la empresa agrícola (142143). Enseguida, se afirma que los poderes públicos deben eliminar o disminuir las desigualdades sociales (150), respetando sí el principio de subsidiariedad (152). Para ello, "... se debe procurar que en las zonas menos desarrolladas se aseguren los servicios públicos esenciales... Pero es también necesario que se emprenda una política económico-social apropiada, principalmente respecto de la oferta de trabajo y los traslados de la gente, los salarios, las contribuciones, el crédito, las inversiones..." (150).

En Pacem in terris, Juan XXIII asegura que el hombre tiene derecho a los elementos que le permiten llevar una vida digna: alimentación, vestido, habitación, descanso, atención médica, servicios sociales necesarios, seguridad -en caso de enfermedad, vejez, invalidez, viudez, desempleo u otra eventualidad similar-(11) ${ }^{149}$. El hombre tiene derecho a participar de los bienes de la cultura y a recibir educación (13). Tiene derecho al trabajo, a condiciones laborales humanas y a un salario justo (18-20). Por esto es por lo que los poderes públicos deben proteger y promover los derechos del hombre (60). "Es por eso indispensable que los poderes públicos pongan esmerado

\footnotetext{
148 JUAN XXIII, Mater et Magistra, en Enciclicas Sociales (n. 60).

149 JUAN XXIII (n, 60)
} 
empeño para que al desarrollo económico corresponda igual progreso social, y que en proporción de la eficiencia de los sistemas productivos se desarrollen los servicios esenciales... Y no menor empeño habrán de poner los que tienen el poder civil en lograr que a los obreros aptos para el trabajo se les ofrezca la oportunidad de conseguir empleos adecuados a sus fuerzas; que la remuneración del trabajo se determine según criterios de justicia y equidad,..." (64).

La Gaudium et Spes del Concilio Vaticano II advierte que, para que el proceso económico quede bajo el gobierno de los hombres, es preciso "... que la iniciativa espóntanea del individuo y de los grupos sociales libres se coordinen con los esfuerzos de las autoridades públicas en orgánica y concertada armonía" $(65)^{150}$.

Populorum Progressio, en tanto, afirma que "la sola iniciativa individual y el simple juego de la competencia no serían suficientes para asegurar el éxito del desarroIlo... Los programas son necesarios para 'animar, estimular, coordinar, suplir e integrar' la acción de los individuos y de los cuerpos intermedios. Toca a los poderes públicos escoger y ver el modo de imponer los objetivos que hay que proponerse, las metas que hay que fijar, los medios para llegar a ellas, estimulando al mismo tiempo todas las fuerzas agrupadas en esta acción común" $(33)^{151}$. Todo programa existe "... para re-

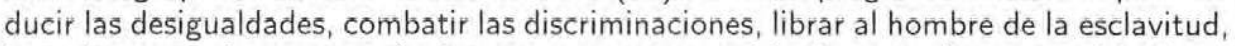
hacerlo capaz de ser por sí mismo agente responsable de su mejora material, de su progreso moral y de su desarrollo espiritual" (34).

En el campo del trabajo, Laborem Exercens dice que "... es el Estado el que debe realizar una política laboral justa" $(17)^{152}$. Tal política laboral repercute en el empleo (18) y en el salario y otras prestaciones sociales (19).

Libertatis conscientia, sistematizando buena parte de esta enseñanza social, reafirma conjuntamente los principios de subsidiariedad y solidaridad, de los cuales el primero señala que "... ni el Estado ni sociedad alguna deberán jamás substituir la iniciativa y la responsabilidad de las personas y de los grupos sociales intermedios en los niveles en los que éstos pueden actuar, ni destruir el espacio necesario para su libertad", mientras que el principio de solidaridad implica que "... el hombre debe contribuir con sus semejantes al bien común de la sociedad, a todos los niveles" $(73)^{153}$.

Centesimus Annus, la última de las Ilamadas encíclicas sociales, celebra -al releer Rerum Novarum- "... 'la constante preocupación y dedicación de la Iglesia' por aquellas personas que son objeto de predilección por parte de Jesús... El contenido del texto es un testimonio excelente de la continuidad, dentro de la Iglesia, de lo que ahora se llama 'opción preferencial por los pobres'...

Si León XIII se apela al Estado para poner un remedio justo a la condición de los pobres, lo hace también porque reconoce oportunamente que el Estado tiene la incumbencia de velar por el bien común y cuidar que todas las esferas de la vida social, sin

\footnotetext{
${ }^{150}$ CONCILIO VATICANO II (n. 62).

${ }^{151}$ PABLC VI, Populorum Progressio, en Enciclicas Sociales (n. 60).

152 JUAN PABLO II, Laborem Exercens (Paulinas, Santiago de Chile 1983).

153 CONGREGACION PARA LA DOCTRINA DE LA FE, Instrucción sobre libertad cristiana y liberación (Paulinas, Santiago de Chile 1986).
} 
excluir la económica, contribuyan a promoverlo, naturalmente dentro del respeto debido a la justa autonomía de cada una de ellas" $(11)^{154}$. Para defender al trabajador frente a la amenaza del desempleo, asegurar salarios justos y garantizar horarios humanos de trabajo, "... el Estado debe participar directa o indirectamente. Indirectamente y según el 'principio de subsidiaridad', creando las condiciones favorables al libre ejercicio de la actividad económica, encauzada hacia una oferta abundante de oportunidades de trabajo y de fuentes de riqueza. Directamente y según el 'principio de solidaridad', poniendo, en defensa de los más débiles, algunos límites a la autonomía de las partes que deciden las condiciones de trabajo, y asegurando en todo caso un mínimo vital al trabajador en paro" (15). Así, una sociedad respetuosa de la dignidad del hombre, no "... se opone al mercado, sino que exige que éste sea controlado oportunamente por las fuerzas sociales y por el Estado, de manera que se garantice la satisfacción de las exigencias fundamentales de toda la sociedad" (35), puesto que "es deber del Estado proveer a la defensa y tutela de los bienes colectivos, como son el ambiente natural y el ambiente humano, cuya salvaguardia no puede estar asegurada por los simples mecanismos de mercado" $(40)^{155}$.

¿Cuáles son, en suma, los hitos fundamentales hallados en este recorrido?:

a) El poder público tiene una precisa responsabilidad social, que es la de asumir las consecuencias sociales que emanan de la dignidad humana a través de la promoción de la justicia en los diversos ámbitos de la sociedad -sin menoscabo, por cierto, de la libertad humana bien entendida-;

b) En cumplimiento de dicha responsabilidad, el poder público ha de actuar subsidiariamente; si un grupo inferior es capaz de afrontar adecuadamente la tarea de la promoción de la justicia, el poder público no debe sustituirlo, y viceversa; y

c) A esta responsabilidad corresponden unos derechos derivados de la dignidad de la persona humana de ver satisfechas las necesidades humanas fundamentales.

Resta, por último, explicitar la raíz teológica de esta enseñanza social. Y ésta es, sin duda posible, la sacralidad de la persona humana y, en particular, el amor predilecto y justiciero del Dios cristiano por los pobres. Sobre esto, el Documento de Puebla hace una adecuada síntesis. "El compromiso evangélico de la Iglesia... debe ser como el de Cristo: un compromiso con los más necesitados (Cfr. Lc. 4, 18-21... ). La Iglesia debe mirar, por consiguiente, a Cristo cuando se pregunta cuál ha de ser su acción evangelizadora. El Hijo de Dios demostró la grandeza de ese compromiso al hacerse hombre, pues se identificó con los hombres haciéndose uno de ellos, solidario con ellos y asumiendo la situación en que se encuentran, en su nacimiento, en su vida y, sobre todo, en su Pasión y muerte donde llegó a la máxima expresión de la pobreza (Cfr. Flp. 2, 511...).

Por esta sola razón, los pobres merecen una atención preferencial, cualquiera que sea la situación moral o personal en que se encuentren. Hechos a imagen y semejanza de Dios (Cfr. Gén. 1, 26-28) para ser sus hijos, esta imagen está ensombrecida y

\footnotetext{
154 JUAN PABLO I $(\mathrm{n}, 61)$,

${ }^{155}$ Ver, además, los números 48,49 y 52.
} 
aún escarnecida. Por eso Dios toma su defensa y los ama (Cfr... Sant. 2, 5)" (1141$1142)^{156}$.

Incluso es probable que las bienaventuranzas evangélicas hayan nacido de las siguientes palabras de Jesús:

\author{
"Bienaventurados los pobres, \\ porque Dios reinará en su favor. \\ Bienaventurados los sufridos, \\ porque Dios los consolará. \\ Bienaventurados los hambrientos, \\ porque Dios los saciará" 157
}

De ahí el horizonte dibujado por Pablo VI en Populorum Progressio: "se trata de construir un mundo donde todo hombre, sin excepción de raza, religión o nacionalidad, pueda vivir una vida plenamente humana, emancipado de las servidumbres que le vienen de parte de los hombres y de una naturaleza insuficientemente dominada; un mundo donde la libertad no sea una palabra vana y donde el pobre Lázaro pueda sentarse a la misma mesa que el rico (Lc 16, 19-31)" (47)

\title{
2.3. El estado social de derecho en las constituciones contemporáneas
}

Puede decirse que el estado social de derecho se vislumbra con cierta claridad desde las constituciones mexicana de 1917 (sobretodo en sus arts. 27 y 123 ) y alemana de 1919 (en sus arts. 151, apartado $1^{\circ}, 153$, apartado final, y 161). Pero sólo después de la segunda guerra mundial se lo comienza a consagrar directa y explícitamente ${ }^{159}$.

156 TERCERA CONFERENCIA GENERAL DEL EPISCOPADO LATINOAMERICANO, La Evangelización en el presente y en el futuro de América Latina (Conferencia Episcopal de Chile, Santiago de Chile 1989).

VILLEGAS, BELTRAN. "Bienaventuranzas y teología de la liberación", en Diálogo en torno a la teología de la liberación

(llades-Salesiana, Santiago de Chile 1986), pp. 45-46. Este autor añade que "en la tríada original, cuando se habla de pobres, sufridos y hambrientos, no se piensa en tres grupos distintos, sino que estos tres nombres designan más bien tres caracteristicas del mismo grupo social: el de los marginados de la sociedad... Pues bien, a este desecho de la sociedad, a estos indigentes que nunca comen hasta hartarse y que andan con el alma en un hilo, Jesús los llama bienaventurados a causa del acercamiento del reinado de Dios, ya que éste significará el fin de su situación de 'humillados y ofendidos'. En otras palabras, los que, como consecuencia del 'orden' imperante en el mundo presente, carecen de los bienes más necesarios y llevan por eso una existencia disminuida, son los que primero tienen que alegrarse del acercamiento del reinado de Dios, ya que él significa también el acercamiento de su propia liberación y de su participación en los beneficios del reinado de Dios. Al proclamar a los pobres bienaventurados a causa del acercamiento del reinado de Dios, Jesús está denunciando la pobreza como uno de los males que impiden que este mundo pueda considerarse como una realización del reinado de Dios o como una expresión de su voluntad; y por consiguiente, como una situación llamada a desaparecer al llegar el reinado de Dios y al cumplirse su voluntad en la Tierra como se cumple en el Cielo" (p. 46). Además. "hay que dejar muy en claro que el fundamento último de la misteriosa economia que privilegia a los pobres está en el 'carácter' de Dios. En ella se revela Dios al mismo tiempo como justo (al reaccionar contra la injusticia objetiva de la pobreza de los pobres) y como Padre, es decir, como Gracia y Ternura, como Amor misericordioso y gratuito. El privilegio evangélico de los pobres no se basa, pues, en una visión moralísticamente idilica de los pobres, ni es de 158 raigambre sociológica, sino 'teo -lógica" (p. 47).

${ }^{158}$ PABLO VI (n. 151).

159 VANOSSI, JORGE REINALDO (n. 75), pp. 25-27 y 285-292; COLOMER VIADEL, ANTONIO (n. 42), pp. 104-105; BELMAR, FRANCISCO (n. 93), pp. 238-239. 
En lo que sigue, se describirá sumariamente la consagración constitucional del estado social de derecho en Alemania y en España, dos de los casos más conocidos en esta materia.

\subsubsection{El caso alemán}

La Ley Fundamental de Bonn, de 1949, se refiere al estado social de derecho en dos artículos: en el apartado $1^{\circ} \mathrm{del} 20$, que dice que "la República Federal de Alemania es un Estado federal, democrático y social", y en el comienzo del apartado $1^{\circ}$ del art. 28 , que señala que "el orden constitucional de los Länder deberá responder a los principios del Estado de Derecho republicano, democrático y social expresados en la presente Ley Fundamental". Por el lado de los derechos fundamentales, no aparecen los llamados derechos sociales, salvo en lo dispuesto en los arts. 14 y 15 -que aluden a la propiedad y a su función social, y a la posibilidad de socializar tierra y suelo, riquezas naturales y medios de producción, respectivamente-. Además, el apartado 1 del art. 20 dispone que "todos tienen derecho al libre desenvolvimiento de su personalidad siempre que no vulneren los derechos de otro ni atenten al orden constitucional o a la ley moral". Y el apartado 3 del art. 79 sienta la inadmisibilidad de cualquiera modificación del art. 20.

Siguiendo a Parejo, pueden distinguirse tres momentos en la inteligencia de estos preceptos por parte de los autores alemanes.

En un primer momento, se enfrentan dos interpretaciones polares: una que atribuye una contundente validez a las cláusulas que consagran el estado social, y otra que se la niega completamente. Así, en 1949 Ipsen afirma que la cláusula del estado social comporta la responsabilidad y la competencia del estado para la configuración del orden social. Además, importa que los derechos fundamentales tienen una función social. $Y$, aunque limitada por la recepción del estado de derecho, esta cláusula debe ser interpretada de modo que sea efectiva. Contra esta interpretación, Grewe asegura que la cláusula del estado social carece de contenido y sustancia ${ }^{160}$.

Un segundo momento se mueve dentro del ámbito de las reflexiones de Ipsen, en cuanto que el estado social es un principio constitucional efectivo, es decir, de inmediata aplicación (aunque requiera de precisiones). La doctrina y el Tribunal Constitucional Federal comienzan a concordar en esto. Aquí concurren las ideas de Forsthoff y Bachof.

Forsthoff parte reconociendo que el estado moderno es social, puesto que garantiza la subsistencia a través de prestaciones y redistribución de la riqueza. De ahí que el estado maneje la moneda, controle la balanza de pagos, influya en la formación de precios de bienes de consumo normal y tenga una política tributaria. Esto se refleja en una serie de leyes - de seguridad social, del trabajo, etc.- y en las funciones del estado ${ }^{161}$. "De esta manera el hombre moderno no solamente vive en el Estado, sino del Estado... Ningún Estado moderno puede defraudar tales esperanzas sin amenazar con ello su propia existencia; por eso mismo tiene que enfrentarlas y ser un Estado so-

\footnotetext{
160

PAREJO, LUCIANO (n. 99), pp. 34-35.

${ }^{161}$ FORSTHOFF, ERNST, "Problemas constitucionales del Estado social", en El Estado social (n. 84), pp. 45-46 y 49-50
} 
cial" ${ }^{162}$. La cuestión, empero, surge con la consagración conjunta que hace la Ley Fundamental de Bonn del estado de derecho y el estado social, dos tipos estatales muy diversos -en opinión de Forsthoff-. La tesis de Forsthoff es la siguiente: "... el Estado de Derecho y el Estado Social no son compatibles 'en el plano constitucional' y la Ley Fundamental debe ser entendida primariamente como una constitución liberal "163. Hay una "... extraordinaria consistencia del Estado de Derecho frente a los intentos de introducir en él contenidos sociales... La historia de la administración ofrece, en cambio, una imagen completamente diferente en el transcurso de los últimos cien años... La administración se enfrenta con la realidad social del modo más directo y no puede esquivar sus exigencias. Casi todas las instituciones de nuestro Derecho público, que han transformado al Estado en un Estado social, son obra de la legislación y de la administración. Se han creado y existen desde hace años o decenios sin que las constituciones hayan tomado nota de ello. No es, pues, por el ámbito constitucional, sino por el de la administración por donde el Estado social ha penetrado en la teoría del Derecho público"1 $^{164}$. "Estas consideraciones nos conducen directamente a la problemática del Estado social de Derecho. Las garantías jurídico-sociales no consisten primariamente en limitaciones, sino en participación. Libertad y participación son nociones cardinales que configuran hoy las relaciones del individuo en el Estado... La libertad garantizada mediante una limitación hace referencia a un Estado que se traza límites a sí mísmo, deja pues al individuo en la situación social que tiene; por consiguiente, también al Estado que, en esa relación de libertad, mantiene el 'statu quo'. La participación como derecho y pretensión supone un Estado que ayuda, reparte, distribuye y adjudica, que no abandona al individuo en su situación social sino que acude en su ayuda mediante subsidios. Tal es el Estado social" ${ }^{165}$. Esto reafirma que la constitución sólo debe consagrar al estado de derecho. "A diferencia de las libertades, los derechos de participación [del estado social] carecen de un contenido constante, susceptible de reglamentación previa. Necesitan modulación y diferenciación puesto que sólo son razonables en el marco de lo oportuno, necesario y posible, según el caso concreto. La fijación de este patrón debe ser abandonado a la ley y a los actos administrativos que desarrollan ésta. Por esta razón derechos sociales tales como el derecho al trabajo, a la seguridad social, a la enseñanza, educación, protección de la familia, maternidad o juventud, no se pueden captar en una norma abstracta, susceptible de aplicación [como debe ser la norma constitucional]"166

Entonces, ¿qué significa 'social' en los arts. 20 y 28 de la Ley Fundamental? "Puede ser empleado en su sentido polémico originario, y con ello se significa un repartimiento más adecuado y justo de los bienes del que existe en la realidad o del que existiría según el decurso libre de las cosas sin influencia del Estado. Pero social puede ser también en un sentido no polémico, referido a lo que ya existe y significar así instituciones, conceptos y normas jurídicas que la evolución social ha llevado a un mejor repartimiento de bienes y constituyen hoy parte integrante de nuestro ordenamiento

\footnotetext{
${ }^{162}$ FORSTHOFF, ERNST (n. 161), pp. 50 y 53.

${ }^{163}$ FORSTHOFF, ERNST (n. 161), p. 45-46.

${ }^{164}$ FORSTHOFF, ERNST, "Concepto y esencia del Estado social de Derecho", en El Estado social (n. 84), pp. 77-78.

${ }^{165}$ FORSTHOFF, ERNST (n. 164), p. 86

${ }^{166}$ FORSTHOFF, ERNST (n. 164), pp. 87-88.
} 
jurídico"167. En ambos sentidos, 'social' es un término vago y que posibilita transgresiones del estado de derecho. "La fórmula de 'Estado Social de Derecho' no es un concepto jurídico en el sentido de que designe una categoría especial del Estado de Derecho, con características específicas y contenido material propio. De esta fórmula no pueden deducirse derechos ni deberes concretos, ni instituciones (como la cogestión) ${ }^{168}$. Por ello es por lo que "la opción en favor del Estado social carece particularmente de un significado institucional. No afecta a las líneas estructurales de la Constitución de la República Federal. Esta sigue estando caracterizada plenamente con la noción de Estado de Derecho. Estado de Derecho y Estado social no se fusionan, por lo tanto, en el plano constitucional. Es sólo cuando entran en relación Constitución, legislación y administración que se relacionan también Estado de Derecho y Estado social..." ${ }^{169}$. Parejo dice "... que para Forsthoff Estado de Derecho y Estado social son principios distintos, no reductibles a uno nuevo y que están en relación dialéctica... No obstante, en esa relación dialéctica, los principios no están en pie de igualdad, al tener superior rango el del Estado de Derecho. De ahí que el Estado social quede reducido a lo que en cada momento sea realizado efectivamente como tal por el legislador ${ }^{170}$.

Doehring sigue a Forsthoff. Para él, el estado de derecho y el estado social constituyen principios contradictorios ${ }^{171}$. "... Si se acepta como tarea del Estado de Derecho no solamente el establecimiento de un 'procedimiento que garantice la seguridad jurídica', sino la protección de los derechos materiales adquiridos en su sustancia, así como también impedir su expolio, y por otro lado se coloca como taręa del 'Estado social de Derecho la repartición' de bienes materiales para conseguir a través de ella la igualdad, la conclusión es que ambos fines son en sí contradictorios"172. Entonces, "o bien se decide reconocer en la doctrina y en la práctica la primacía del Estado de Derecho que garantiza la justicia material y procesal sobre el Estado social, abandonando a la legislación y acción administrativa la puesta en práctica del Estado social [así Forsthoff], o se llega mediante el reconocimiento de la paridad entre el Estado de Derecho y el Estado Social a una 'justicia del caso concreto', imprevisible, apoyada en el llamado contraste de intereses [así alguna jurisprudencia]. Incluso se observan tendencias a la interpretación constitucional que tienden a hacer prevalecer el principio social sobre el del Estado de Derecho, tal y como se manifiesta cuando se habla del 'mandato' de la Ley Fundamental; esto es, del perfeccionamiento del... 'socialismo democrático'11 173 . Doehring, por cierto, reconoce primacía al principio del estado de derecho, en vista de la decisión constitucional en favor de la libertad individual, que hace que la igualdad sea el derecho de los ciudadanos a ser libres del mismo modo ${ }^{174}$.

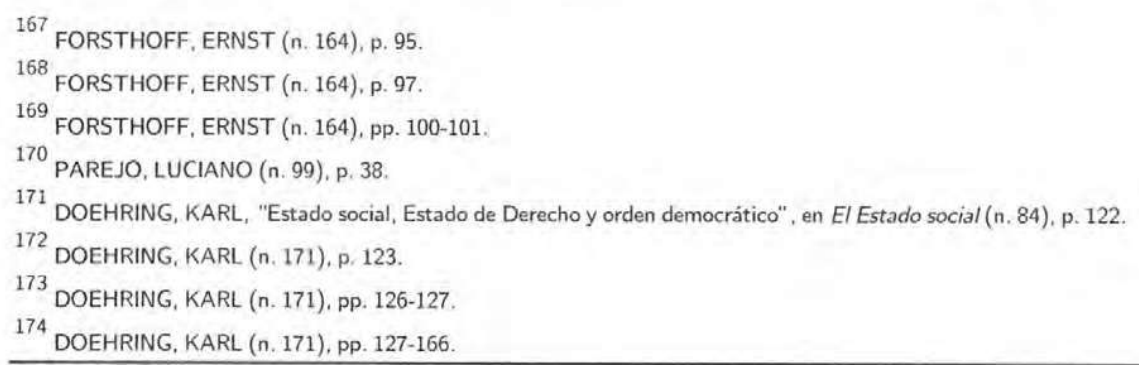


Bachof, al contrario de Forsthoff, cree que el estado social implica un mandato de configuración social, de consecución y conservación de la justicia social: por tanto, es un estado de derecho con un contenido material. Aquel mandato se dirige primariamente al legislador; para la administración y jurisdicción es una directriz de apreciación e interpretación. Ahora, aunque estado de derecho y estado social se realizan en la constitución y en normas infraconstitucionales, el primero tiene su centro de gravedad en aquélla y el segundo en éstas. Además, ambos principios son autónomos sólo en medida limitada. Enseguida, la vinculación social de la libertad -propia del estado social- es cosa bien distinta de una planificación total y coactiva de la sociedad ${ }^{175}$. "Para Bachof, pues, los principios social y de Derecho predicados respecto del Estado son de igual rango (aunque de distinta textura en su realización en el ordenamiento), pudiendo afirmarse su autonomía sólo en medida limitada. De ahí que el Estado social de Derecho no sea otra cosa que un sistema de equilibrio entre los dos principios, dosificados en el ordenamiento estatal ${ }^{176}$.

En un tercer momento, hay un alejamiento de las ideas de Forsthoff, ya que la mayoría de los autores considera que la Constitución no sólo proclama conjuntamente los principios social, de derecho y democrático, sino que les da el mismo valor: no cabe, pues, jerarquización alguna. Por medio del equilibrio o de la síntesis de dichos principios, ha de decirse que el estado social de derecho es un nuevo tipo de estado, diverso del liberal y del totalitario ${ }^{177}$. Su contenido mínimo descansa en estos puntos:

- el estado está obligado a actuar positivamente sobre el orden social en su globalidad, lo que constituye una precisa responsabilidad del estado (que recae sobre los bienes materiales y culturales); y

- no hay un 'modelo' de orden social querido por la constitución, pues -como dice Abendroth- la determinación del principio social debe realizarse democráticamente y a través de las formas del estado de derecho ${ }^{178}$.

Así, Fechner dice que "el Estado social de Derecho, en tanto que Estado de Derecho, no puede ser totalitario, pero en cuanto Estado social tampoco puede ser liberal. Consecuentemente, ha de admitirse que el Estado social de Derecho, al excluir esas dos posibilidades, está 'formulado en función de una tercera' (que no sea ni la una ni la otra) 11179 .

Para Abendroth, "el principio social no sólo abre la posibilidad o permite simplemente intervenciones estatales esporádicas o concretas a fin de corregir disfunciones en el orden social, sino que -y esto es lo decisivo- 'pone a disposición de la formación de la voluntad política del pueblo el propio orden social como tal'... Quiere esto decir que el alcance propio del elemento social del complejo Estado proclamado por la Constitución radica en que el 'pensamiento democrático se proyecta, a través de las formas propias del Estado de Derecho, en el orden social y económico'. Consecuentemente, el

\footnotetext{
${ }^{175}$ PAREJO, LUCIANO (n. 99), p. 39.

176 PAREJO, LUCIANO (n. 99), p. 39

177 PAREJO, LUCIANO (n. 99), pp. 49-50.

${ }^{178}$ PAREJO, LUCIANO (n. 99), pp. 50-51.

${ }^{179}$ PAREJO, LUCIANO (n. 99), p. 42.
} 
Estado proclamado en la Constitución es 'un nuevo Estado', una unidad integrada por una diversidad de principios, actuantes en esa unidad en la forma indicada" ${ }^{180}$. cuanto a:

Huber establece una serie de diferencias entre el estado de derecho y el social en

- bienes protegidos: el estado de derecho protege la vida, la libertad y la propiedad; el estado social protege la existencia, el pleno empleo y el trabajo de los marginados;

- extención del poder estatal: el estado de derecho limita dicha extención respecto de la libertad y de la propiedad; el estado social más bien la exige; y

- orden económico: el estado de derecho funda la empresa en la propiedad y el mercado libre; el estado social destaca la función social del mercado y las intervenciones estatales.

Pese a estas diferencias, agrega Huber, la constitución exige la síntesis de estos principios en el estado social de derecho, sin dar primacía a ninguno, pues cada uno precisa del otro $^{181}$.

Schneider argumenta que "el Estado asume hoy nuevas tareas en el ámbito de la asistencia social, en el de las condiciones generales de la existencia y en el fomento de las condiciones laborales y económicas, tareas cuyo adecuado cumplimiento es prerrequisito de posibilidad de dicha vida individual y social. La Ley Fundamental expresa su reconocimiento de estos condicionamientos del moderno desarrollo técnico y económico, con la fórmula del 'Estado social de Derecho', mediante la cual se encomienda a los órganos estatales la misión de conseguir, ya en el presente, una relativa compensación de los diversos intereses, aspiraciones y necesidades según criterios inspirados en la justicia social, y prescindiendo de todo igualitarismo utopista proyectado hacia el futuro. De ahí que, desde la perspectiva de la Ley Fundamental, rija para la acción política el principio rector de la 'democracia social a través de las formas del Estado de Derecho' [en palabras del Tribunal Constitucional Federal]" ${ }^{182}$.

En igual sentido opinan Maunz, Klein, Dürig, Scheuner y Gerber ${ }^{183}$.

Más concretamente -y siguiendo al Tribunal Constitucional Federal-, el carácter social del estado ha sido determinado jurídicamente de dos maneras:

a) Como vinculación social del estado (sobretodo del legislador). Esto se manifiesta de tres maneras: social;

- interpretándose la legislación vigente del modo más favorable a la igualdad

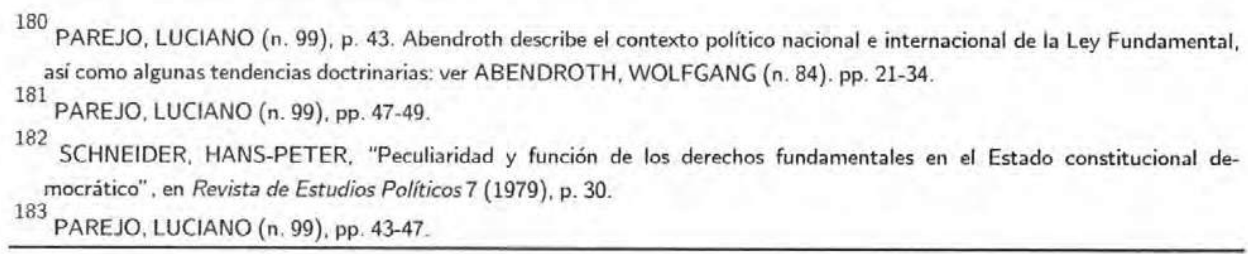


- justificándose leyes que, de otra manera, atentarían contra la igualdad; así, se admite el trato diferenciado de situaciones (como, por ejemplo, en las prestaciones públicas o las cargas tributarias); y

- concretándose límites al legislador a través de la declaración de inconstitucionalidad de las leyes que desobedezcan el principio social.

Hesse formuló la teoría de la irreversibilidad. La constitución no otorga un contenido sustantivo a la vinculación social del estado; pese a ello, cuando el legislador o el administrador regulan esta vinculación, toda ley o reglamento posterior que afecte el contenido de dichas regulaciones es inconstitucional. O sea, las conquistas sociales alcanzadas son irreversibles.

Varios autores se opusieron a dicha teoría, considerando los recursos económicos de los que dispone efectivamente el estado. Es difícil, si no imposible, mantener durante épocas económicas críticas las prestaciones creadas en las épocas de bonanza. Por esto mismo, la constitución no reconoce derechos de carácter social.

Ante estos argumentos, Hesse matizó su teoría: la irreversibilidad sólo corresponde al núcleo esencial de las conquistas sociales. Así, esta irreversibilidad restingida podría dar lugar a verdaderos derechos subjetivos frente al legislador y frente al administrador. Pero, en general, tiende a creerse que la vinculación social del estado no origina derechos subjetivos ${ }^{184}$.

b) Como referencia social de los derechos fundamentales. La constitución, abandonando el ideario liberal, aborda los derechos fundamentales no tanto desde el punto de vista de su garantía jurídica como desde el de su realización efectiva. Aunque no se consagran derechos propiamente sociales, el estado tiene la responsabilidad de procurar el efectivo disfrute de los derechos fundamentales al mayor número posible de personas. Esto tiene, cuando menos, dos consecuencias:

- la fortificación de la protección de los socialmente débiles y el debilitamiento de la protección de los socialmente poderosos. En cuanto a aquéllos, el estado debe tutela, sobretodo judicial; respecto a éstos, el estado debe impedir que su libertad perjudique a otros. El estado debe actuar compensatoriamente; $y$

- la inconstitucionalidad de una interpretación puramente formalista del principio de igualdad.

Es problemático, sí, el intento de construir derechos de participación en las prestaciones sociales, bajo la forma de derechos subjetivos frente al estado: sería un derecho a la efectiva garantía de la posición que un derecho fundamental atribuye. El Tribunal Constitucional Federal no ha cerrado el paso a tal posibilidad, más aún cuando un derecho fundamental no es sólo protección frente al poder estatal, sino también garantía por parte del estado. Pero se oponen dos objeciones a esta construcción. Una, que es muy diferente la garantía tradicional de un derecho que un deber estatal positivo de hacer, pues mientras la primera se agota con su positivación, la segunda precisa de actos materiales del estado que escapan del ámbito del derecho. Y la otra es que es contraproducente garantizar un elenco de derechos que, eventualmente, pueden ser imposibles de cumplir, ya que dependen de los medios con que cuenta el estado.

184 PAREJO, LUCIANO (n. 99), pp. 52-55. 
Entonces, se tiende a reconocer que las aspiraciones de prestaciones sociales deben satisfacerse primariamente en las instancias representativas de la voluntad popular y no en procesos judiciales ${ }^{185}$.

Ahora bien -y aquí se sigue a Schneider-, según el apartado 3 del art. 1 los derechos fundamentales constituyen derecho directamente aplicable, motivo por el cual vinculan a los poderes legislativo, ejecutivo y judicial. "... Según esto, el legislador no puede aprobar ninguna ley, el poder ejecutivo no puede decretar ningún acto administrativo y la jurisdicción no puede fallar ninguna sentencia que sean incompatibles con las garantías de los derechos fundamentales" ${ }^{186}$. ¿Qué efectos tiene esto para el estado social?

Subjetivamente, esto implica que el contenido de los derechos fundamentales "... debe consistir en 'derechos a prestaciones' sociales que comprenden... tanto una puesta en marcha de la actividad general del Estado, cuanto la pretensión de aprovechar servicios ya prestados o instalaciones ya existentes. En lo que hace a la primera alternativa, cabría tal vez pensar... en el derecho del aseguramiento del mínimo vital por parte del Estado... Para la segunda alternativa, presumiblemente podría derivarse del derecho a la libre elección de profesión-consagrado por el art. 12 de la Ley Fundamental- una pretensión del ciudadano en situación de paro a beneficiarse del seguro de desempleo (no así a obtener determinado puesto de trabajo), y quizá a reclamar una formación profesional en otra especialidad" ${ }^{187}$.

"En sentido objetivo, los derechos fundamentales en vigencia bajo las condiciones del Estado de prestaciones sociales cristalizan como 'directrices constitucionales' y 'reglas de actuación legislativa', de las cuales se desprende la obligación -no accionable, pero sí jurídicamente vinculante- de una determinada puesta en marcha de la actividad estatal. De forma semejante a los mandatos explícitos dirigidos al legislador por la Ley Fundamental (véase, por ejemplo, art. 6 , apartado $5^{\circ}$ ), el Tribunal Constitucional sólo puede, en un primer momento, emitir una ordenanza de ejecución; si el legislador continúa inactivo, puede censurar su pasividad y fijarle un plazo reglamentario, y, finalmente, declarar al legislador incurso en violación constitucional. El Tribunal no dispone de otras posibilidades ejecutorias, teniendo en cuenta además que la sanción de una ley depende, en última instancia, de la existencia de determinadas mayorías políticas" ${ }^{186}$.

Hasta acá la constitución alemana.

\subsubsection{El caso español}

La Constitución Española, de 1978, comienza con un preámbulo, que en lo que interesa dice: "la Nación española, deseando establecer la justicia, la libertad y la seguridad y promover el bien de cuantos la integran, en uso de su soberanía, proclama su voluntad de:

\footnotetext{
${ }^{185}$ PAREJO, LUCIANO (n. 99), pp. 56-59.

${ }^{186}$ SCHNEIDER, HANS-PETER (n. 182), p. 20.

${ }^{187}$ SCHNEIDER, HANS-PETER (n. 182), pp. 30-31.

${ }^{188}$ SCHNEIDER, HANS-PETER (n. 182), p. 32.
} 
Garantizar la convivencia democrática dentro de la Constitución y de las leyes conforme a un orden económico y social justo.

... Promover el progreso de la cultura y de la economía para asegurar a todos una digna calidad de vida.

\section{Establecer una sociedad democrática avanzada...".}

El apartado $1^{\circ}$ del art. 1 dice que "España se constituye en un Estado social y democrático de Derecho, que propugna como valores superiores de su ordenamiento jurídico la libertad, la justicia, la igualdad y el pluralismo político". El art. 7 ampara a los sindicatos de trabajadores y a las asociaciones empresariales. El art. 9, que en sus apartados $1^{\circ}$ y $3^{\circ}$ consagra diversos elementos del estado de derecho, señala en su apartado $2^{\circ}$ : "corresponde a los poderes públicos promover las condiciones para que la libertad y la igualdad del individuo y de los grupos en que se integra sean reales y efectivas; remover los obstáculos que impidan o dificulten su plenitud y facilitar la participación de todos los ciudadanos en la vida política, económica, cultural y social".

En el Título I-de los derechos y deberes fundamentales-, interesan los capítulos segundo -derechos y libertades- y tercero -de los principios rectores de la política social y económica-. Pero antes de los capítulos, está el art. 10, cuyo apartado $1^{\circ}$ dice: "la dignidad de la persona, los derechos inviolables que le son inherentes, el libre desarrollo de la personalidad, el respeto a la ley y a los derechos de los demás son fundamento del orden político y de la paz social", mientras que su apartado $2^{\circ}$ advierte que las normas constitucionales relativas a los derechos fundamentales deben interpretarse de acuerdo a la Declaración Universal de Derechos Humanos. En el capítulo segundo, antes de la división en secciones, aparece el art. 14: "los españoles son iguales ante la ley, sin que pueda prevalecer discriminación alguna por razón de nacimiento, raza, sexo, religión, opinión o cualquier otra condición o circunstancia personal o social".

El art. 27, en la primera sección de este capítulo -de los derechos fundamentales y de las libertades públicas-, sienta el derecho a la educación, y el 28 reconoce el derecho a la libre sindicación y a la huelga. En la segunda sección-de los derechos y deberes de los ciudadanos-, el art. 31 establece, por un lado, el deber de la tributación justa, y, por el otro, que "el gasto público realizará una asignación equitativa de los recursos públicos"; el art. 33 reconoce el derecho a la propiedad privada y su correspondiente función social; el 35 señala el derecho al trabajo; el 37 garantiza el derecho a la negociación colectiva laboral y a la adopción de medidas de conflicto colectivo; y el art. 38. al fin, establece lo siguiente: "se reconoce la libertad de empresa en el marco de la economía de mercado. Los poderes públicos garantizan y protegen su ejercicio y la defensa de la productividad, de acuerdo con las exigencias de la economía general y, en su caso, de la planificación".

En el capítulo tercero, se reconocen diversos derechos -o, más bien, principios de la política social y económica-: derecho a la protección pública de la familia y de sus distintos miembros (art. 39), a que los poderes públicos mantengan un régimen público de seguridad social (art. 41), a la protección de la salud (art. 43), al acceso a la cultura (art. 44), al disfrute y protección del ambiente (art. 45), a la vivienda (art. 47), y otros más. Dentro de estos principios, está el del apartado $1^{\circ}$ del art. 40: "los poderes públicos promoverán las condiciones favorables para el progreso social y económico y para una distribución de la renta regional y personal más equitativa, en el marco de una 
política de estabilidad económica. De manera especial realizarán una política orientada al pleno empleo".

El capítulo cuarto - de las garantías de las libertades y derechos fundamentalesdiferencia las garantías del capítulo segundo de las del tercero. Así, el apartado 1 del art. 53 dice que "los derechos y libertades reconocidos en el Capítulo segundo del presente Título vinculan a todos los poderes públicos. Sólo por ley, que en todo caso deberá respetar su contenido esencial, podrá regularse el ejercicio de tales derechos y libertades que se tutelarán de acuerdo con lo previsto en el artículo 161, 1, a) [que alude al recurso de inconstitucionalidad ante el Tribunal Constitucional]". Por su parte, el apartado 2 dice: "cualquier ciudadano podrá recabar la tutela de las libertades y derechos reconocidos en el artículo 14 y la Sección 1a. del Capítulo Segundo ante los Tribunales ordinarios por un procedimiento basado en los principios de preferencia y sumariedad y, en su caso, a través del recurso de amparo ante el Tribunal Constitucional...". Y el apartado 3 del art. 53, en cambio, señala: "el reconocimiento, el respeto y la protección de los principios reconocidos en el Capítulo Tercero, informará la legislación positiva, la práctica judicial y la actuación de los poderes públicos. Sólo podrán ser alegados ante la Jurisdicción ordinaria de acuerdo con lo que dispongan las leyes que los desarrollen".

EI Título VII trata de economía y hacienda. Su art. 128 dice, en su apartado 1 , que toda la riqueza del país está subordinada al interés general; y en el apartado 2 añade: "se reconoce la iniciativa pública en la actividad económica. Mediante ley se podrá reservar al sector público recursos o servicios esenciales...". El apartado 2 del art. 129 encomienda a los poderes públicos promover la participación en la empresa y, en especial, facilitar el acceso de los trabajadores a la propiedad de los medios productivos. EI art. 130, en tanto, entrega a los poderes públicos la atención por la modernización y desarrollo de los sectores económicos, "... a fin de equiparar el nivel de vida de todos los españoles". El 131, en su apartado 1, establece: "el Estado, mediante ley, podrá planificar la actividad económica general para atender a las necesidades colectivas, equilibrar y armonizar el desarrollo regional y sectorial y estimular el crecimiento de la renta y de la riqueza y su más justa distribución".

Por último, en el Título $X$-de la forma constitucional-, el art. 168 señala que la revisión del Título Preliminar o de la sección 1a. del capítulo segundo del Título I, requiere de una alta mayoría.

Se revisarán, ahora, las opiniones de una serie de autores, sobretodo españoles, en torno al significado y a las implicancias que tiene el estado social de derecho consagrado en la constitución de 1978.

\section{¿Qué ideologías concurren en la constitución española?}

Gil dice que la ideología básica de la constitución es la liberal. Empero, hay elementos de las ideologías demócrata-cristiana y social-demócrata. En concreto, la idea del estado social de derecho y los principios rectores de la política social y económica refejan la influencia social-demócrata ${ }^{189}$.

${ }^{189}$ GIL, JUAN JOSE, "Las ideologías en la Constitución española de 1978", en Estudios sobre la Constitución española de 1978 (n.44). pp. 83-86. 
Lucas Verdú dice que en el texto constitucional hay dos facetas: "... una inspirada en la tradición iluminista-garantista, que cuadra con el Estado liberal de derecho [así, el preámbulo, los arts. 1,1; 9,2; 40,1 y 129,2] y otra que corresponde al Estado social y democrático de derecho afín a la socialización [así, los arts. 33; 37,2 y 38]"190.

Según Belmar, hay quienes creen que el concepto de derecho de la constitución es liberal. Otros, como Peces Barba, afirman que hay un concepto mixto de derecho, dentro del cual se recoge la tradición del socialismo democrático, prueba de lo cual es la potenciación de la participación ciudadana, la iniciativa económica y la planificación económica públicas, la limitación del derecho de propiedad privada, la subordinación de la riqueza nacional al interés general, la función promocional del derecho y la consagración de funciones estatales positivas para la satisfacción de los derechos sociales ${ }^{191}$.

¿Y qué decir de la fórmula estado social y democrático de derecho que recoge la constitución?

Belmar señala que el art. 1,1 se ubica dentro del ámbito del constitucionalismo social. "El texto inicial del artículo fue propuesto por el grupo socialista en el Parlamento con la siguiente fórmula: 'España se constituye como Estado Democrático de Derecho que propugna como valor superior de su ordenamiento jurídico la justicia en la libertad y la igualdad'. Por su parte el Sr. Fraga Iribarne, del partido Alinza Popular, propuso que se le añadiera a la fórmula el término social, a lo que se sumaron los representantes de la U.C.D. y de la minoría catalana. El término del pluralismo político fue aceptado por todos" ${ }^{192}$. Por otra parte, el estado social es de difícil interpretación, por cuanto es un concepto más político que jurídico. De modo que, para unos, representa el intento capitalista de responder a las exigencias -insatisfechas por el capitalismo clásico- de la sociedad contemporánea, y, para otros, comporta un tipo de estado diverso del liberal, en concreto, uno que hace las veces de transición hacia un estado socialista democrático ${ }^{193}$. Concluye Belmar que "... la fórmula consignada en el art. 1,1 es una cláusula orientadora de la constitución, que sirve de un auxilio para interpretar los restantes preceptos..., guardando siempre una armoniosa coherencia con los valores que el mismo precepto ... dice propugnar, y que son la libertad, la justicia, la igualdad y el pluralismo político" ${ }^{194}$

Pérez Luño, en 1979, calificó de incongruente el intento del art. 1,1 de aunar y conjugar en la definición del estado de derecho los principios social y democrático. El estado español, entonces, será social o democrático según la ideología de las fuerzas políticas mayoritarias. Lo correcto hubiera sido decir que el estado español es un estado social de derecho en transición al estado democrático de derecho ${ }^{195}$. Pero después, contra lo dicho en 1979, Pérez Luño comenzó a creer que los principios de unidad, coherencia y fuerza integradora de la constitución impiden calificar de incongruente al 1,1. Los principios social y democrático, por tanto, son interdependientes y poseen

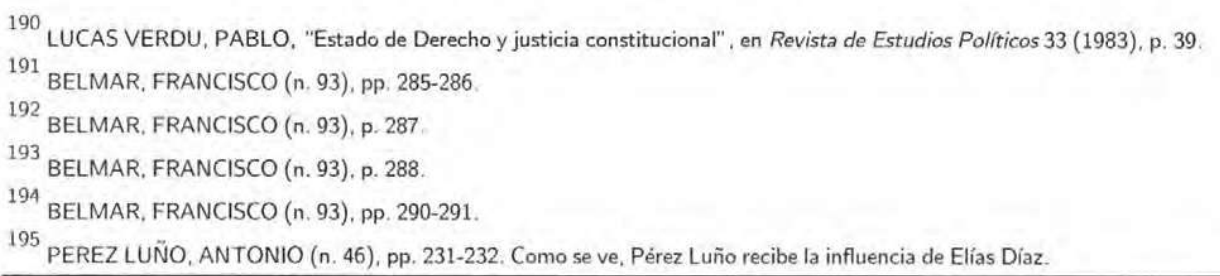


conexión interna ${ }^{196}$. Además, Pérez Luño polemiza con Elías Díaz. Díaz cree que el 1,1, cuando habla de un estado social y democrático y no al revés -como en Alemania-, se refiere a que el punto de partida es el estado social y a que el estado posible para la izquierda es el estado democrático (tal como él lo entiende). El estado democrático es el resumen jurídico y político del humanismo socialista, y en el plano socioeconómico implica la progresiva transformación de la propiedad privada de los medios de producción: tal es la interpretación auténtica del 1,1. Pero, replica Pérez Luño, la historia fidedigna de la constitución demuestra lo contrario. Además, la actual redacción del 1,1 demuestra la existencia de un consenso -entre diversas tendencias- en el constituyente. Por eso la interpretación de Díaz, representativa sólo de una tendencia, es inadmisible ${ }^{197}$.

Garrorena asegura que, "... trascendiendo a esas tres definiciones del Estado [social, democrático y de derecho], lo que el artículo 1 contiene es una definición en la que quedan implicados tres momentos lógicos, susceptibles, sí, de utilización independiente en cuanto no contradiga al conjunto, pero fuertemente integrados en la unidad que entre todos ellos componen. El Estado español es, en fin, cada una de esas tres calificaciones..., pero no es ninguna de ellas si no se la considera en función de las demás" ${ }^{198}$. Así, lo social y lo democrático del estado conducen a la democracia social, no sólo excluyente de sistemas autoritarios y totalitarios, sino también incluyente de una democracia económica y una democracia empresarial -e, incluso, susceptible de operar cambios sobre la versión liberal de la democracia política en aras de una mayor y mejor participación- ${ }^{199}$. Parejamente, la nota social y el sometimiento al derecho implican, por un lado, que un estado tan fuerte e intervencionista como el social no debe dejar de estar plenamente sujeto a la ley, y, por otro lado, que los derechos públicos subjetivos, además de estar socialmente vinculados, son tanto derechos frente al estado como derechos que operan directamente en las relaciones de los particulares ${ }^{200}$.

Parejo asevera que "el Estado democrático y social de Derecho representa... la aspiración de la consecución de una 'sociedad justa'..., es decir, de 'la justicia social como valor resultante de la libertad en la igualdad', habilitando y aun exigiendo para ello a los órganos estatales una actuación positiva de configuración social con vistas a la igualdad, pero desde el respeto a la libertad y en el contexto del pluralismo político..." ${ }^{201}$.

¿Cómo se puede interpretar la dimensión económica de la constitución?

Según Morisi, "nos topamos... con proposiciones que parecen contradictorias, al igual que las disposiciones en que se encuadra el artículo 38. Hay una especie de doble estratificación normativa en constante fricción. Por un lado, las 'normas de acción' que, siguiendo la estela del artículo 9, apartado 2, llegan al Capítulo III y a los artículos

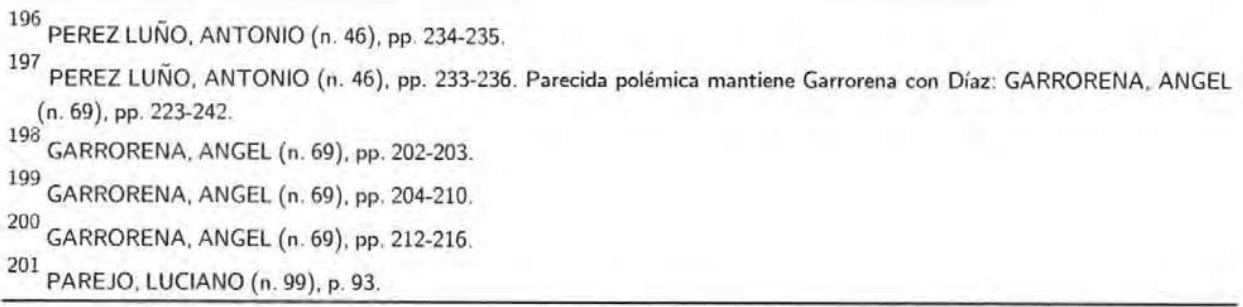


128, apartado 1,130 y 131, normas que podríamos denominar de cambio futurible y que imponen y permiten una acción estatal no solamente reguladora sino también conformadora de los procesos económicos. Por otro lado, el estrato de las normas que son intrínsecamente tales, que están dotadas de una estructura lógica de norma jurídica, las cuales, sobre la base de la discriminación garantista del artículo 53, apartado 1. respecto al 53, apartado 3 y sobre el vínculo del contenido esencial, confieren capacidad de resistencia a situaciones jurídicas subjetivas afectas al derecho de empresa (o de propiedad) frente a las decisiones del poder público aun legitimadas por las disposiciones del primer estrato" ${ }^{202}$

García Pelayo dice que "... la definición misma del Estado como Estado social significa añadir a las funciones estatales las destinadas a crear las condiciones vitales que ni el individuo, ni los grupos pueden asegurar por sí mismos, lo que implica ciertas intervenciones del Estado en el orden y proceso económicos. Pero, aparte de las intervenciones implícitas en la idea del Estado social, la Constitución contiene algunos preceptos destinados a concretizarlo, preceptos que al asignar a los poderes públicos ciertas funciones han de reconocerles tácita o expresamente las potestades para llevarlas a cabo (por ejemplo, el art. 9,2 encomienda a los poderes públicos 'promover las condiciones para que la libertad y la igualdad... sean efectivas', pero no le asigna una potestad concreta; en cambio, el art. 47 que establece que 'todos los españoles tienen derecho a disfrutar de una vivienda digna y adecuada', añade que para hacer efectivo este derecho los poderes públicos regularán la utilización del suelo 'de acuerdo con el interés general para impedir la especulación')" ${ }^{203}$. La competencia estatal para operar, de diversos modos, en el campo económico y, en especial, para planificar, se refleja en los arts. 40,$1 ; 45,2 ; 128 ; 130,1$ y $131,1^{204}$. Ahora bien, "... el sistema del que parte la normatividad constitucional es, desde el punto de vista económico, el sistema neocapitalista históricamente unido desde su nacimiento al 'Welfare State' o al Estado Social. Se trata -como es sabido- de un sistema sustentado sobre la economía de mercado, aunque con fuertes componentes oligopolistas, cuyos actores principales son las empresas privadas, pero en el que el Estado no sólo tiene la función de regulador jurídico, administrativo y económico del sistema, sino que simultáneamente tiene a su cargo una función social -hasta ahora considerada como parte esencial para la estabilidad del sistema- para cuya realización procede a redistribuir una parte importante del producto nacional en forma de distintas prestaciones, lo que contribuye a aumentar la demanda de bienes y servicios" ${ }^{205}$. "En conclusión: la Constitución parte de la infraestructura del sistema económico neocapitalista y establece unas normas bajo las cuales éste puede funcionar, pero ello no quiere decir que lo sancione, ni que la validez de dichas normas sea incompatible con modificaciones del mencionado sistema. En qué sentido vayan esas modificaciones será una cuestión a determinar por el sistema político bajo condicionamientos económico-coyunturales y de otra especie ${ }^{1206}$. Y en general, dichas modi-

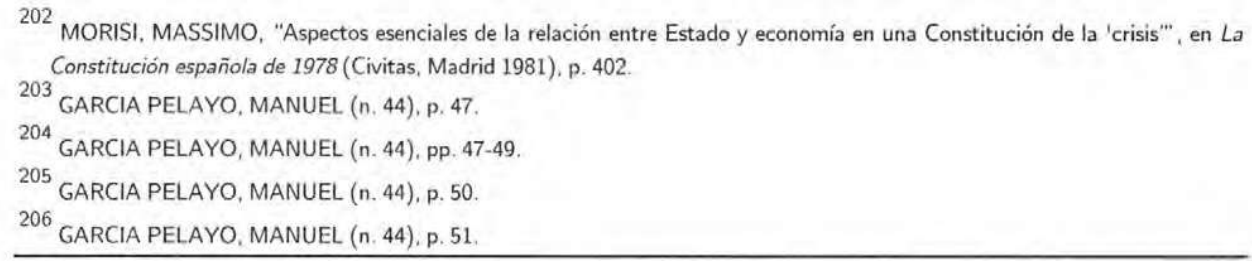


ficaciones podrían apuntar bien en dirección del socialismo democrático, bien hacia la consolidación capitalista ${ }^{207}$.

Basile cree que el estado social -en general y en la constitución española- es aquél donde "las estructuras económicas del capitalismo subsisten, pero se admiten intervenciones públicas más o menos amplias en función correctiva de los desequilibrios más graves que aquél implica" ${ }^{208}$. Empero, tiene en la constitución española otros sentidos, "... implícitos en la referencia a doctrinas de origen al menos en parte católico y en la garantía de los llamados 'derechos sociales', entendidos como 'derechos' de 'formaciones sociales' o 'comunidades' -en especial, la familia, instituciones religiosas y educativas, 'comunidades territoriales' y organizaciones de interés de categoría-" ${ }^{209}$.

"Así vemos que, con una claridad extraña en otros textos, la Constitución mantiene y garantiza explicitamente las estructuras del capitalismo. No encontramos aquí el uso de expresiones amplias y etéreas, como 'la iniciativa económica privada' del artículo 41 de la Constitución italiana. Encontramos, nítidamente, 'la libertad de empresa' y. para mejor claridad, 'en el marco de la economía de mercado' (art. 38). Y para derechos como la propiedad y la empresa, entre otros, encontramos que la ley, que debe regular su ejercicio, deberá respetar en todo caso 'su contenido esencial' (art. 53, apartado $1^{\circ}$ ).

Por otra parte, se declaran una serie de 'principios rectores de la política social y económica' (Título II, Capítulo III), se sanciona el 'derecho al trabajo' y a una retribución suficiente (art. 35) y se reconoce la exigencia de intervenciones públicas en la economía (art. 128) eventualmente con el método de la planificación global (arts. 38 y 131) y sin excluir tampoco, aunque con carácter excepcional, las colectivizaciones (art. 128 , apartado $2^{\circ}$ ). Pero, aparte del carácter eventual y en ocasiones extraordinario de estas intervenciones, para los 'derechos sociales' correspondientes no juega, como límite de las leyes que los regulen, el criterio del 'contenido esencial' que, como hemos visto, salvaguarda, en cambio, los pilares del capitalismo. De esta forma, resulta clara la función de esta normativa: permite corregir los más graves desequilibrios, con un efecto estabilizador, por tanto, de la estructura económica existente ${ }^{1210}$.

"Por otra parte, el principio de la 'dignidad de la persona' puede constituir por sí mismo el fundamento ideológico no sólo de los derechos de libertad civil -o sea, del Estado de Derecho-, no sólo de los derechos de participación -o sea, del Estado democrático-, sino también de las iniciativas de intervención pública para la corrección de los desequilibrios implícitos en el sistema social, a las que se alude cuando se habla de Estado social. Ciertamente, el principio de la 'dignidad de la persona' podría esconder incluso un potencial subversivo con relación a dicho sistema económico. $Y$ de ahí precisamente esa ambigüedad de fines a que aludía antes cuando hablaba de las derivaciones de la idea de Estado social en la Constitución española.

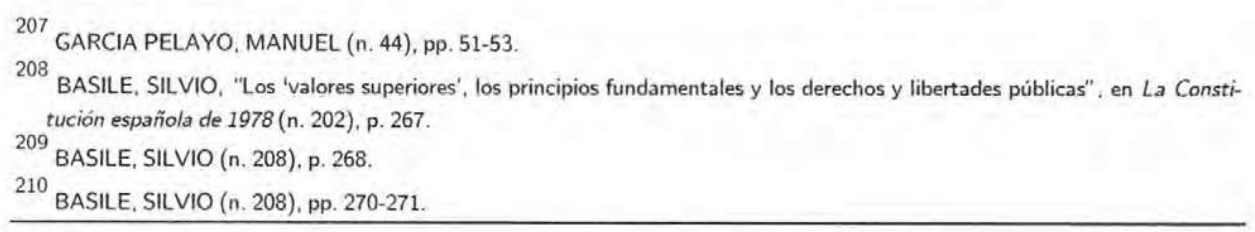


En todo caso, la exactitud de esta lectura del artículo 10 , apartado $1^{\circ}$, como fundamento ideológico del Estado social me parece confirmada, por un lado, por el resto del propio artículo $10 \mathrm{y}$, por otro, por el apartado $2^{\circ}$ del artículo $9^{\circ 1}{ }^{211}$.

En cuanto al apartado $2^{\circ} \mathrm{del}$ art. 9, "no es necesario insistir en el origen italiano de esta norma... porque, por encima de su forma, la sustancia del artículo $9^{\circ}$ español es idéntica a la sustancia del artículo $3^{\circ}$ italiano [que dice: "es misión de la república remover los obstáculos de orden económico y social que, limitando de hecho la libertad e igualdad de los ciudadanos, impidan el pleno desarrollo de la persona humana y la efectiva participación de todos los trabajadores en la organización política, económica y social del país"]; y si de éste se dijo que eleva 'la transformación de la sociedad a norma fundamental' porque exige 'la transformación de los presupuestos sociales que en el momento actual no son igualitarios', lo mismo, 'a rigore', se podría decir de aquél.

Sólo que mientras que la Constitución italiana, una vez declarado este principio, no establece realmente los instrumentos institucionales adecuados a la transformación, pero no opone tampoco obstáculos insuperables, la Constitución española es incluso demasiado clara en su deseo de mantener el sistema socio-económico existente, como hemos visto. En este cuadro, sin excluir la posibilidad de interpretaciones claramente progresistas.... el significado del artículo $9^{\circ}$, apartado $2^{\circ}$, no va más allá de la justificación del intervencionismo público corrector de desequilibrios en atención al mantenimiento del sistema económico actual y, por tanto, contra su propio tenor, no ha sido incluido en función de una efectiva transformación social" ${ }^{212}$.

El apartado $2^{\circ}$ del art. 10 -prosigue Basile- permitiría extender el área de libertad de los individuos, pues la Declaración Universal de los Derechos Humanos implica establecer una serie de condiciones económicas y sociales que salvaguarden la dignidad humana y posibiliten el ejercicio de los derechos del hombre. Esto reafirma que el apartado $1^{\circ}$ del art. 10 sirve de base al estado social ${ }^{213}$.

Y el art. 53 también da cuenta de la pretensión de conservar el actual sistema económico; es cosa de observar la distinta protección que se otorga a los derechos y libertades reconocidos en el Capítulo II del Título I y a los principios recogidos en el Capítulo III de dicho Título ${ }^{214}$

Por último, ¿qué resultados arroja una lectura global del estado social de derecho en la constitución española?

Belmar, en primer término, se pregunta si los principios establecidos en el capítulo III del Título I constituyen verdaderos derechos sociales. Al respecto, hay por lo menos dos respuestas. Peces Barba dice que dichos principios no son derechos sociales, sino meras normas programáticas sin un contenido jurídico preciso. Por el contrario, de

\footnotetext{
211 BASILE, SILVIO (n. 208), p. 275 .

212 BASILE, SILVIO (n. 208), pp. 275-276.

213 BASILE, SILVIO (n. 208), pp. 277-278.

${ }^{214}$ BASILE, SILVIO (n. 208), pp. 285-289.
} 
Castro Cid responde que sí son derechos sociales, pues más que normas programáticas, son reglas cuyo valor y eficacia son verdadera y plenamente jurídicos ${ }^{215}$.

En segundo término, Belmar inquiere por los alcances de la consagración del estado social en el art. 1,1 de la constitución española. Se trata, para él, de una cláusula general que no otorga derecho subjetivo alguno. Según Muñiz, el obligado por esta cláusula es el legislador, el cual puede elegir la manera, la oportunidad y el ritmo de cumplir este mandato. Sólo ante una total inactividad del legislador, constatada judicialmente, podría el ciudadano gozar de un derecho público subjetivo, el cual derivaría directamente del mandato social. $Y$ ante el administrador y el juzgador, esta cláusula sólo posee fuerza vinculante como pauta de ejecución e interpretación y, en particular, como directriz para el control de la discrecionalidad de los actos administrativos ${ }^{216}$.

Parejo apunta que, observando el art. 1,1, "... el orden estructural básico y definitorio del Estado no es simple por reductible a un único principio sustentador, sino complejo en tanto que integrado -simultáneamente y con idéntico rango- por los de sujeción al Derecho, carácter democrático y contenido social" ${ }^{217}$. Más aún: tales notas poseen consistencia jurídica y no mero valor político, ya que constituyen principios de derecho. El Tribunal Constitucional, junto con afirmar esto, ha señalado que la cláusula del estado social puede llegar a comportar deberes de hacer para los poderes públi$\cos$, ya que las tres notas a que se refiere el art. 1,1 son de tal relevancia, que su alteración se sujeta a un procedimiento extraordinario de reforma constitucional (de acuerdo al art. 168,1$)^{218}$.

Hay, cree Parejo, una importante correspondencia entre las tres notas del estado y los valores superiores del ordenamiento jurídico del art, 1,1 : así, a la democracia toca el pluralismo político, al estado de derecho, la libertad, y al estado social, la igualdad. El valor justicia, en estas correlaciones, es neutral. Todo esto se proyecta en el Título Preliminar, y así como democracia y pluralismo se reflejan en los arts. 6 y 7 y estado de derecho y libertad en los apartados $1^{\circ}$ y $3^{\circ}$ del art. 9 , el estado social y la igualdad encuentran su correlato en el $9,2^{219}$.

El Título I también da cuenta de estas notas y valores:

- los derechos y libertades de la sección 1a. del capítulo segundo gozan de máxima protección. Siendo verdaderos derechos de libertad o de la personalidad, en ellos prima la garantía jurídica, $Y$ pueden ser reconducidos al art. 9,3, al valor 'libertad' y a la nota 'estado de derecho';

- los derechos y deberes de la sección 2a. del capítulo segundo disfrutan de mediana protección. Constituyendo derechos sociales ligados a la personalidad, hay en ellos un equilibrio entre la garantía jurídica y la intervención estatal. Y pueden ser reconducidos tanto al estado de derecho como al estado social; y

\footnotetext{
215 BELLMAR, FRANCISCO (n. 93); pp. 293-295.

${ }^{216}$ BELMAR, FRANCISCO (n. 93), pp. 297-298.

217 PAREJO, LUCIANO (n. 99), p. 62.

${ }^{218}$ PAREJO, LUCIANO (n. 99), pp. 62-65.

${ }^{219}$ PAREJO. LUCIANO (n. 99). pp. 65-68.
} 
- los principios del capítulo tercero gozan de mínima protección. Siendo derechos económicos y sociales, prima en ellos la intervención estatal. Y pueden ser reconducidos al 9,2, a la igualdad y al estado social ${ }^{220}$.

El art. 10 -fuera de los capítulos y secciones del Título I y fuera del ámbito del art. 53- resume la axiología del orden dogmático de la constitución en la dignidad de la persona como fundamento del orden político y de la paz social. El tenor de este artículo impide interpretar la dignidad en un sentido liberal-individualista ("... el respeto a la ley y a los derechos de los demás..."), más todavía cuanto que el art. 14 establece la exclusión de la discriminación incluso por circunstancias sociales. La primacía de la dignidad de la persona explica que los derechos más cercanos a la personalidad humana posean mayor eficacia que los derechos que se van alejando de dicho centro. Pero, como puede verse - $y$ así lo ha entendido el Tribunal Constitucional-, el Título I no responde tan sólo al estado de derecho, sino también al estado social ${ }^{221}$.

De las tres notas del estado español, la democracia no plantea problemas de compatibilidad con las otras dos. Entonces, ¿en qué relación están el estado de derecho y el estado social?

Por cierto, ambas notas están en un pie de igualdad. Aunque una se satisface sólo con garantías jurídicas y la otra requiere de actuaciones jurídicas y materiales, ello no introduce disparidad alguna, sino que solamente obliga a estipular diversos regímenes jurídicos para ambas. La antinomia entre estas notas se produce si se entiende al estado de derecho como se lo entendió en el siglo pasado, o sea, en términos rigurosamente liberales. Pero hace tiempo ya que cambiaron la sociedad, el estado y las ideas acerca del estado. Esto se refleja en la constitución española: la sociedad que en ella se constituye no es homogénea, sino plural -política y económicamente-; los principios que se recogen del estado de derecho están atravesados por la nota del estado social; la libertad constitucional no es la liberal, sino aquélla que está vinculada socialmente en virtud de su asentamiento en la dignidad de la persona (como se expresa en los arts. 10,$1 ; 9,2 ; 14 ; 33 ; 38 ; 128,1$ y 131 ) y de su conexión con la igualdad (como se ve en el art. 1,1). Entonces, los elementos del estado de derecho están al servicio de la axiología constitucional, no pudiendo ser entendidos de un modo puramente formal ${ }^{222}$.

El estado social es el estado "... como instrumento corrector, configurador y prestador en la vida social y económica -en definitiva, [se trata de] la total interpenetración del Estado y sociedad, de modo que la cuestión no se centra tanto en la defensa del ámbito de libertad propia frente al Estado cuanto en la exigencia a éste de la resolución positiva de problemas y conflictos sociales" 122 . Como ha dicho Abendroth, el estado social deja de creer en la justicia de la situación económica existente $y$, en un paso más, coloca dicha situación en manos del estado para que éste la configure de manera más justa. Así es como se aprecia al estado social en la constitución española

\footnotetext{
${ }^{220}$ PAREJO, LUCIANO (n. 99), pp. 68-70.

${ }^{221}$ PAREJO, LUCIANO (n. 99), pp. 71-73.

222 PAREJO, LUCIANO (n, 99), pp. 74-81.

${ }^{223}$ PAREJO, LUCIANO (n. 99), p. 82.
} 
(en los arts. 1,$1 ; 9,2 ; 30-38 ; 39-52$ y $128-136$ ) y así lo ha reafirmado el Tribunal Constitucional ${ }^{224}$. Más en concreto:

a) La constitución impulsa la intervención social del estado (en los arts. 1,1: 9,2; 10,$1 ; 14 ; 40 ; 130$ y 131, entre otros), pero impide la estatalización de la economía (como se aprecia en el 38 y el 128$)^{225}$.

Dentro de ese marco, los objetivos del estado social se sujetan a las disponibilidades económicas del estado. "El principio social, aunque fundado en un valor absoluto (la dignidad de la persona).... implica 'una pretensión de realización del mismo no inmediata y plena, sino relativa e históricamente factible'... Lo que no impide, sin embargo, que su validez y eficacia jurídicas sean constantes y determinadas, a saber, las referibles 'a la exigencia de la mayor igualdad real y efectiva de los ciudadanos posible en cada momento'..." 226 . Por eso, "el modelo económico y los derechos de contenido social quedan entregados por entero, por lo que hace a la precisa configuración de los mismos, al legislador ordinario, en tanto que instancia de representación democrática idónea... para actualizar el marco constitucional con la legitimación que le es propia" ${ }^{227}$.

b) Tal remisión al legislador no se le hace en blanco, sino por medio de unos principios rectores de la política social y económica (como se ve en los arts. 39-52), "... que juegan -cada uno en sus propios términos y según su específica modulación constitucional-como 'criterios materiales vinculantes para el legislador' o, en su caso, 'la Administración' '1"228.

Ahora bien, el deber de hacer que importa el estado social, ora creando condiciones, ora removiendo obstáculos, está fijado más precisamente en el art. 53,3:

- primero, toda nueva ley debe conformarse a los referidos principios, so pena de invalidez. Segundo, las leyes ya existentes deben interpretarse del modo más favorable a esos principios. Tercero, la actuación no normativa (sobretodo de la administración) ha de ceñirse a esos principios para ser válida. Con todo, es evidente que persiste una importante discrecionalidad a la hora de precisar los deberes de hacer de los poderes públicos $^{229}$.

- la legislación que desarrolla la constitución ha de cristalizar -de acuerdo a su propia materia- la nota del estado social, pudiendo incluso crear verdaderos derechos subjetivos. ¿Son irreversibles tales derechos sociales?

Sí, si están ya reconocidos por la constitución. Pero la respuesta es no, si ella no los reconoce. La ley no es pura ejecución de la constitución; ésta es un marco en el que el legislador desarrolla la configuración social con amplia libertad. Además, estos derechos sociales penden de la capacidad económica del estado en cada momento. Ense-

\footnotetext{
${ }^{224}$ PAREJO, LUCIANO (n. 99), p. 83.

225 PAREJO, LUCIANO (n. 99), pp. 85-86.

${ }^{226}$ PAREJO, LUCIANO (n. 99), p. 86.

227 PAREJO, LUCIANO (n. 99), pp. 86-87.

${ }^{228}$ PAREJO, LUCIANO (n. 99), p. 87.

${ }^{229}$ PAREJO, LUCIANO (n. 99), pp. 87-88.
} 
guida, la petrificación de los derechos sociales infringe la nota democrática, pues impide la alternancia en el poder de agrupaciones políticas con diversas posturas económicas. Y, por último, dicha petrificación fuerza al art. 53,3, el cual entrega a la ley ordinaria la eventual concreción, bajo la forma de derechos, de los aludidos principios: una ley ordinaria presente -que crea un derecho social- no puede vincular a una futura ley ordinaria -que lo suprime- ${ }^{230}$.

Terminado Parejo, se exponen finalmente las ideas de Garrorena:

a) Para él, indudablemente el estado social se proyecta en el articulado de la constitución. El mismo art. 1,1 remarca dicha nota del estado al proclamar como valor superior del ordenamiento jurídico a la igualdad; en igual sentido se ha expresado el Tribunal Constitucional ${ }^{231}$.

Enseguida, el art. 14 recoge el pricipio de igualdad, y el Tribunal Constitucional también se ha pronunciado a este respecto:

- ya no es posible entender el principio de igualdad en su escueta acepción liberal. En un estado social de derecho, el legislador debe diferenciar las situaciones distintas a través de su tratamiento diverso. Si allá igualdad es no diferenciación, acá es no discriminación ${ }^{232}$.

- el problema, entonces, radica en establecer cuándo una diferenciación es o no es discriminatoria. El criterio es que 'la igualdad es sólo violada si la desigualdad está desprovista de una justificación objetiva y razonable'. ¿Cómo se verifica esto? Comparando, en cada caso, la norma o acto discriminatorio, la norma general y la norma constitucional que prohíbe la discriminación; segundo, comprobando la existencia y licitud constitucional del fin que es el soporte del trato diferenciado; indagando, enseguida, cuál es el alcance del elemento común que haría ilegítima la diferencia; y estableciendo, por fin, el nexo de conexión lógico y proporcionado entre aquel fin y el régimen diferenciado. Ahora bien, en vista de que el Tribunal Constitucional emite pronunciamientos de constitucionalidad, no es de su incumbencia pronunciarse acerca de la calidad técnica o la oportunidad de la medida diferenciadora ${ }^{233}$.

Pero además del art. 14, también se hacen cargo de la igualdad la primera declaración del Preámbulo, el art, 40,1 y, sobretodo, el art. 9,2. El art. 9,2 no es sólo un complemento de la igualdad formal, ya que también es útil para una interpretación material de todo el articulado constitucional $y$, en general, de todo el ordenamiento jurídico. El art. 3,2 de la constitución italiana, que es su visible modelo, también es susceptible de tal interpretación, pero la Corte constitucional italiana se ha negado a ello. Sin embargo, hay diferencias entre ambos preceptos:

- el art. 3,1 italiano contiene la igualdad ante la ley, por lo que se ha tendido a una interpretación sólo conjunta y confundente de los dos apartados del art. 3.

\footnotetext{
${ }^{230}$ PAREJO, LUCIANO (n. 99), pp. 88-91.

231 GARRORENA, ANGEL (n. 69), pp. 48-49.

232 GARRORENA, ANGEL (n. 69), pp. 49-51.

${ }^{233}$ GARRORENA, ANGEL (n. 69), pp. 51-56.
} 
En el caso español, en cambio, los arts. 9,2 y 14 se ubican en Títulos diversos, y el art. 9,2, además, se ubica en el Título preliminar -donde aparecen aquellas normas y declaraciones que informan todo el resto de la constitución-.

- el art. 3,2 habla de los trabajadores, lo que constituye una velada noción clasista que probablemente ha puesto en guardia a la judicatura italiana.

En cambio, el art. 9,2 español habla de los ciudadanos, denominación feliz por su amplitud $^{234}$.

Así las cosas, el Tribunal Constitucional español ha preferido interpretar materialmente el art. 14 más que enfrentarse directamente con el 9,2. O sea, ha dejado de lado una interpretación puramente formal de la igualdad del art. 14. Entonces, ¿cuáles son los ámbitos propios de ambas normas? ? $^{235}$. La manera de precisar dichos ámbitos pasa por reservar el art. 9,2 "... a aquellos supuestos de desigualdad material cuya corrección, además, comporte la necesidad de provocar un avance social intenso en una determinada zona" ${ }^{236}$. Así, dado que dichas correcciones sociales no son tarea del Tribunal Constitucional, lo que a éste sí le incumbe es hacer "... 'recomendaciones al legislador' dirigidas a recordar a éste la exigencia constitucional de producir ciertas leyes y de producirlas en el sentido más adecuado a la remoción de determinados obstáculos sociales..." ${ }^{237}$. En fin, ayuda también a la precisión de los ámbitos antedichos el reparar en la proyección constitucional del art. 9,2, con un modo y una intensidad de los que carece el art. 14. Esos intentos de precisión no se vislumbran -recuérdese que Garrorena habla en 1984- en el Tribunal Constitucional ${ }^{238}$.

b) Otra consecuencia de la calificación social del estado es la "... 'regulación constitucional del proceso económico y del estatuto de sus principales protagonistas', contenido que, en otro tiempo, hubiera sido inimaginable en el texto de una ley fundamental y que hoy constituye uno de los núcleos de lo que la doctrina alemana define como 'Wirtschaftsverfassung' o 'Constitución económica', categoría esta última que ha tenido ya adecuada recepción en la jurisprudencia de nuestro Tribunal Constitucional..." ${ }^{239}$. Más en concreto:

- se institucionaliza la libertad de empresa en el marco de la economía de mercado (en el art. 38) y, además, se permiten las asociaciones empresariales (en el 7$)^{240}$; y 28$)^{241} ; y$

- se constitucionaliza la libertad para sindicarse y el poder sindical (en los arts. 7

- también se constitucionaliza a un tercer protagonista del proceso económico: el estado. Así, los arts. 40, 130 y 131 "... vienen a reconocer el papel rotundo, expansi-

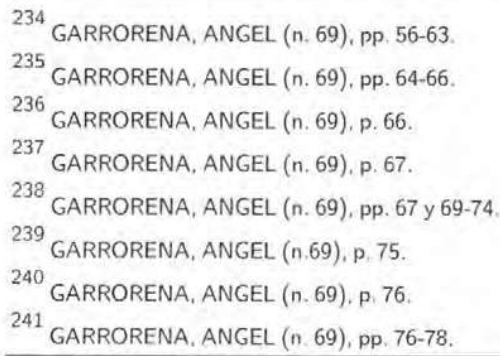


vo, que al Estado compete hoy en la dirección y regulación del proceso económico; protagonismo que es reflejo de esa convicción típica del 'Estado social' según la cual la economía ya no es un sistema espontáneo, perfecto y autorregulado, sino que necesita la constante tutela e intervención del Estado como 'regulador' ${ }^{242}$. Y el art. 128,2, al reconocer la iniciativa pública en materia económica, hace del estado "... no sólo 'regulador' externo del proceso económico, sino también [posible] 'empresario', titular de actividades productivas concretas, convertidas, en su caso, en sector nacionalizado o socializado de la economía del país" ${ }^{243}$.

Ahora bien, el modelo económico de mercado señalado en el art. 38 admite dos lecturas: una conservadora, que verá en él la consagración constitucional de un preciso modelo económico, y otra avanzada, que señalará en él una mera certificación de un dato de la realidad, de un punto de partida desde el cual es perfectamente posible acometer un proceso de transformación (como lo abonarían los arts. 38, al final; 128,$2 ; 9,2$ y 129 ,2). Esto no equivale a afirmar que la constitución española es económicamente neutral, que no se compromete con modelo económico alguno, como lo ha señalado en Alemania el Tribunal Constitucional Federal. La constitución española sí recoge precisamente un modelo, el de la economía de mercado, susceptible -eso sí- tanto de una inteligencia conservadora cuanto de una avanzada ${ }^{244^{\circ}}$.

c) Una tercera consecuencia del estado social es la consagración constitucional de los llamados derechos sociales. En el terreno de las relaciones de producción, aparecen los derechos de sindicación y de huelga (en el art. 28), los derechos a la negociación colectiva y a adoptar medidas de conflicto colectivo (en el art. 37 ) y el derecho al trabajo, tanto en su faz individual (en el art. 35,1 ) como en su dimensión colectiva (en el art. 40,1 ). En el ámbito de la asistencia social, los derechos a la seguridad social (en el 41), a la educación (en el 27), a la vivienda (en el 47), la sanidad (en el 43), la protección del medio ambiente (en el 45), y otros del capítulo tercero del Título I. En lo que toca a la limitación social de derechos clásicos, el caso ejemplar es el de la propiedad (en el art. 33$)^{245}$.

d) Como puede inducirse, "... el Estado encargado de gestionar tales cometidos, sin ocultar por ello la permanencia de su sustrato capitalista, es un Estado cualitativamente diferente: distinto en la doble y complementaria dimensión de su estructura y de sus funciones" 246 . En lo interesante a las funciones estatales, el estado social desarrolla las que siguen:

- una 'función asistencial' en virtud de la cual el estado se hace responsable de servicios y prestaciones, cuyo objeto es procurar las condiciones indispensables para la existencia humana. Gran parte del capítulo tercero del Título I refleja esta función ${ }^{247}$;

\footnotetext{
242 GARRORENA, ANGEL (n. 69), pp. 78-79.

${ }^{243}$ GARRORENA, ANGEL (n. 69), p. 79.

244 GARRORENA, ANGEL (n. 69), pp. 88-99.

${ }^{245}$ GARRORENA, ANGEL (n. 69), pp. 79-82.

${ }^{246}$ GARRORENA, ANGEL (n. 69), p. 83.

${ }^{247}$ GARRORENA, ANGEL (n. 69), pp. 83-84.
} 
- "una 'función de intervención y tutela de la economía', que convierte al Estado en planificador, regulador y aún 'empresario' dentro del proceso económico..." ${ }^{248} ;$ y

- una 'función de remodelación social' por medio de la cual el estado debe acometer la tarea de la transformación de la estructura social. Tal es el sentido del art. 9,2, que, además, vincula a todos los poderes públicos ${ }^{249}$.

En lo relativo a la estructura estatal, el estado social es "... un Estado 'estructuralmente distinto' [del liberal], redoblado en la intensidad de su poder, omnipresente, dotado de una organización y de una burocracia, de un aparato, como jamás se hubiera podido imaginar..." ${ }^{250}$. De ahí que se trate de un estado que abandona la idea de la autonomía y del funcionamiento casi paralelo de la sociedad y del estado; el estado social se funda en la interacción y en la interpenetración entre el estado y la sociedad $^{251}$.

e) Garrorena, finalmente, se pregunta por la eficacia juridica de la cláusula del estado social (del art. 1,1).

"En principio... no es posible vincular a la misma consecuencias jurídicas de exigibilidad inmediata amparadas en este solo precepto... Esto es evidente. Pero sería absolutamente incorrecto deducir de aquí que la calificación del Estado como 'social' carece de valor normativo.... y que su alcance se reduce, en consecuencia, al de una mera declaración constitucional de aspiraciones o principios" ${ }^{252}$. Por el contrario, esta calificación es una norma en los siguientes sentidos:

- es una cláusula con un enorme valor hermenéutico, pues vincula a los poderes públicos y a los ciudadanos en la faena de interpretación de todo el ordenamiento jurídico $^{253}$. En este punto, Stein, en Alemania, ha subrayado dos aspectos: uno, "la posibilidad de acogerse en la interpretación del ordenamiento al pricipio de 'obligación social del Estado', es decir, a la presunción de responsabilidad pública en materia de prestaciones sociales", y dos, "la inclinación a establecer una "conexión o modulación social de los derechos fundamentales'...", reforzando el disfrute efectivo de los derechos por parte de los menos favorecidos y restringiendo el alcance de esos derechos por parte de los privilegiados ${ }^{254}$.

- aunque esta cláusula, por sí misma, es incapaz de fundar una pretensión juridica inmediata, sí puede hacerlo cuando concurra con otras normas. Así, de hecho han habido pretensiones basadas en la interacción de los arts. 1,$1 ; 9,2$ y $14^{255}$.

- en lo que dice relación con el recurso de inconstitucionalidad de la ley, la cláusula del estado social alcanza una eficacia accionable. En efecto, en virtud de los arts.

\footnotetext{
${ }^{248}$ GARRORENA, ANGEL (n. 69), pp. 84-85

${ }^{249}$ GARRORENA. ANGEL (n. 69), pp. 86-87

${ }^{250}$ GARRORENA, ANGEL (n. 69), p. 87

2.51 GARRORENA, ANGEL (n. 69), p. 87

252 GARRORENA, ANGEL (n. 69), pp. 99-100.

253 GARRORENA, ANGEL (n. 69), p, 101.

254 GARRORENA, ANGEL (n. 69), pp, 101-102

${ }^{255}$ GARRORENA, ANGEL (n. 69), pp. 102-103.
} 
32,1 y 35 y siguientes de la Ley Orgánica del Tribunal Constitucional, esta cláusula deviene derecho inmediatamente aplicable en este procedimiento ${ }^{256}$. Es, verdaderamente, una norma: "... desde la misma es posible actuar pretensiones de neta 'eficacia impeditiva', esto es, es posible anular o 'impedir' la obra del legislador que no se adecúe al compromiso social adquirido por el Estado en el nuevo texto constitucional"257.

- la jurisdicción constitucional, por último, posee una eficacia negativa (pues frena el derecho inconstitucional), mas no positiva (ya que no puede vincular al legislador para que produzca un cierto derecho). Puede, sí, acercarse a esta eficacia positiva:

* a través de las recomendaciones al legislador;

* a través de la declaración de inconstitucionalidad de situaciones que sólo son 'lícitas' porque el legislador no las ha proscrito con una ley de contenido 'social'; y

* a través de la censura de la pasividad del legislador, de la fijación (a éste) de un plazo para que actúe y de la declaración de que el legislador ha violado la constitución si persiste en su pasividad ${ }^{258}$.

\subsection{Los elementos del estado social de derecho}

Al finalizar, puede constatarse que el estado social de derecho todavía es un concepto impreciso. Aunque hay alguna similitud en los autores y en las constituciones acerca de su perfil, su contorno no posee mayor nitidez. Por eso es por lo que se ha hablado sólo de la formación del estado social, y no de su constitución-como sí se hizo con el estado de derecho-. Así, por ejemplo, no hay mayor nitidez en torno a la responsabilidad que tiene el estado por el conjunto de sus objetivos y tareas 'sociales'; correlativamente, tampoco la hay en lo que toca a la verdadera naturaleza jurídica de los derechos 'sociales' y a su accionabilidad judicial. Y en cuanto al tribunal constitucional, ocurre otro tanto: su papel en un estado social puede ser sumamente importante -es cosa de avaluar la importancia que tiene una recomendación al legislador o, más aún, la declaración de que éste ha violado la constitución-, pero es un tribunal especialísimo que ni siempre existe ni siempre cumple igual papel en dicho estado.

Sí puede decirse que el estado social se funda en el estado de derecho, por lo cual los elementos de éste son también elementos de aquél. Es decir, en un estado social de derecho, para que sea tal, ha de haber sujeción del poder público a la ley-de lo que deriva el control y la responsabilidad del poder público-, división de este poder en diversos órganos, garantía de los derechos del individuo, acceso al poder por elección (mediando el sufragio universal y primando la decisión de la mayoría) y pluralismo en cuanto a las ideas y a las agrupaciones. De todos modos, el estado de derecho recibe distintas modulaciones por parte del estado social y de la sociedad contemporánea basta recordar estas modulaciones en Justo López, Belmar y García-Pelayo-.

\footnotetext{
${ }^{256}$ GARRORENA, ANGEL (n. 69), p. 103.

257 GARRORENA, ANGEL (n. 69), p. 104.

258

GARRORENA, ANGEL (n. 69). pp. 104-106. Como se ve, la última de las maneras de acercarse a la eficacia positiva es la que señala Schneider, y que se expuso al analizar la Ley Fundamental de Bonn.
} 
Con estas prevenciones, es posible entregar los siguientes elementos del estado social de derecho:

a) se trata de un estado que debe planificar y participar del proceso económico sobretodo redistribuidoramente- e intervenir en la configuración de la sociedad sobretodo igualadoramente-, con el objeto de procurar, en especial a la población más carente, las condiciones indispensables para el desarrollo material y cultural de la vida humana; $y$

b) parejamente, supone el reconocimiento de derechos sociales, económicos y culturales del hombre, por un lado, y de la función social de variados derechos individuales -sobretodo el de propiedad privada-, por el otro.

\subsection{La crítica al estado social de derecho}

Para terminar, hay que apuntar que la idea y la realidad del estado social han recibido numerosas objeciones durante los últimos años. Con el puro fin de ilustrar, se muestra brevísimamente la crítica realizada por Cortina, una convencida partidaria de esta forma estatal ${ }^{259}$.

Cortina piensa que el estado social expresa y defiende no una ciudadanía simplemente civil o política, sino una verdadera ciudadanía social, cauteladora de los derechos sociales de mujeres y hombres. Tal estado social, empero, admite al menos dos formas de realización. Una, reprochable y fracasada, es la del estado de bienestar, que remonta a Bismarck, a la escuela histórica alemana y a la Verein für Sozialpolitik, a Pareto, a Pigou y a la Welfare-Theorie, a Keynes y al Informe Beveridge. Es el estado de la 'solidaridad institucionalizada', cuyos productos son el paternalismo, el intervencionismo, la compra de votos, el electorerismo y el megaestado. Para Cortina, como es obvio, el estado de bienestar ha de terminar, ya que acabó por perder su justificación económica. Por el contrario, el estado social tiene que permanecer y ser asegurado, pues los derechos de la segunda generación no deben perderse, sino más bien gestionarse correctamente.

Es indispensable, pues, para Cortina, consagrar realmente un estado social de justicia. Tal estado representa una exigencia ética, dado que defiende los mínimos de justicia imprescindibles para toda sociedad humana. A este estado no le incumbe ni el bienestar (que cada cual debe pagar de su peculio) ni la solidaridad (que le toca a la sociedad civil); sí le corresponde reactivar la riqueza y la productividad, erradicar la pasividad, la heteronomía y la dependencia y proteger la libertad y la igualdad. De la mano de la afirmación kantiano-cristiana de que toda persona es un fin y tiene dignidad y de que deben protegerse los derechos cívicos y sociales de todos, Cortina dice que el estado social (y también la economía social de mercado propugnada por la socialdemocracia y por la doctrina social de la Iglesia) prescribe tratar a los seres humanos como ciudadanos, en todo el sentido de la palabra, de manera que puedan identificarse como tales. 